\title{
Short-term late Holocene dry season occupation and sandy-mud flat focused foraging at Murdumurdu, Bentinck Island, Gulf of Carpentaria
}

\author{
Robin W. Twaddle ${ }^{\mathrm{a}, \mathrm{b}}$, Craig R. Sloss ${ }^{\mathrm{c}}$, Kelsey M. Lowe ${ }^{\mathrm{d}, \mathrm{e}}$, Patrick Moss ${ }^{\mathrm{e}}$, Lydia L. \\ Mackenzie ${ }^{\mathrm{e}, \mathrm{f}}$ and Sean Ulmª, \\ a ARC Centre of Excellence for Australian Biodiversity and Heritage, James Cook University, PO Box 6811, Cairns, QLD \\ 4870, Australia; ${ }^{b}$ College of Arts, Society and Education, James Cook University, PO Box 6811, Cairns, QLD 4870, \\ Australia; ' School of Earth, Environmental and Biological Sciences, Queensland University of Technology, GPO Box 2434 ,

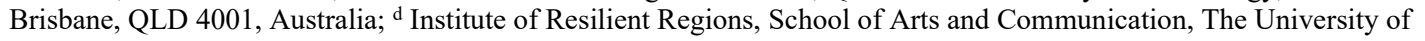 \\ Southern Queensland, Toowoomba, QLD 4350, Australia; ${ }^{\mathrm{e}}$ School of Earth and Environmental Sciences, The University of \\ Queensland, Brisbane, QLD 4072, Australia; ${ }^{\mathrm{f}}$ State Key Laboratory of Lake Science and Environment, Nanjing Institute of \\ Geography and Limnology, Chinese Academy of Sciences, Nanjing 210008, China \\ * Corresponding author sean.ulm@jcu.edu.au
}

\begin{abstract}
Archaeological survey, excavations, and analyses of the Murdumurdu shell midden on Bentinck Island, Gulf of Carpentaria are reported. Patterns of subsistence as well as the timing and periodicity of site use are investigated through quantification of cultural materials, AMS radiocarbon dating, stable isotopic analysis of Marcia hiantina shell carbonates $\left(\delta^{18} \mathrm{O}\right.$ and $\left.\delta^{13} \mathrm{C}\right)$, magnetic susceptibility analysis of the deposits and palaeoenvironmental reconstruction. Exploitation of shellfish focused on sandy-mud flat species (especially M. hiantina and Gafrarium pectinatum) with occupation occurring exclusively during the dry season (May-August). Radiocarbon dating reveals that the main period of occupation was short, albeit intense and occurred c.300 years ago. Initiation of occupation closely follows the establishment of freshwater conditions in the adjacent Marralda Swamp. These factors suggest that use of Murdumurdu was limited, potentially representing a single deposition event or multiple short, discrete episodes, in a landscape rich with similar archaeological deposits.
\end{abstract}

\section{Introduction}

Archaeological investigations at Murdumurdu were undertaken as part of a wide-ranging archaeological and palaeoenvironmental study of the South Wellesley Archipelago (Memmott et al. 2016; Ulm et al. 2010). These studies demonstrate that while there is evidence for Aboriginal occupation of the South Wellesley islands by around 3500 years ago, a continuous occupation signal does not occur before c. 2000 years ago and by 1500 years ago a range of sites are in use (Memmott et al. 2016; Ulm et al. 2010). A broadly similar occupation history is documented for the larger Mornington Island in the North Wellesley Islands, albeit with a more limited sample size (Rosendahl et al. 2014a). There is distinct acceleration in the creation and use of sites from 700 years ago, accelerating further in the last 300 years. This paper describes the Murdumurdu site and its environmental and palaeoenvironmental context, stratigraphy, chronology and contents followed by a discussion of the foraging behaviours, and occupation patterns employed by site users.

\section{Site Description and Setting}

Murdumurdu (also Ḿodomodo, Modomodo) is a large stratified low density shell midden located on the south coast of Bentinck Island (Latitude: $17.09746^{\circ} \mathrm{S}$, Longitude: $\left.139.54625^{\circ} \mathrm{E}\right)$. Murdumurdu was recorded during pedestrian transect surveys in 2012 and subsequent palaeoecological investigations at the nearby Marralda Swamp (see Mackenzie 2016; Mackenzie et al. 2017; Moss et al. 2015). The site is one of a number of surface shell exposures documented along the low coastal dunes between Jirrkamirndiyarrb and Mirdidingki Creek (Figures 1-2).
Surface shell exposures at Murdumurdu encompass an area of approximately $3000 \mathrm{~m}^{2}$, situated c. $10 \mathrm{~m}$ to $20 \mathrm{~m}$ south of Marralda Swamp on a series of low prograding coastal dunes that separate the swamp from the modern coastline c. $150 \mathrm{~m}$ to the south. Murdumurdu is contained in an east-west oriented beach ridge bordering the swamp, with its northern margin terminating at the swamp. The ridge appears well stabilised and the surface does not appear deflated. No surface shell is visible in the area except for in the spoil of a large goanna (Varanus spp.) burrow, where whole valves of Marcia hiantina and a silcrete artefact are visible, and occasional shell material in cane toad (Rhinella marina, syn. Bufo marinus) burrow spoil. Large broad-leaved paperbark (Melaleuca quinquenervia) trees line the bank of the swamp, with reeds near the bank and open standing freshwater beyond (see Moss et al. 2015:Figure 3).

At present, Marralda Swamp comprises a series of interconnected wetland channels containing permanent freshwater to a depth of up to $150 \mathrm{~cm}$. The swamp occupies the inter-dune swales of the coastal dune field $1 \mathrm{~m}$ to $3 \mathrm{~m}$ above present mean sea-level (PMSL) and connects with Mirdidingki Creek c.500m to the west and a clay pan to the east (Figure 2). Vegetation comprises open coastal woodland with Pandanus spiralis, Melaleuca acacioides (coastal paperbark) and a mixed grassland including Spinifex longifolius surrounding the site with Eleocharis dulcis and Typha sp. growing in the wetland (Mackenzie et al. 2017). The spike-rush corms of E. dulcis were a key subsistence resource in the past and are known in the Kaiadilt language (Kayardild) as damuru (see Evans 1992:88).

As part of related geomorphological studies, transects of augers and trenches across the beach ridge system were undertaken. The Marralda Swamp beach ridge system 
comprises 10 individual ridges and extends $900 \mathrm{~m}$ inland, with an elevation of $3 \mathrm{~m}$ to $8 \mathrm{~m}$ and an average elevation of $5 \mathrm{~m}$ above PMSL. Three main facies were identified (O'Connor 2016) (Figure 2):

1. A basal unit comprising rounded, medium-to-coarsegrained, moderately-sorted mixed siliciclastic and carbonate sand, dated to c.5000 cal BP. Low-angled seaward dipping planar beds were observed in section, often defined by interbedded densely-packed shell beds, shell hash and pisoliths. The facies is interpreted as a beach-face within the beach ridge system.

2. Overlying the basal unit is a fine-to-medium-grained, moderately-sorted siliciclastic quartz sand with a minor component of carbonate shell fragments, dated to c. 3500 to $300 \mathrm{cal}$ BP. Subhorizontal to very low angled landward dipping planer bedding were observed in trench and pits. The facies is interpreted as a reworked back-beach deposit.

3. The upper-most facies comprise a well-rounded, wellsorted quartz sand, with common to present pisoliths, dated to the last 300 years. Grains are well-frosted and iron-stained indicating reworking and subaerial exposure. Shell fragments are present and whole valves rare to present and heavily weathered. The facies is interpreted as the aeolian capping of the beach ridge system. Archaeological materials have only been observed in this upper-most unit.

Beach ridge systems at Marralda show a general age progression from the older landward dunes to the younger seaward dunes with results indicating an initial phase of dune building associated with the culmination of the most recent post-glacial marine transgression c.6700-6000 cal BP. Increased sediment supply, combined with elevated sea-levels of between 1.5 and $2 \mathrm{~m}$ above PMSL, resulted in progradation of elevated beach ridges (for similar conclusions from elsewhere in the Gulf of Carpentaria, see Lees 1987; Lees et al. 1990; Shulmeister and Lees, 1992). Results indicate a potential hiatus in coastal progradation between 3000 and 1900 cal BP associated with a decline in precipitation and increased climate variability after 3700 cal BP (Lees 1987; Lees et al. 1990; Shulmeister and Lees 1992) with reduced sediment transport to the area. Results indicate a more recent phase of dune formation and coastal progradation from 1900 cal BP, consistent with palynological research showing coastal wetland development and mangrove expansion since 1250 cal BP (Mackenzie 2016; Moss et al. 2015).

Palynological analysis of a core extracted from Marralda Swamp indicates that a well-established mixed mangrove forest dominated by Rhizophora sp. was present in the swamp between 1250 and 850 cal BP (Mackenzie 2016; Mackenzie et al. 2017). Mangrove taxa declined after $900 \mathrm{cal}$ BP as aquatic taxa increased, indicating a transition to a brackish/freshwater wetland by c. 800 cal BP. Woodland taxa increased from 850 cal BP and Rhizophora sp. declined further at $400 \mathrm{cal} \mathrm{BP}$, with freshwater aquatic and woodland species increasing, indicating the final phase of freshwater swamp development. An increase in macroscopic charcoal between 350 and 150 cal BP suggests a larger area was burned around Marralda Swamp, with microscopic charcoal reflecting an increase in regional fire activity since AD 1950 (Mackenzie 2016).

Long expanses of sandy beaches with occasional she-oak (Casuarina equisetifolia) trees positioned along the strandline typify the southern coastline, while the exposed dune system supports savanna grasses (Figures 3-4). Intertidal sandy-mud flats along the sheltered shoreline adjacent to the site support hiant venus clams ( $M$. hiantina) and tumid venus clams (Gafrarium pectinatum), which dominate the midden. The shallow and sheltered waters in this area provide ideal conditions for seagrass beds, which attract fish and dugong. A number of relict coral reef platforms are situated within $500 \mathrm{~m}$ of the site near a shallow sand-spit that, when exposed at very low tide, can be used to cross to Fowler Island on foot. Rocky areas support clumps of top snails (Calliostoma sp.) and oysters. Mirdidingki Creek to the west is a small tidal estuary that supports thick stands of mangrove vegetation, hosting populations of Geloina expansa, Telescopium telescopium, and Nerita sp.

The area of Murdumurdu was mapped by Norman Tindale (1962a) as Ḿodoḿodo, one of many named camping sites and cultural places along this stretch of coastline. Roth (1901, 1903) also appears to have visited the area on each of his trips in 1901, 1902 and 1903 (see Jackson 1902). In the winter of 1901, Roth describes encountering recently-vacated Kaiadilt campsites at an area with a 'billabong' and 'lagoons':

[We] came upon a camp which had evidently, from the condition of the fires, \&c., been occupied the night before. As this was similar to several subsequently examined, I may describe it now. Each one's quarters consisted of a circular space, about $4 \mathrm{ft}$. wide, dug to a depth of 6 in. or so in the sand, that half of the border exposed to the prevailing winds supporting a "break-wind". This was composed of bundles of long grass, tied up like sheaves, each bundle being placed lengthways, one on top of the other, to a height of about $2 \mathrm{ft}$. Each native had evidently been sleeping in the curled position, with his back protected by the grass, and his front warmed by the fire kindled in the centre of the circle. Although winter time, there was not the slightest sign of any switch framework, or bark covering. As further illustrative of the primitive condition of these people, the scybala were found strewn and lying exposed in the immediate vicinity, even inside the circular camping places; their examination showed that at the present time the Pandanus forms the stable vegetable food.

There is limited evidence for recent activities in the vicinity of the site. Occasional vehicle tracks are visible running east-west across the coastal dunes to the immediate south of Murdumurdu and a small cemetery containing two historic Kaiadilt burials is located c. $300 \mathrm{~m}$ to the eastsoutheast. The area is regularly burned by Kaiadilt traditional owners. A partially buried black plastic water pipe runs across the base of the most northerly swale before the swamp. This pipe is related to the former use of Marralda Swamp as a water source supplying the outstation of Nyinyilki c. $2.3 \mathrm{~km}$ to the west-northwest. The surface in the area immediately around the pipe exhibits a discontinuous scatter of shell indicating the presence of subsurface deposits exhumed when the trench for the pipeline was excavated. 

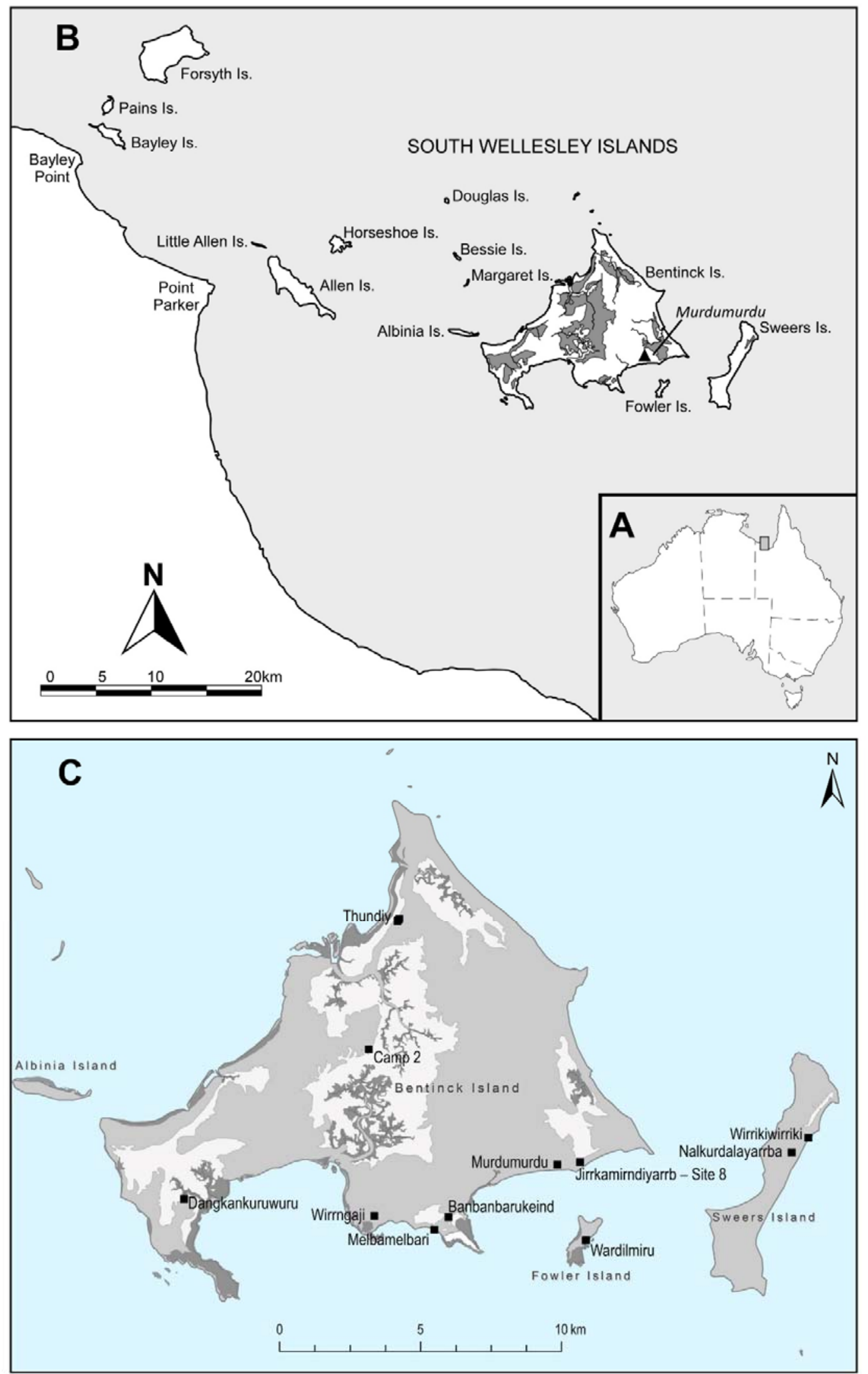

Figure 1. (A-B) The South Wellesley Islands, southern Gulf of Carpentaria, Australia, showing the location of Murdumurdu on the south coast of Bentinck Island. Dark shading shows distribution of claypans. (C) Bentinck Island showing the location of Murdumurdu in relation to other excavated archaeological sites (squares). White shading shows distribution of claypans. 

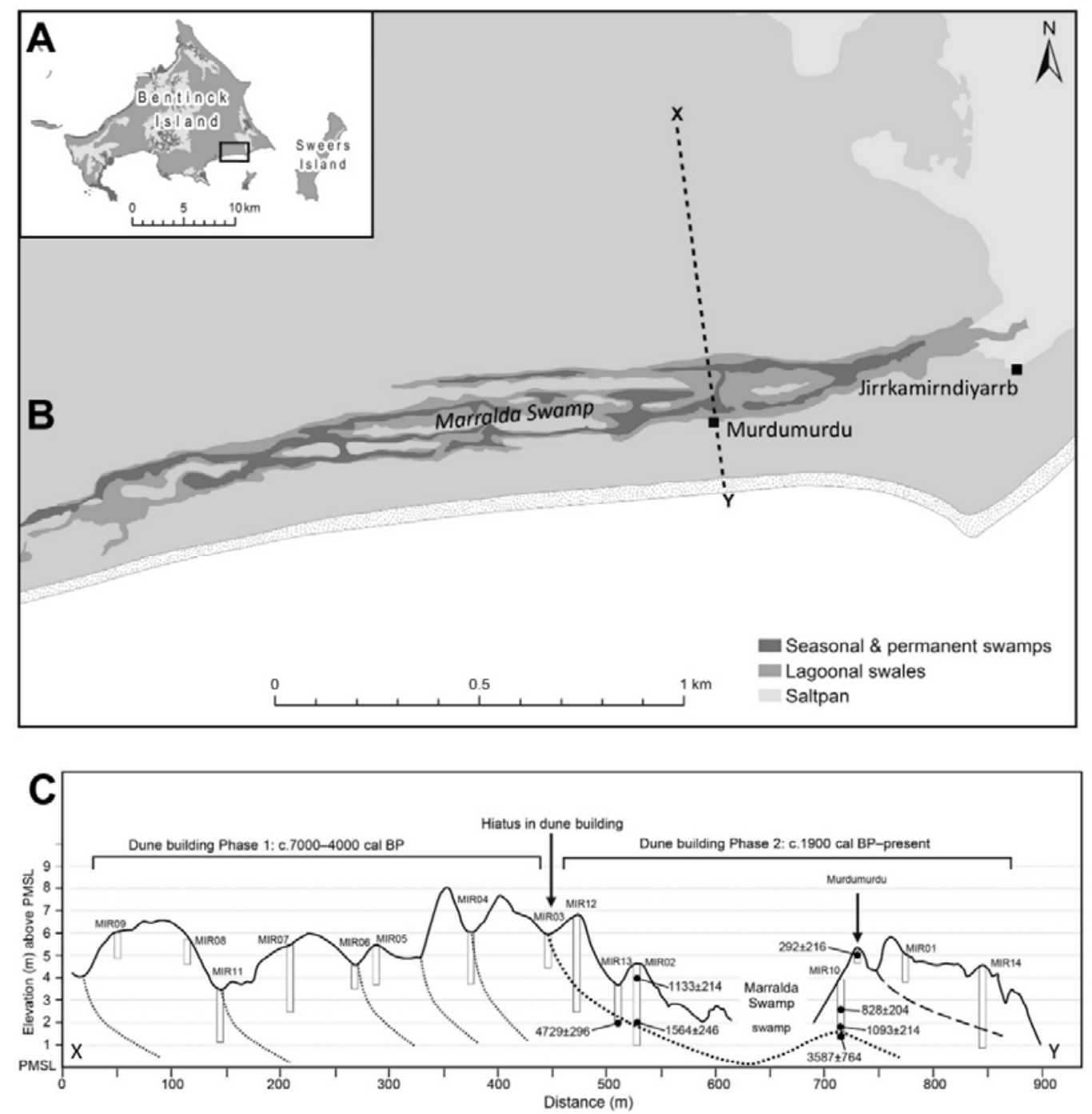

Figure 2. (A-B) Bentinck Island showing the location of Murdumurdu and the Marralda Swamp on the south coast of Bentinck Island. (C) Representative cross-section (X-Y as shown on B) composite stratigraphic section of coastal beach ridge system, showing calibrated radiocarbon dates mean $\pm 2 \sigma$ (after O'Connor 2016). Elevations relative to Australian Height Datum (AHD).

\section{Excavation Methods}

Two $50 \mathrm{~cm} \times 50 \mathrm{~cm}$ excavations (Squares A and B) were undertaken between 13 and 16 July 2012. Squares were positioned at an interval of $10 \mathrm{~m}$ along the crest of a low eastwest orientated ridge bordering Marralda Swamp in the Murdumurdu midden (Figures 3-5). Excavations proceeded in shallow, arbitrary excavation units (XUs) within stratigraphic units (SUs) averaging $3 \mathrm{~cm}$ in depth and $12 \mathrm{~kg}$ in weight, ceasing in culturally sterile sediments $\mathrm{c} .61 \mathrm{~cm}$ and c. $60 \mathrm{~cm}$ below ground surface in Squares $A$ and B, respectively. $\mathrm{pH}$ readings and Munsell Soil Color ${ }^{\circledR}$ Chart tests were completed in the field on dry sediments from each XU. Sediment samples were collected from each XU from the material that passed through the $2.3 \mathrm{~mm}$ sieve. A local site datum was established with a $6 \mathrm{ft}(182 \mathrm{~cm})$ silver galvanised star picket located $7 \mathrm{~m}$ south of the mid-point between Squares $\mathrm{A}$ and B. Five elevations (four corners and centre-point) were recorded at the beginning and end of each excavation unit, using an autoset level and stadia rod. Plan view photographs were taken at the completion of each excavation unit. Section drawings and photographs were made of all sides of every pit after cleaning at the end of the excavation. In addition, photographs were regularly taken to record the excavations in progress and the general site context. A Real Time Kinematic (RTK) surveying system was used to map the site area.

A total of $485.2 \mathrm{~kg}$ of material was removed from the two squares. Magnetic susceptibility samples were taken using Althor P-15 plastic (non-magnetic) boxes (5.28 cc volume) down the south section of Square A and north section of Square B. Shell for radiocarbon dating was removed from the sections of Squares A and B after photographing, drawing and plotting. Groups of three shell valves were sampled from the densest shell deposits in each section in each square for radiocarbon dating. All midden materials were dry-sieved through $2.3 \mathrm{~mm}$ mesh on site. Materials retained in the sieve were double-bagged for laboratory sorting, identification, and analysis. During the excavation of Square A, XU7 a small area at the top of the north profile collapsed, extending from c. $10 \mathrm{~cm}$ to $35 \mathrm{~cm}$ along the surface from the northwest corner and tapering to a depth of $20 \mathrm{~cm}$ below ground surface. Collapsed material was carefully removed before excavation continued to prevent contamination of in situ deposits. 


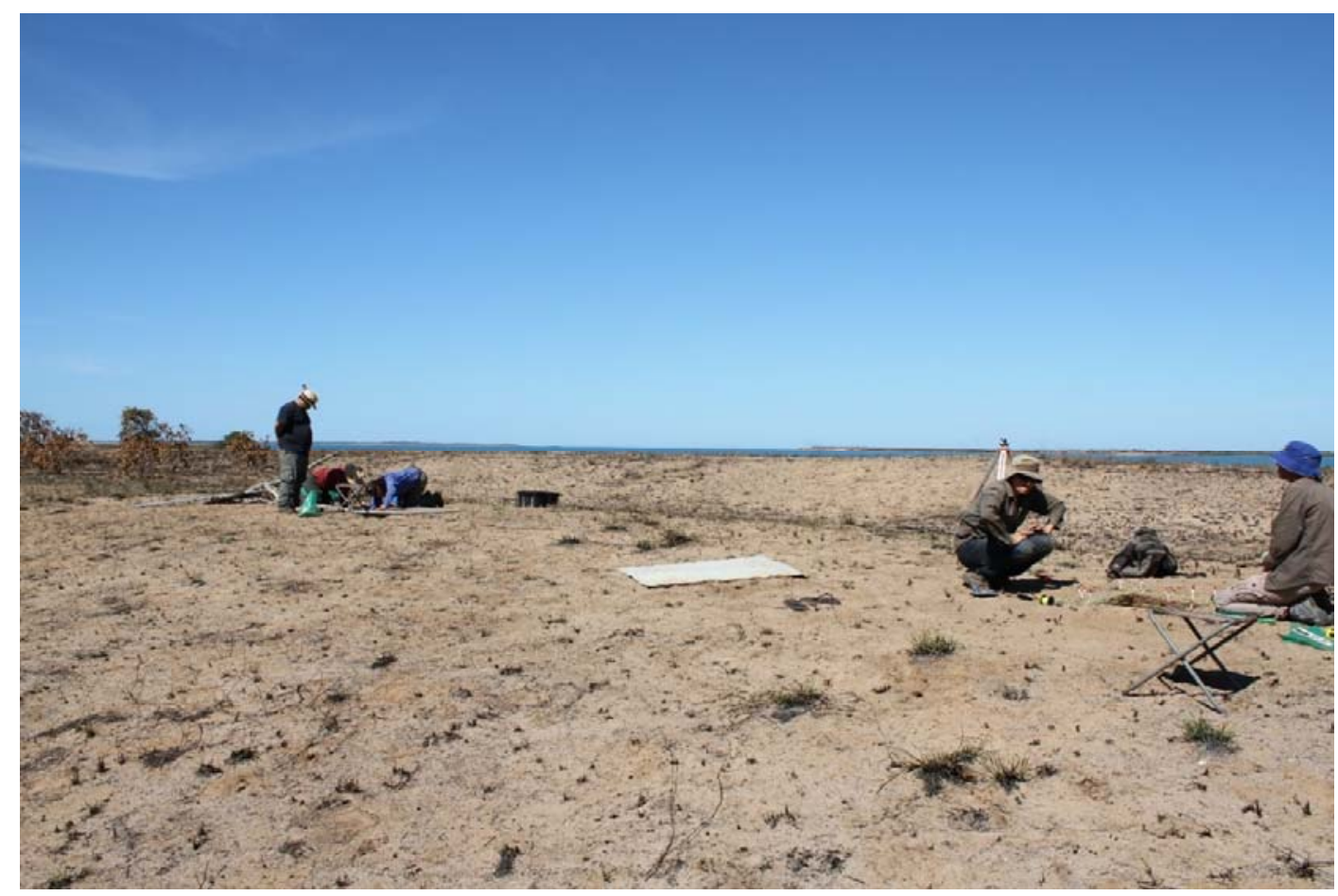

Figure 3. General view of Murdumurdu across low dunes towards the ocean, showing Sweers Island and Fowler Island in the background, facing southeast (Photograph: Daniel Rosendahl, 2012). Note photograph taken after firing by Kaiadilt traditional owners.

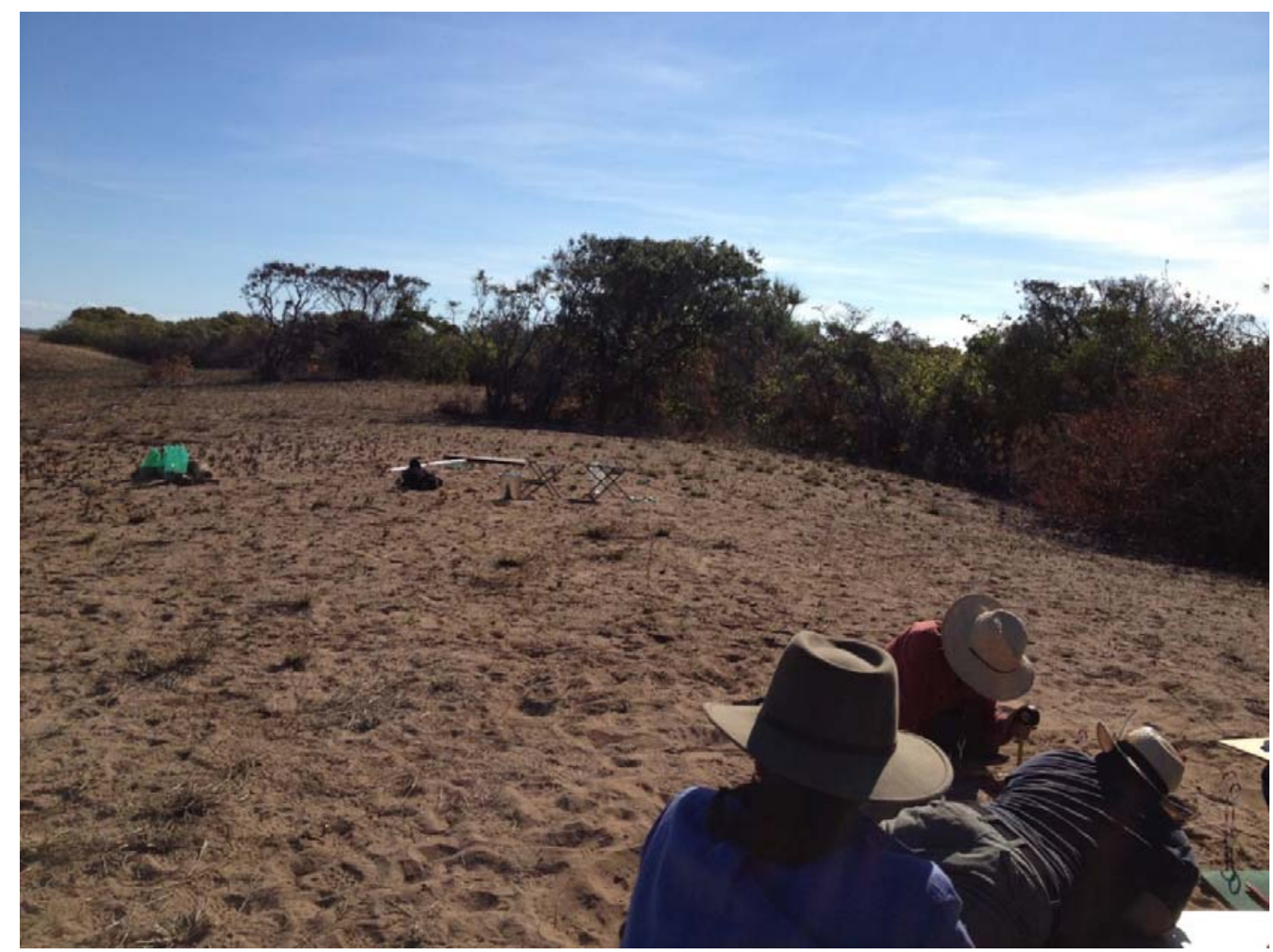

Figure 4. General view of Murdumurdu towards Marralda Swamp, showing excavations in progress (Square A in foreground), facing west-northwest (Photograph: Annette Oertle, 2012). 


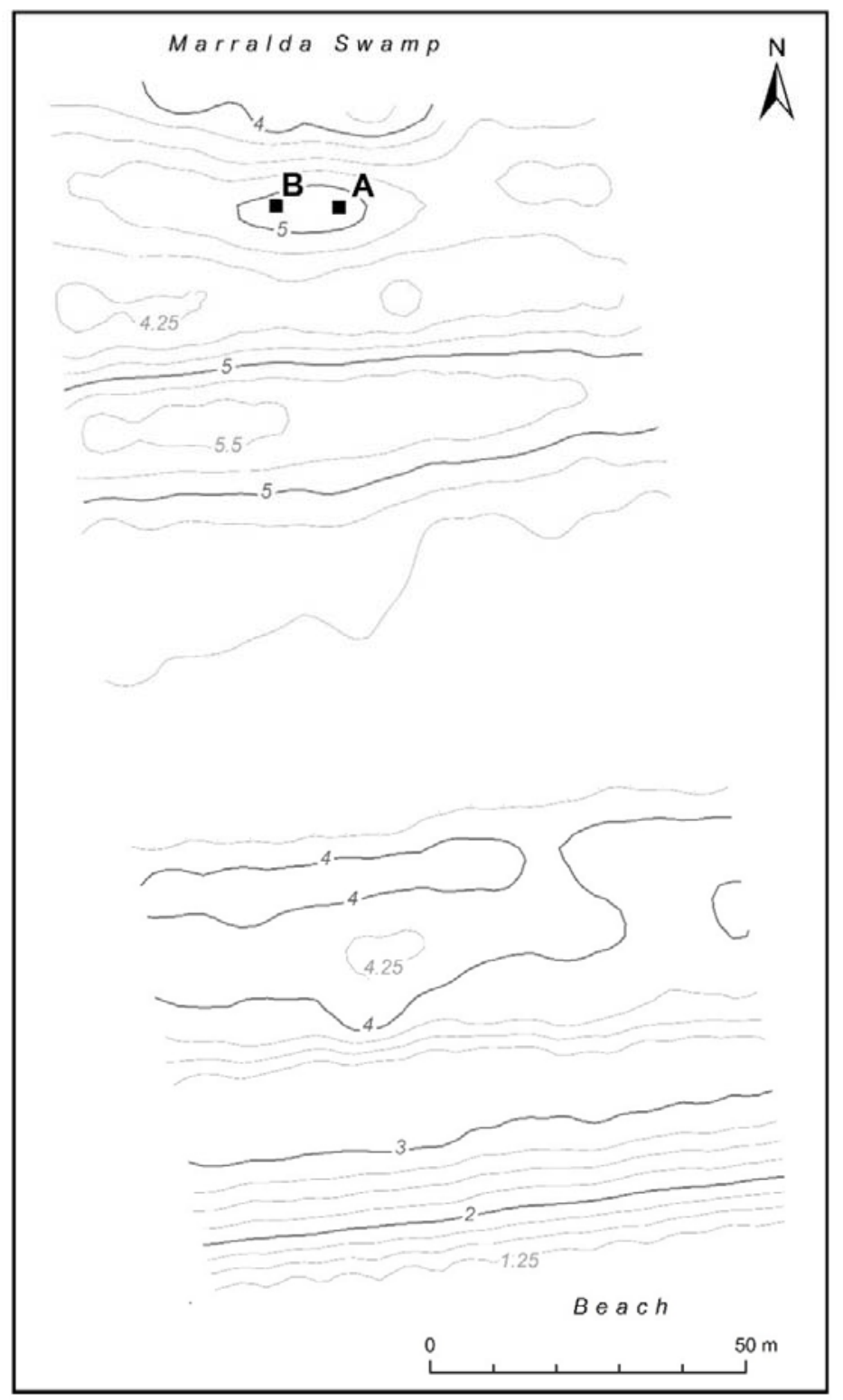

Figure 5. Topographic map showing location of Murdumurdu, Squares A and B in relation to the coastline and Marralda Swamp (Map: Lincoln Steinberger and Sean Ulm, 2012). Elevations relative to Australian Height Datum (AHD).

\section{Cultural Deposit and Stratigraphy}

Excavations revealed a $30-40 \mathrm{~cm}$ thick deposit of reasonably dense cultural materials with shell, bone, and charcoal, resting on degraded beach sands (Figures 6-9). The majority of shell was recovered from Square A between XU3 and XU7 (c.6$22 \mathrm{~cm}$ depth) and in Square B from XU3 to XU8 (c.6.5$24.5 \mathrm{~cm})$. The deposit can be divided into four stratigraphic units (SUs) - from the top, a disturbed layer of humic, coarse brown sands, a cultural unit, and finally a transitional unit overlying a beach base (Figures 10-11; Table 1). SUIa includes materials located between XU1 and XU3 in both Squares A and B. SUIb contains cultural materials between XU4 and XU8 (Square A) and XU4 and XU10 (Square B). SUII contains sparse quantities of cultural materials. SUIII is the beach base and appears to be culturally sterile. Only small shells and shell fragments were recovered below XU10 $(\mathrm{c} .31 \mathrm{~cm})$ in both squares. Lower excavated deposits are likely to reflect non-cultural depositional processes.
There is a predictable shell decay profile with highly weathered tiny gastropod specimens recovered from the lower XUs of the deposit and relatively well-preserved specimens from the upper deposit. There is a pattern of low shell fragmentation (c.120 fragments per $100 \mathrm{~g}$ of shell) contributing to high rates of identification in the upper units that correlates with the period of cultural deposition (see Hoffman 2011). This contrasts with higher shell fragmentation (c.850 fragments per $100 \mathrm{~g}$ of shell) and consequently low rates of identification in deeper and older units. Identification of vertebrate remains was hampered owing to the heavy fragmentation of bones throughout the deposit. The top $10 \mathrm{~cm}$ of both squares is heavily bioturbated by insect burrows and grass roots, indicating minor taphonomic disturbance of the midden. Therefore, small quantities of cultural shell fragments may have filtered through the transition unit. 


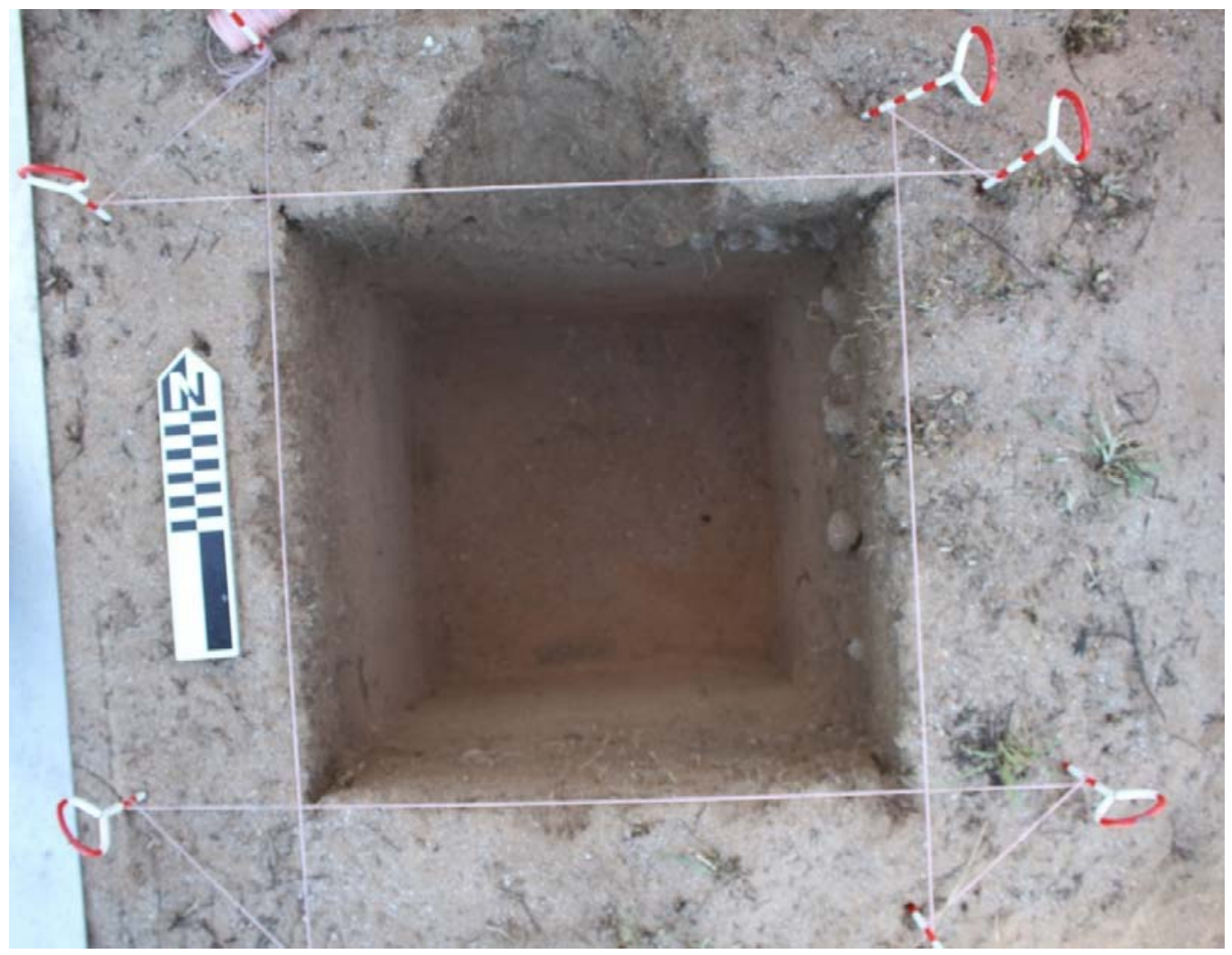

Figure 6. Murdumurdu, Square A at end of excavation, facing north. Note the small collapse in the north section and dense lens of $M$. hiantina visible in the north and east sections (Photograph: Sean Ulm, 2012).

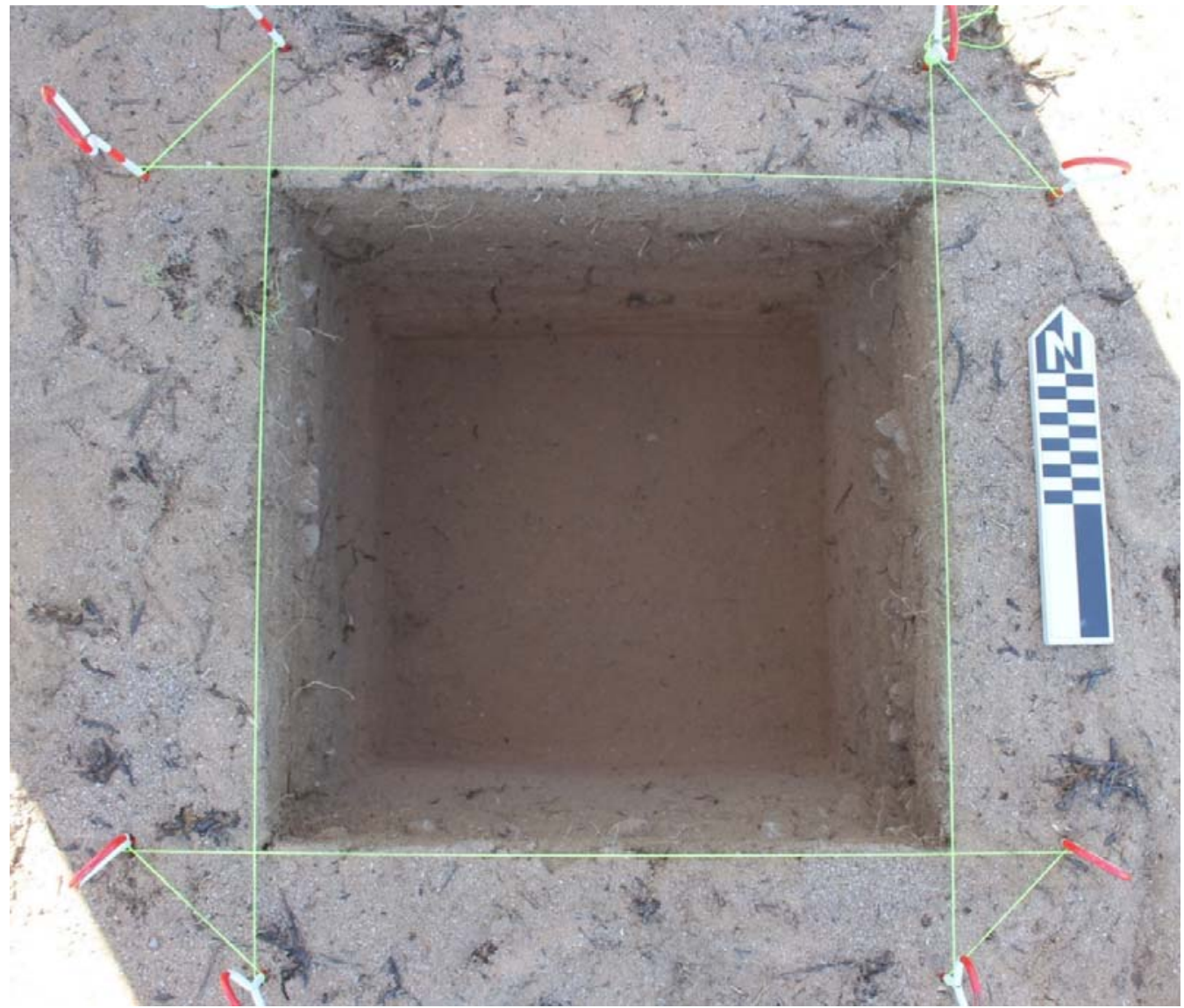

Figure 7. Murdumurdu, Square B at end of excavation, facing north. Note the dense lens of M. hiantina visible in the east, west, and south sections (Photograph: Daniel Rosendahl, 2012). 


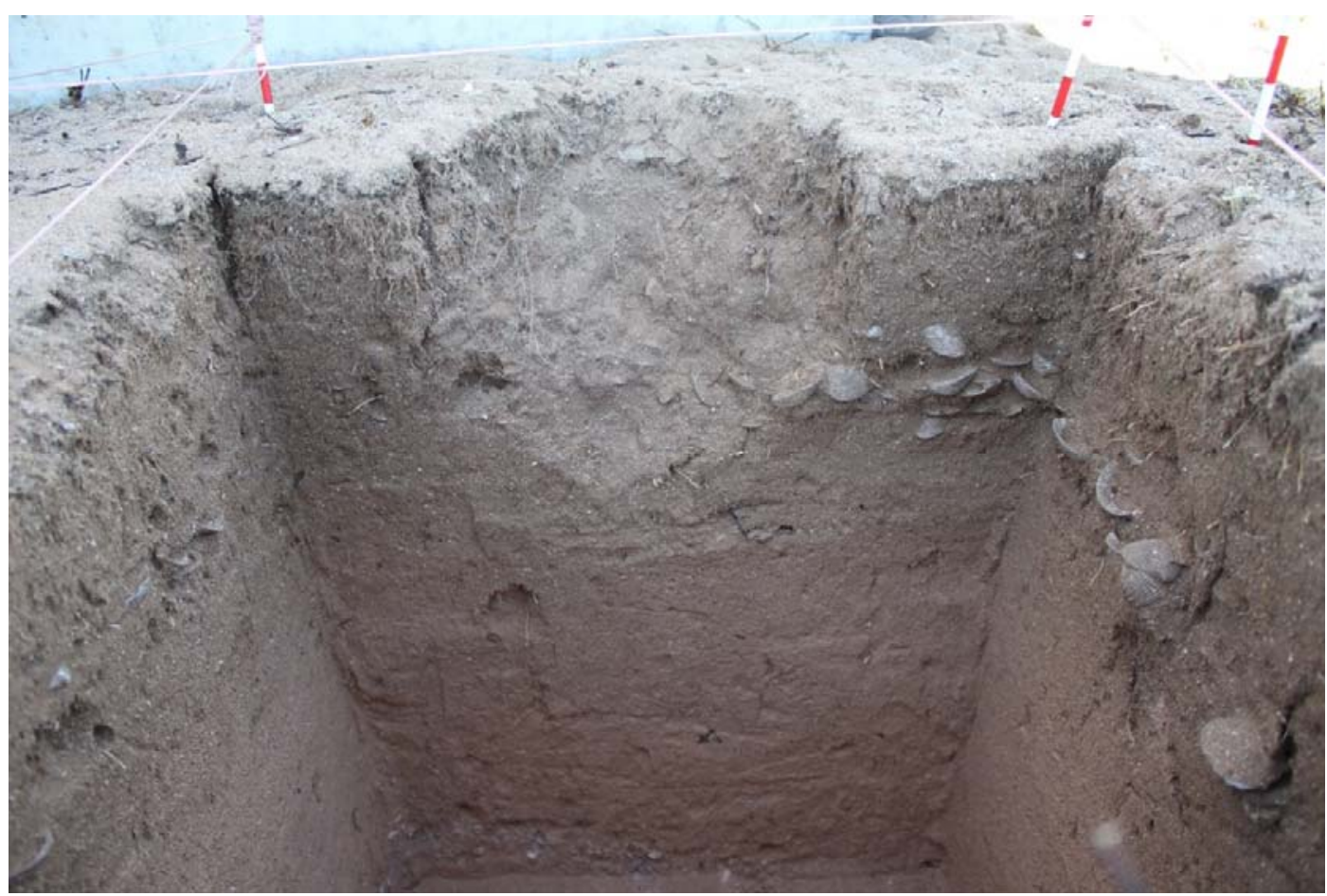

Figure 8. Murdumurdu, Square $A$ at end of excavation, facing north. Note the small collapse in the north section and dense lens of M. hiantina visible in the north and east sections (Photograph: Sean Ulm, 2012).

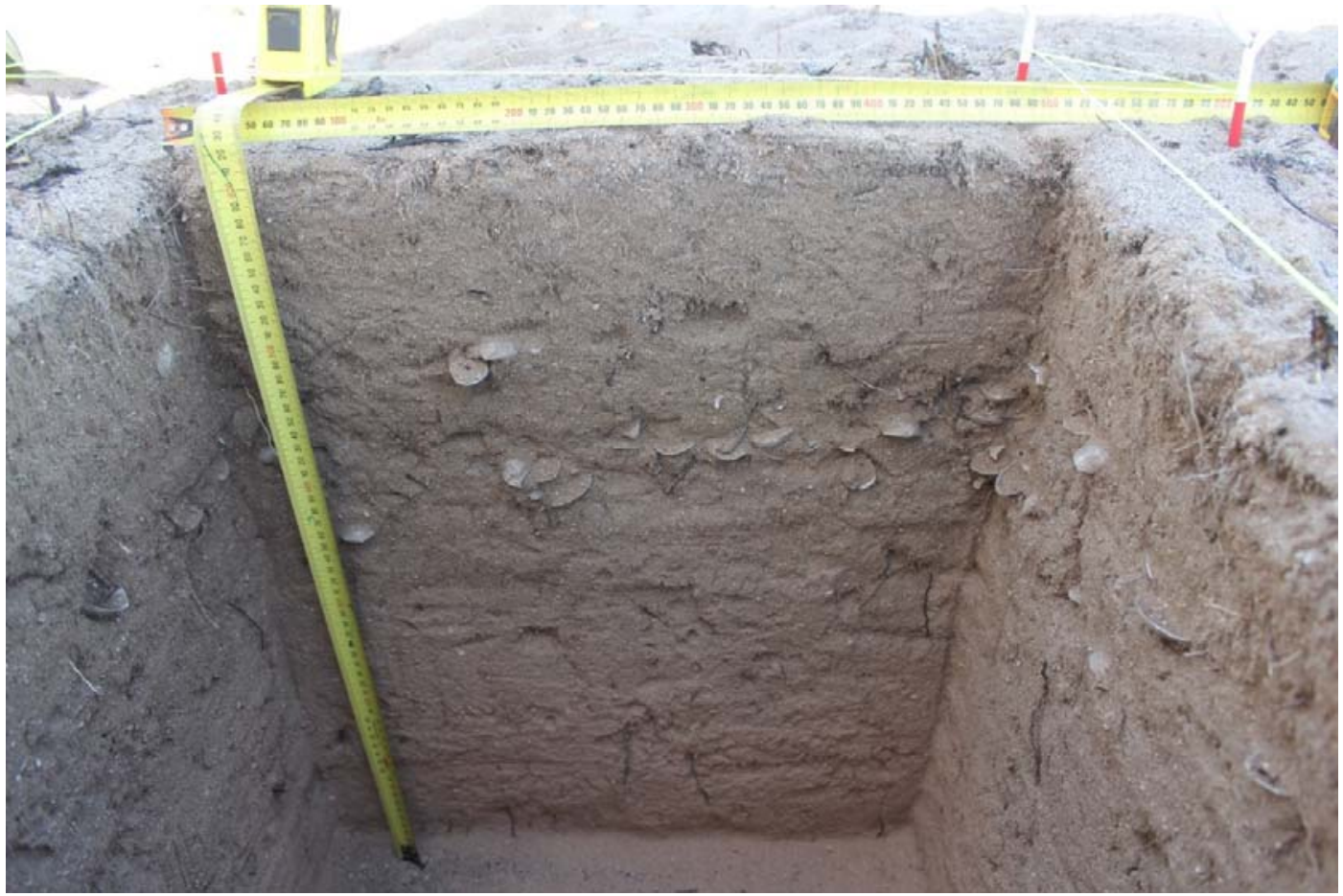

Figure 9. Murdumurdu, Square B at end of excavation, facing east. Note dense lens of $M$. hiantina visible in the north and east sections (Photograph: Daniel Rosendahl, 2012). 


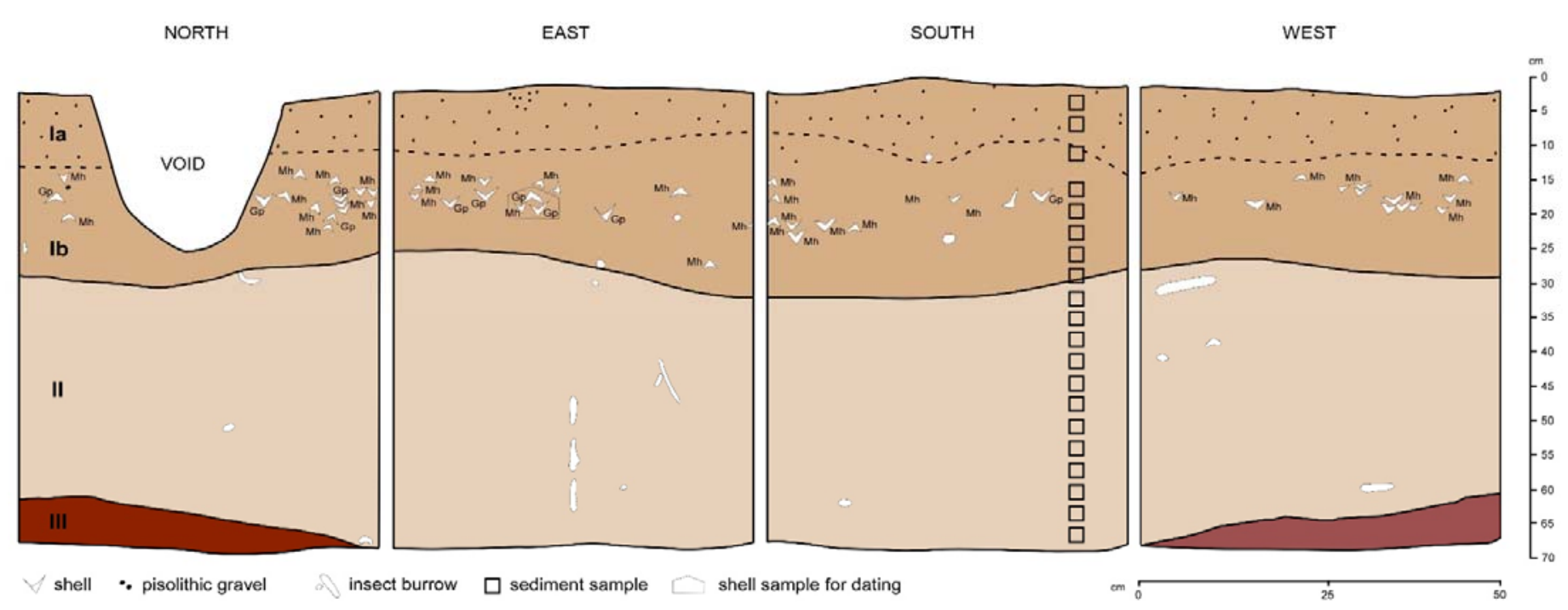

Figure 10. Section drawing of Murdumurdu, Square A divided into three units (I, II, and III) with SUI further divided into subunits Ia and Ib (Section drawing: Michelle Langley and Sean Ulm, 2016). Mh = Marcia hiantina. Gp = Gafrarium pectinatum.

NORTH

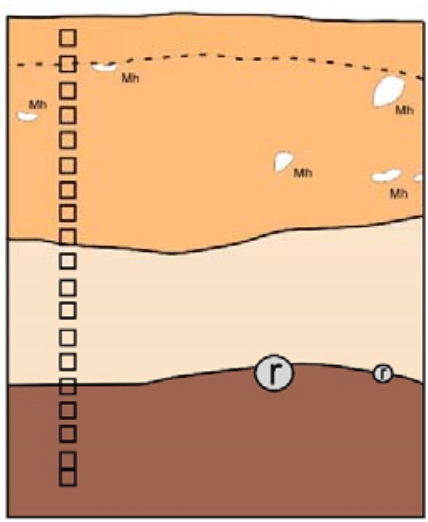

(1) root
EAST

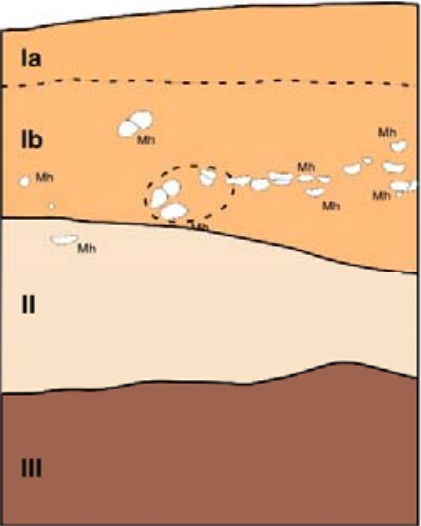

口 sediment sample $\vdots \ldots ;$ shells sample for dating
SOUTH
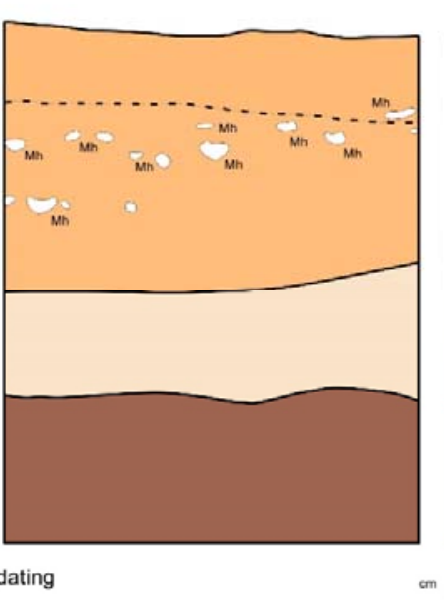

WEST

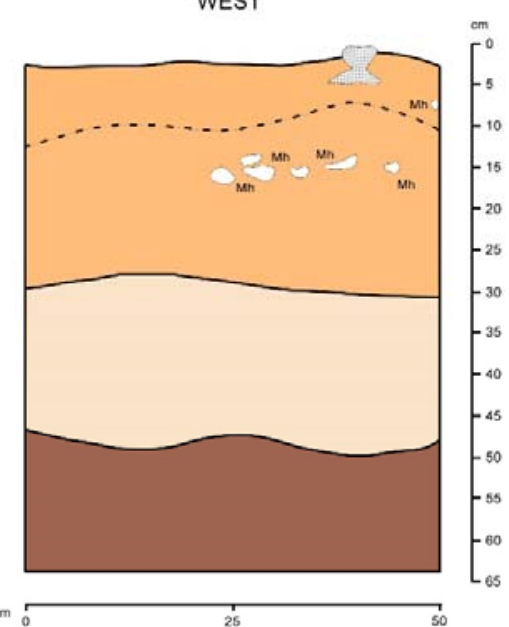

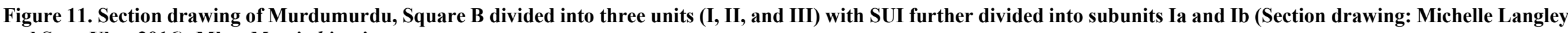
and Sean Ulm, 2016). Mh = Marcia hiantina. 
Table 1. Stratigraphic unit descriptions, Murdumurdu, Squares A and B.

\begin{tabular}{|c|c|}
\hline SU & Desc \\
\hline Ia & $\begin{array}{l}\text { Extends across both squares with depths ranging } 10-15 \mathrm{~cm} \text { below ground surface in Square A and } 5-13 \mathrm{~cm} \text { in Square B. The unit is } \\
\text { comprised of angular to subangular loosely consolidated coarse-grained sand with numerous spinifex grass rootlets. Sediments are } \\
\text { brown }(7.5 \mathrm{YR}-5 / 4) \text { with coarse shell grit interspersed throughout the SU. Small insect burrows are evident, indicating insect } \\
\text { disturbance. Cultural materials include charcoal fragments as well as whole and fragmented M. hiantina and G. pectinatum. } \\
\text { Sediments are highly alkaline }(8.0-10.0 \mathrm{pH}) \text {. Shell material is reasonably well-preserved. }\end{array}$ \\
\hline Ib & $\begin{array}{l}\text { More consolidated coarse-grained brown ( } 7.5 \mathrm{YR}-5 / 4) \text { sand with fewer spinifex grass rootlets and shell grit inclusions. For Square } \\
\text { A SUIb is } 10-25 \mathrm{~cm} \text { below the surface and } 5-30 \mathrm{~cm} \text { below the surface in Square B. Sediment } \mathrm{pH} \text { is alkaline }(7.5-9.0 \mathrm{pH}) \text {. High } \\
\text { concentration of shell between } 15 \mathrm{~cm} \text { and } 25 \mathrm{~cm} \text { comprised of } M \text {. hiantina and G. pectinatum as well as other cultural material (e.g. } \\
\text { fish bone and charcoal). }\end{array}$ \\
\hline II & $\begin{array}{l}\text { Transitional unit grading from brown }(7.5 \mathrm{YR}-5 / 4) \text { to light brown }(7.5 \mathrm{YR}-6 / 4) \text { loosely consolidated coarse-grained sand. Few roots } \\
\text { but numerous and larger insect burrows. Shells found in this unit are likely cultural in origin but are unlikely to be in situ, with } \\
\text { insect bioturbation and other taphonomic factors causing shell fragments to move in the deposit. For Square A SUII is } 25-55 \mathrm{~cm} \\
\text { below the surface and } 30-45 \mathrm{~cm} \text { below the surface in Square B. Sediments are highly alkaline }(8.0-9.5 \mathrm{pH}) \text {. }\end{array}$ \\
\hline III & $\begin{array}{l}\text { Very loosely consolidated coarse-grained sand reddish yellow (7.5YR-6/6) in Square A and pink (7.5YR-7/4) in Square B. SUIII } \\
\text { contains abundant shell grit and small molluscs, including Calliostoma sp. A continuous layer of beach rock forms the base of this } \\
\text { unit at c. } 45-60 \mathrm{~cm} \text { below the surface in Square A. This SU is culturally sterile. Sediments remain highly alkaline }(8.0-9.0 \mathrm{pH}) \text {. }\end{array}$ \\
\hline
\end{tabular}

\section{Radiocarbon Dating and Chronology}

Three AMS radiocarbon age determinations were obtained from the deposits at Murdumurdu, one from Square A and two from Square B (Table 2). Radiocarbon age determinations were undertaken at the University of Waikato Radiocarbon Dating Laboratory. All samples are single valves of marine shell. The sample from Square B, XU4 was obtained from the sieve residue, while the other two samples were collected from the section profiles (see Figures 10-11). The surfaces of all shell samples were cleaned, washed in an ultrasonic bath, acid washed using $0.1 \mathrm{~N} \mathrm{HCl}$, rinsed and dried. Shells were tested for recrystallisation using feigl staining (Friedman 1959), all were determined to be aragonite.

The date from Square A represents the approximate centre of the cultural shell lens, while dates from Square B bracket the top and bottom of cultural deposition. It can therefore be concluded that the major period of deposition at Murdumurdu occurred rapidly c. 300 years ago. Material deposited before or after these dates is likely associated with natural processes, post-depositional movement of materials and/or low-level discard of cultural materials.

\section{Laboratory Methods Identification and Quantification}

Sieve residues were wet-sieved through $2.3 \mathrm{~mm}$ mesh, airdried and sorted under laboratory conditions. Archaeological material from each excavation unit was separated into major categories - shell, bone, stone, crustacean (crab and barnacle), charcoal, organic material - and weighed to the nearest \pm 0.01 g. Organic material comprises roots, leaf litter, seeds, scats and insect remains. Taxonomic identification was undertaken on all marine fauna present in the assemblage following standard zooarchaeological identification procedures (Reitz and Wing 2008). Shell and fish reference collections housed in the James Cook University Tropical Archaeology Research Laboratory (TARL) were used to assist in the identification of archaeological materials (see Tomkins et al. 2013). For a detailed discussion of standard laboratory methods employed see Peck (2016:65-79).

The number of identified specimens (NISP), minimum number of individuals (MNI), and weights $(\mathrm{g})$ were recorded for all identified shell material. Metric analysis (valve height, length and hinge length) of the dominant molluscan taxa ( $M$. hiantina) was undertaken to track size changes through time. Length measurements $(\mathrm{mm})$ are also taken for intact skeletal elements for vertebrate MNI determinations. These measurements are compared to the TARL Fish Reference Collection to estimate body weight of archaeological fish specimens (see Tomkins et al. 2013). Estimates are made using allometric formulas derived from known measurements of reference samples.

\section{Magnetic Susceptibility Analysis}

Magnetic susceptibility is a measure of the ease with which a material can be magnetised in the presence of a magnetic field (Thompson and Oldfield 1986:25). In practice, it detects the magnetic minerals present in soils and sediments, the presence of which can be due to both cultural and natural processes (i.e. fires, pedogenesis or chemical weathering) (Dalan and Banerjee 1998; Ellwood et al. 1997; Herries and Fisher 2010; Linford et al. 2005).

Sediment samples $(n=35)$ were taken from every c. $2.5 \mathrm{~cm}$ down the south profile of Square A and north profile of Square $\mathrm{B}$ and packed in small non-magnetic Althor P-15 boxes (5.28 cc volume). Magnetic susceptibility measurements were completed using a Bartington Instruments MS2B sensor. Repeat measurements were taken for each sample and averaged. Mass and volume low-field magnetic susceptibility ( $\chi$ and $\mathrm{K}$ ) measurements were taken, as well as dual frequencies (460 and $4600 \mathrm{~Hz}$ ) for the frequency dependence of susceptibility $(\chi \mathrm{fd})$. Frequency dependence is the difference between the measured magnetic susceptibilities at low and high frequency, and is expressed either as a relative loss of susceptibility $(\chi \mathrm{fd}=\chi 460 \mathrm{~Hz}-\chi 4600 \mathrm{~Hz})$, or a percentage loss of the low frequency value $(\chi \mathrm{fd} \%=\chi 460 \mathrm{~Hz}-$ $\left.\chi 4600 \mathrm{~Hz} / \chi^{460 H z}{ }^{*} 100\right)$ (Dearing et al. 1996; Maher 1986). Measurement of $\chi \mathrm{fd} \%$ shows the contribution of ultrafine or superparamagnetic (SP) grains $(>0.03 \mu \mathrm{m})$ (Dearing et al. 1996). Increases in $\chi \mathrm{fd} \%$ with increases in magnetic susceptibility indicate an increase in the percentage of SP grains which is indicative of burned or well-developed soils (Dalan and Banerjee 1998; Dearing et al. 1996). 
Table 2. AMS radiocarbon determinations on marine shell from Murdumurdu, Squares A and B. Radiocarbon ages were calibrated using OxCal 4.3 (Bronk Ramsey 2009) and the Marine13 calibration dataset (Reimer et al. 2013), with a $\Delta R$ of $-49 \pm 102$ (Ulm et al. in prep.). All calibrated age are reported at the $95.4 \%$ age range. * $=$ date may extend out of range (i.e. modern).

\begin{tabular}{|c|c|c|l|l|c|c|c|c|c|}
\hline Square & XU & $\begin{array}{c}\text { Depth } \\
(\mathbf{c m})\end{array}$ & \multicolumn{1}{|c|}{ Sample } & Lab. No. & $\begin{array}{c}\boldsymbol{\delta}^{\mathbf{1 3}} \mathbf{C} \\
\mathbf{( \% )}\end{array}$ & $\mathbf{\%}$ Modern & $\begin{array}{c}\mathbf{1 4}_{\mathbf{C}} \text { Age } \\
\text { (years BP) }\end{array}$ & $\begin{array}{c}\text { Calibrated } \\
\text { Age BP } \\
\mathbf{( 9 5 . 4 \% )}\end{array}$ & $\begin{array}{c}\text { Median } \\
\text { Calibrated } \\
\text { Age BP }\end{array}$ \\
\hline A & $5-6$ & $14-17$ & Gafrarium pectinatum & Wk-34780 & $1.7 \pm 0.2$ & $92.3 \pm 0.3$ & $640 \pm 25$ & $76-508$ & 328 \\
\hline B & 4 & 12 & Marcia hiantina & Wk-44446 & NA & $92.7 \pm 0.2$ & $606 \pm 20$ & $0 *-484$ & 293 \\
\hline B & $7-8$ & $20-24$ & Marcia hiantina & Wk-34776 & $0.9 \pm 0.2$ & $92.4 \pm 0.3$ & $634 \pm 27$ & $68-504$ & 322 \\
\hline
\end{tabular}

\section{Stable Isotopic Analysis}

Archaeological M. hiantina specimens $(n=30)$ were sampled throughout the cultural deposit of both squares for seasonality determination using stable isotopic analysis $\left(\delta^{18} \mathrm{O}\right.$ and $\left.\delta^{13} \mathrm{C}\right)$. All isotopic analyses were conducted at the Advanced Analytical Centre, James Cook University, Cairns. The efficacy of this species as a seasonality proxy is outlined in Twaddle (2016). To ensure sample assemblages provided a representation of species abundance, a percentage-based sampling approach was implemented. A sample of 5\% (rounded to the nearest 10) of the total M. hiantina MNI was sampled from each XU. If the number of suitable individuals totalled less than $5 \%$ of the XUs MNI, all usable specimens were selected. Suitability of valves for analysis was determined using the criteria in Table 3.

Table 3. Selection criteria applied to specimens targeted for isotopic analysis.

\begin{tabular}{|l|}
\hline \multicolumn{1}{|c|}{ Specimen Selection Criteria } \\
\hline $\begin{array}{l}\text { Identified either as one of a refitted valve-pair OR no conjoining } \\
\text { valve was found. }\end{array}$ \\
\hline Largely intact ventral margin - minimal macroscopic damage. \\
\hline Minimal wear on outer shell surface. \\
\hline $\begin{array}{l}\text { No evidence of burning or exposure to fire - burnt sections or } \\
\text { association with hearth features. }\end{array}$ \\
\hline Upper shell layer intact and preserved. \\
\hline $\begin{array}{l}\text { Preferably whole valve, however fragments are also suitable } \\
\text { provided they are of sufficient size to generate adequate } \\
\text { carbonate sample from the ventral margin and have landmarks } \\
\text { allowing minimum number of individuals (MNI) determination } \\
\text { to identify specimens as individuals. }\end{array}$ \\
\hline
\end{tabular}

After all adhering particulates had been removed from sampled valves via manual abrasion and an ultrasonic bath of deionised water, a carbonate powder sample $(40-80 \mu \mathrm{g})$ from the edge margin of each specimen was removed using a Dremel 3000 Rotary Tool fitted with a cylindrical diamond wheel (Dremel $2.4 \mathrm{~mm} 7122$ Point Diamond Wheel). A secondary, larger carbonate sample (c. $2 \mathrm{mg}$ ) was taken near the umbo to test for recrystallisation. Umbo powder samples were analysed using a Bruker Alpha-T Fourier Transform Infrared Spectroscopy unit against known aragonite and calcite standards. Edge margin samples were placed in exetainer vials, flush filled with helium, and acidified with $100 \%$ phosphoric acid before being left to equilibrate for 18 hours at $25^{\circ} \mathrm{C}$. Analysis of stable oxygen and carbon isotope composition was undertaken using a Thermo GasBench III connected to a DeltaVPLUS (ThermoFisher) gas source mass spectrometer via a ThermoFisher ConFloIV. Each run of samples was accompanied by at least five standards (NBS-18) and three control samples (NBS-19) with similar mass to unknown samples. The results are reported with reference to the international standard Vienna Pee Dee Belmnite (VPDB) with precision better than $0.1 \%$ for both $\delta^{18} \mathrm{O}$ and $\delta^{13} \mathrm{C}$.

\section{Cultural Materials}

Of the total sediment and material excavated, 3566.29g (1.5\%) from Square A and 2445.19g (1\%) from Square B were retained in the $2.3 \mathrm{~mm}$ sieve indicating a very lowdensity cultural deposit (Figure 12). See Appendices A and B for overall summary results of the retained materials. Molluscan shell makes up 90.5\% (3228.46g) of the Square A assemblage and $83.9 \%(2050.27 \mathrm{~g})$ of the Square B assemblage. Fish bone contributes $0.04 \%(1.45 \mathrm{~g})$ for Square $\mathrm{A}$ and $0.02 \%(0.45 \mathrm{~g})$ for Square B. Small quantities of crustacea $(16.8 \mathrm{~g})$ were recovered from both squares combined, consisting of mud crab (Scylla spp.) (2.4g) and goose barnacle (Pedunculata) (14.4g). Beachrock, coral, and pisoliths (classed as non-artefactual stone) contribute $6.2 \%$ of Square A and $5.5 \%$ of Square B. The remainder of the assemblage consists of organics. No stone artefacts were recovered from either square.

\section{Marine Invertebrates Square A}

A total of $3228.46 \mathrm{~g}$ of shell was recovered from Square A. Of this, $75 \%$ of shell material (by weight) was identified to family, genus, or species level. The remaining $25 \%$ could not be identified beyond Mollusca owing to generally small specimen size and a lack of diagnostic attributes. The proportion of unidentified material increases with depth from an average of $37.9 \%$ for XUs $1-10$ to $93.2 \%$ for XUs $11-20$ reflecting increased fragmentation and weathering with depth and age. This portion of the assemblage has not been included in the analyses presented below, but was quantified (Appendix D). The identified assemblage comprised 27 molluscan taxa (total weight $=2430.67 \mathrm{~g} ; \mathrm{MNI}=591$ ) consisting of 17 marine bivalve taxa and 10 marine gastropod taxa (Figures 13-14). By weight, the assemblage is dominated by tumid venus clams (G. pectinatum) $(54.4 \%)$, hiant venus clams (M. hiantina) $(41.9 \%)$, and tiar venus clams (Placamen retroversum) (1.1\%). The remaining 24 taxa are relatively rare, each contributing less than $1 \%$ of the shell assemblage by weight. MNI and weight tables are presented in Appendices C and D. 

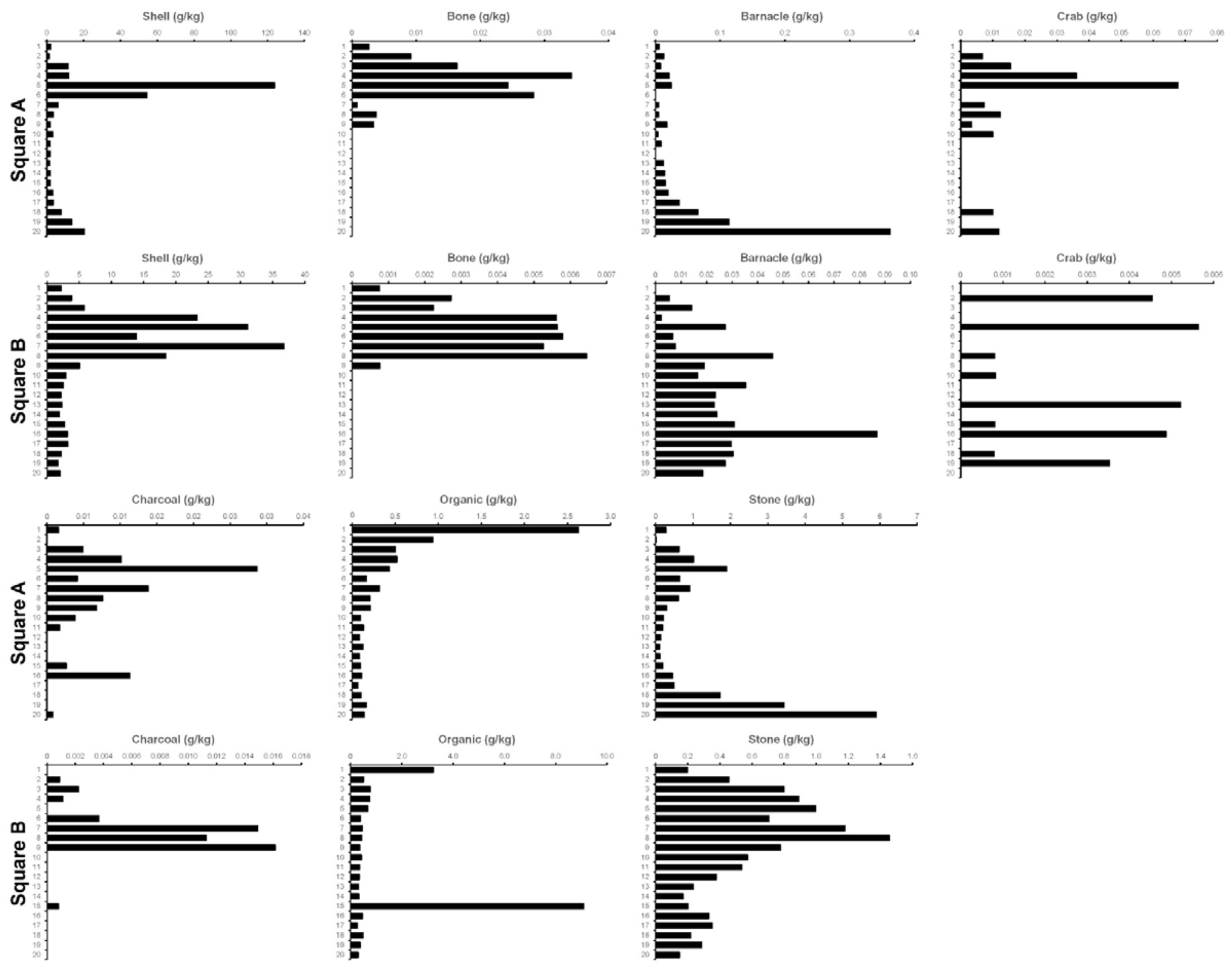

Figure 12. Murdumurdu, Squares A and B, distribution of cultural materials by $\mathrm{g} / \mathrm{kg}$ by XU. 


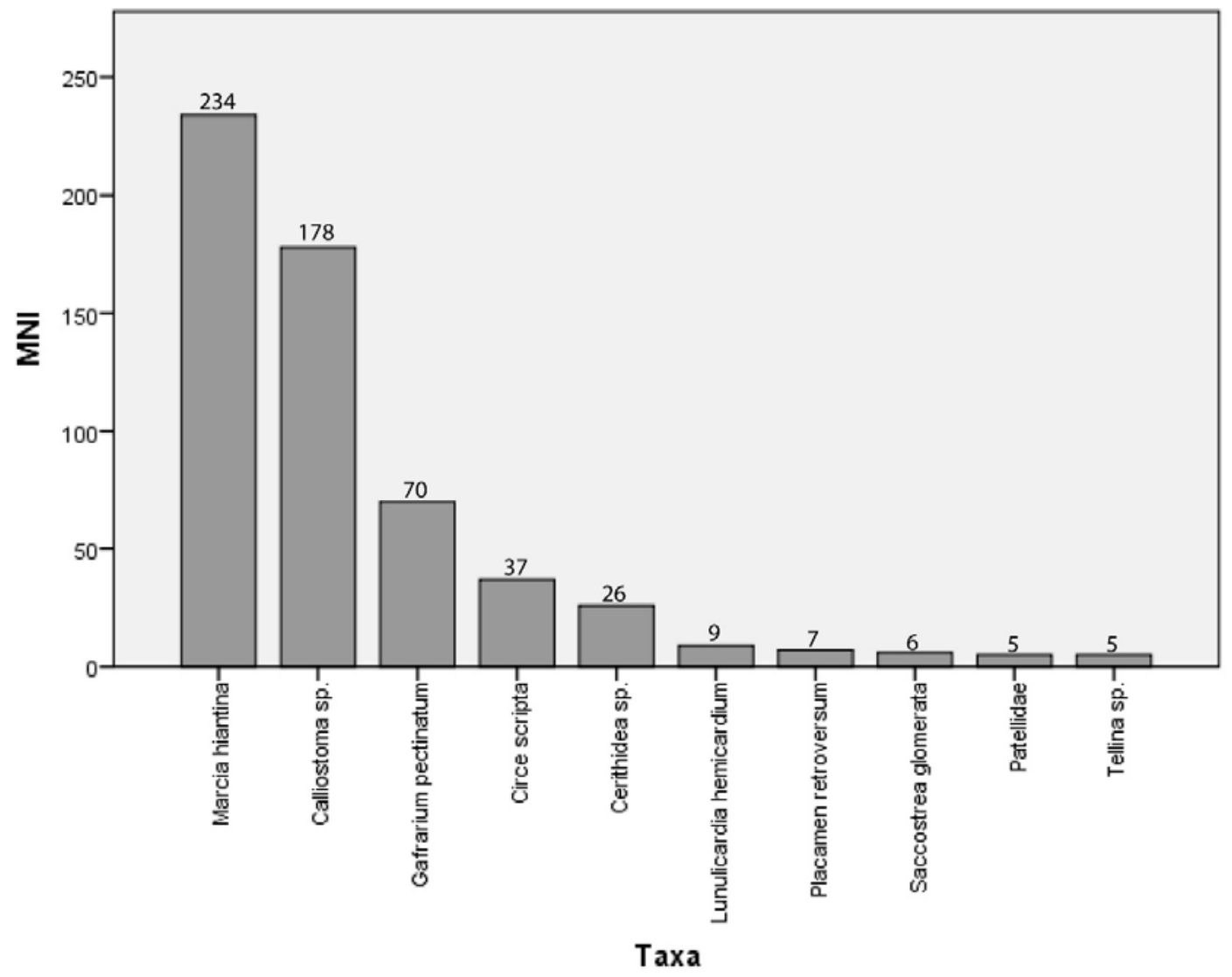

Figure 13. Murdumurdu, Square A, top 10 molluse taxa by MNI.

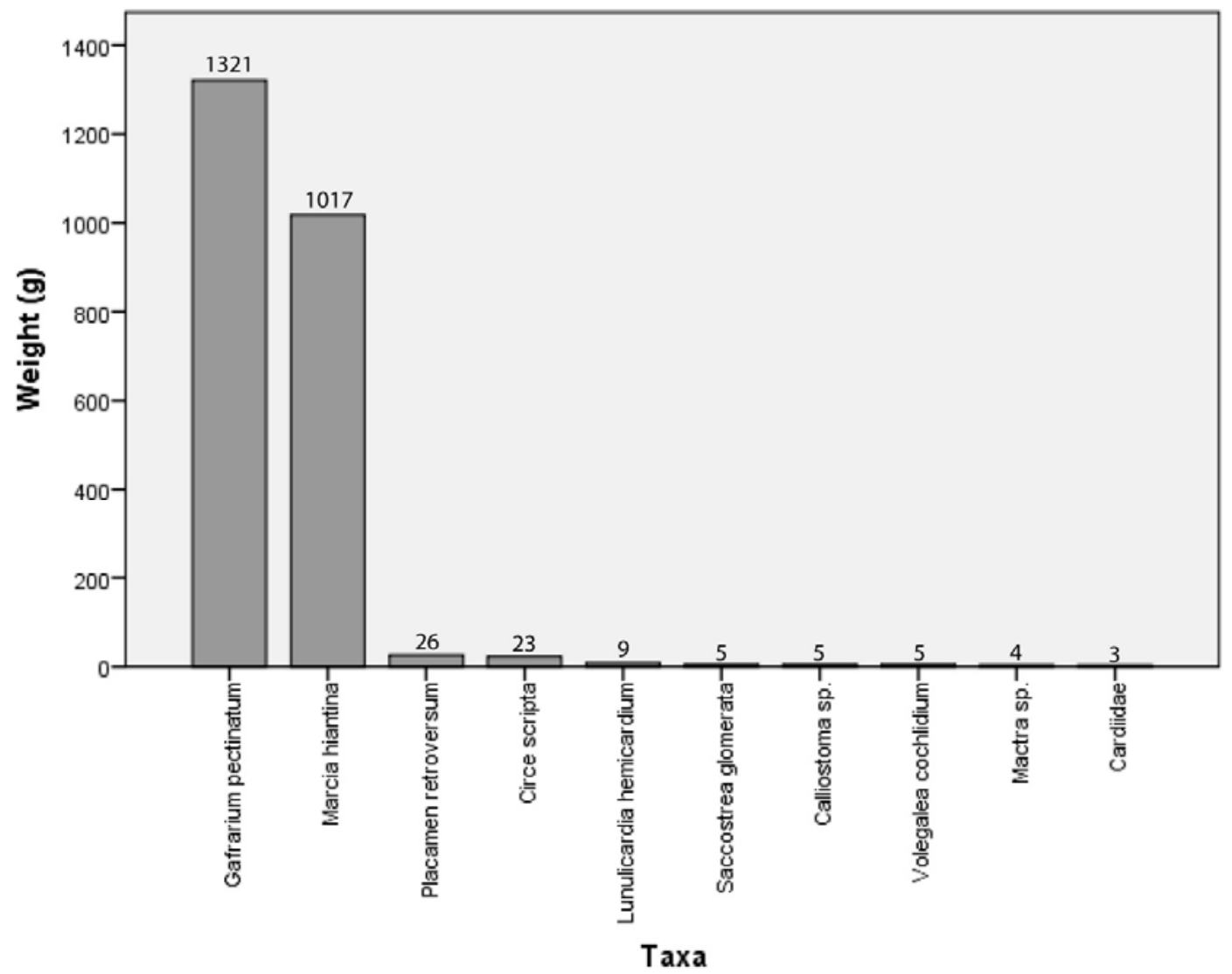

Figure 14. Murdumurdu, Square A, top 10 mollusc taxa by weight. 
The shell deposit in Square A is concentrated between XU3 and 7 (dated to c. 300 cal BP), accounting for $61 \%$ of identified mollusc assemblage based on MNI, suggesting a significant period of use at the site around this time. Although XUs 19 and 20 contain elevated MNI numbers, this can largely be attributed to small gastropods that are not considered cultural in nature. The assemblage exhibits moderate diversity with a calculated Shannon-Weaver Index of 2.74 , while $91 \%$ of the assemblage comprises five species. The high presence of venus clams, top shells, Pacific cockles, and cerithid snails suggest that foraging strategies encompassed three habitats, intertidal sand-mud flats, rocky reefs, and mangroves and tidal-mud flats.

\section{Square B}

A total of $2050.27 \mathrm{~g}$ of shell was recovered from Square B. Of this, $74 \%$ of all shell (by weight) was identified to family, genus, or species level. The remaining $26 \%$ could not be identified beyond Mollusca owing to the generally small size of specimens and lack of diagnostic attributes. The proportion of unidentified material increases with depth from an average of $29.1 \%$ for XUs $1-10$ to $92.4 \%$ for XUs $11-20$ reflecting increased fragmentation and weathering. This portion of the assemblage is not considered in analyses presented below, but was quantified (see Appendix F). The identified assemblage comprised 20 taxa (total weight $=1515.91 \mathrm{~g} ; \mathrm{MNI}=466$ ) consisting of 14 marine bivalve taxa and 6 marine gastropod taxa (Figures 15-16). The assemblage is dominated by hiant venus clams ( $M$. hiantina), representing $98.9 \%$ of shell material by weight. The remaining 19 taxa are relatively rare, each contributing less than $1 \%$ of the shell assemblage by weight. MNI and weight tables are presented in Appendices E and $\mathrm{F}$.

The shell deposit in Square B is concentrated between XU3 and XU9 (dated to c. 300 cal BP) accounting for $65 \%$ of the identified mollusc assemblage based on MNI, suggesting a period of significant use broadly contemporaneous with that observed in Square A. The assemblage exhibits moderate diversity with a calculated Shannon-Weaver Index of 2.85 , while $90 \%$ of the assemblage comprises three species. The high presence of hiant venus clams suggests that foraging strategies focused on intertidal sand-mud flats.

When reviewing the relationship between the hiant venus clam MNI and specimen sizes for each period, there is a decrease in hiant venus clam MNI quantities through time matched by an increase in mean valve length (Table 4 ). This may suggest a relationship exists between these variables, however without further definitive dates it is difficult to know if this reflects foraging efficiency in the adjacent sandy-mud flats, forager's cultural choice or lower occupation intensity in more recent times.

\section{Magnetic Susceptibility Analysis}

Magnetic susceptibility analysis reveals a strong correlation between the stratigraphic units in the sedimentary sequence. The samples are weakly magnetic in the basal unit of SUIII and SUII (Figure 17). On average, the $\chi \mathrm{fd} \%$ measurements in these units are about $5 \%$. Susceptibility values begin to increase in the upper portion of SUIb in both squares, with increases in shell, bone and charcoal. Susceptibility values are highest at around $20 \mathrm{~cm}$ in both squares, with slightly weaker peaks around $25-30 \mathrm{~cm}$.
The $\chi \mathrm{fd} \%$ for all samples ranges between $3 \%$ and $8 \%$, indicating a mix of magnetic grain sizes. Increases in both magnetic susceptibility and $\chi \mathrm{fd} \%$ occur only in Square B, around 15-20cm in SUIb (cf. Dearing et al. 1996). Increases in both magnetic susceptibility and $\chi \mathrm{fd} \%$ are likely related to human interaction with the sediment, in the form of anthropogenic burning, indicating a change in the finegrained component of magnetic grains at these depths. Shell, bone and charcoal increase at this depth supporting this interpretation. There is no evidence of developed soil horizons at this depth. The inverse change of higher $\chi \mathrm{fd}$ percentages and low magnetic susceptibility values in SUII are likely derivatives of sediment changes (increases in sands and less artefactual material). This also applies to the lower part of SUIII or in the culturally sterile basal layers, which contains no shells and the presence of small beach rocks.

A bivariate plot (Figures 18-19) of $\chi$ to $\chi \mathrm{fd} \%$ provides information on the relationships between the two parameters and the proportion of fine SP grains. For both Square A and Square B, the upper deposits of SUIa and SUIb are all concentrated in one area (right side) of the plot, while the lower deposits of SUII and SUIII are concentrated on the left side of the plot. This means there are differences in the concentration of magnetic minerals within the deposits. On average, the upper deposits contain lower $\chi \mathrm{fd} \%$, and this could reflect younger soils (see Rosendahl et al. 2014b).

\section{Stable Isotopic Analysis Square A}

M. hiantina specimens tested for recrystallisation returned wavelength plots indicative of aragonite, indicating no recrystallisation. $\delta^{18} \mathrm{O}_{\text {shell }}$ values returned a range of $-3.7 \%$ to $-0.2 \%$ (mean $=-1.5 \%$; $1 \sigma= \pm 0.9 \%$ ). The majority of these values $(87 \% ; n=13)$ are grouped within $1 \sigma$ of the overall mean, with $94 \%(n=14)$ within $2 \sigma$. These closely grouped, relatively positive values suggest that $M$. hiantina were gathered during cool marine conditions throughout the occupation of Murdumurdu (Figure 20). Comparisons with seasonal $\delta^{18} \mathrm{O}_{\text {shell-predicted }}$ ranges indicate close links between expected dry season values and analysed archaeological edge margins. No specimens fall outside the dry season, although the value from XU8 was on the lower border of the dry season range. Similar consistent results were evidenced in $\delta^{13} \mathrm{C}_{\text {shell }}$ values, which range between $-2.7 \%$ and $+0.9 \%$ (mean $=-$ $1.3 \%$; $1 \sigma= \pm 0.9 \%$ ). However, data are less tightly grouped than oxygen with $67 \%(n=10)$ within $1 \sigma$ and $94 \%(n=14)$ within $2 \sigma$. Relatively positive $\delta^{13} C_{\text {shell }}$ values suggest little interaction with terrestrial carbon sources, with carbonates being built primarily from marine reservoirs (see Petchey et al. 2013).

\section{Square B}

Mollusc specimens tested for recrystallisation returned wavelength plots indicative of aragonite, indicating no instances of pre- or post-depositional recrystallisation. $\delta^{18} \mathrm{O}_{\text {shell }}$ values from Square B are similar to those from Square $\mathrm{A}$, with a range of $-2.8 \%$ o to $+0.4 \%$ o (mean $=-0.8 \%$; $1 \sigma=$ $\pm 1.0 \%$ ). Values are not as tightly clustered, spread equally across $1 \sigma(n=7 ; 54 \%)$ and $2 \sigma(n=6 ; 46 \%)$ ranges. Despite this, data grouping and consistently positive values suggest that M. hiantina from Square B were collected during cool marine conditions. Applying seasonal $\delta^{18} \mathrm{O}_{\text {shell-predicted }}$ ranges confirms this, with all values remaining within the dry season 


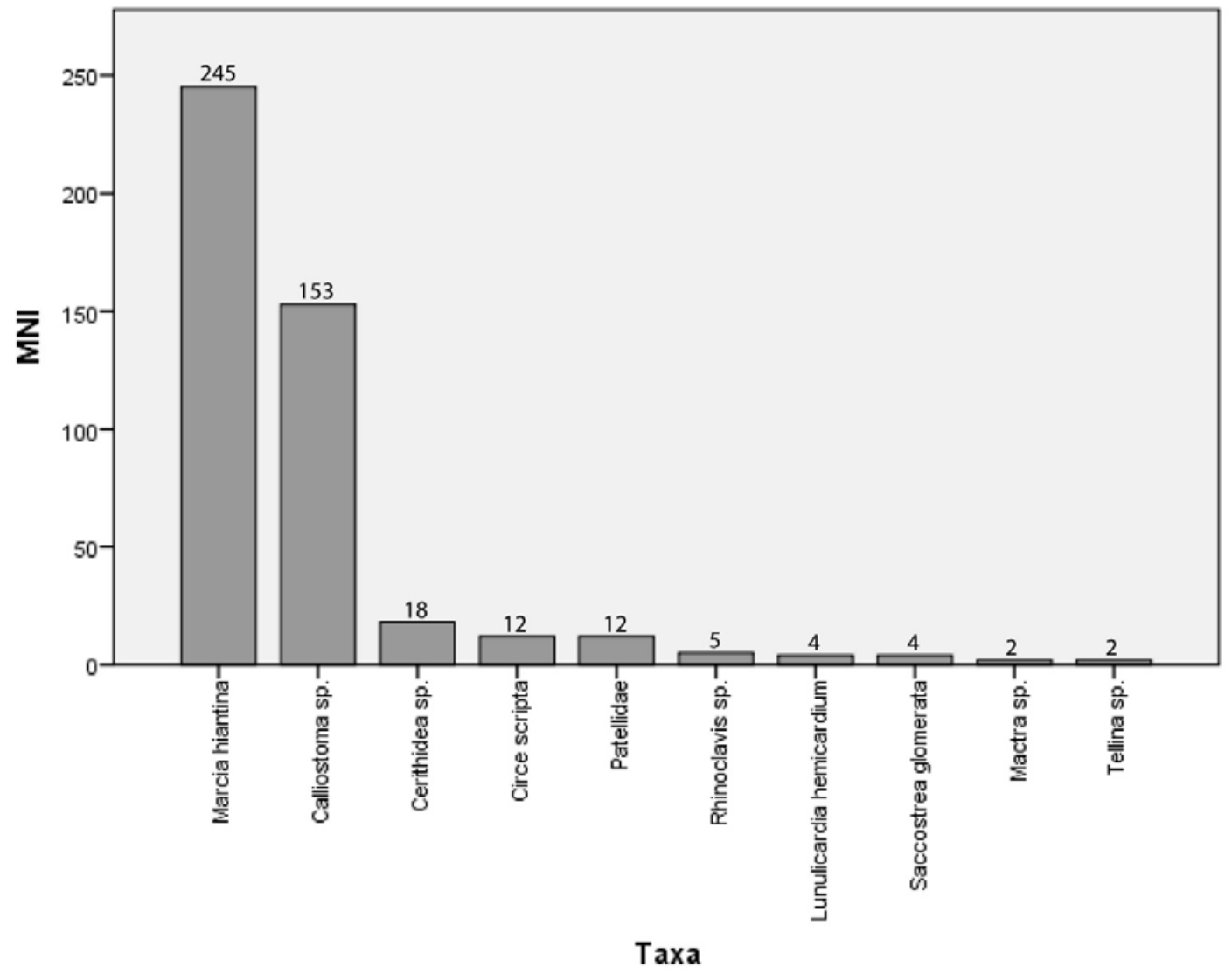

Figure 15. Murdumurdu, Square B, top 10 mollusc taxa by MNI.

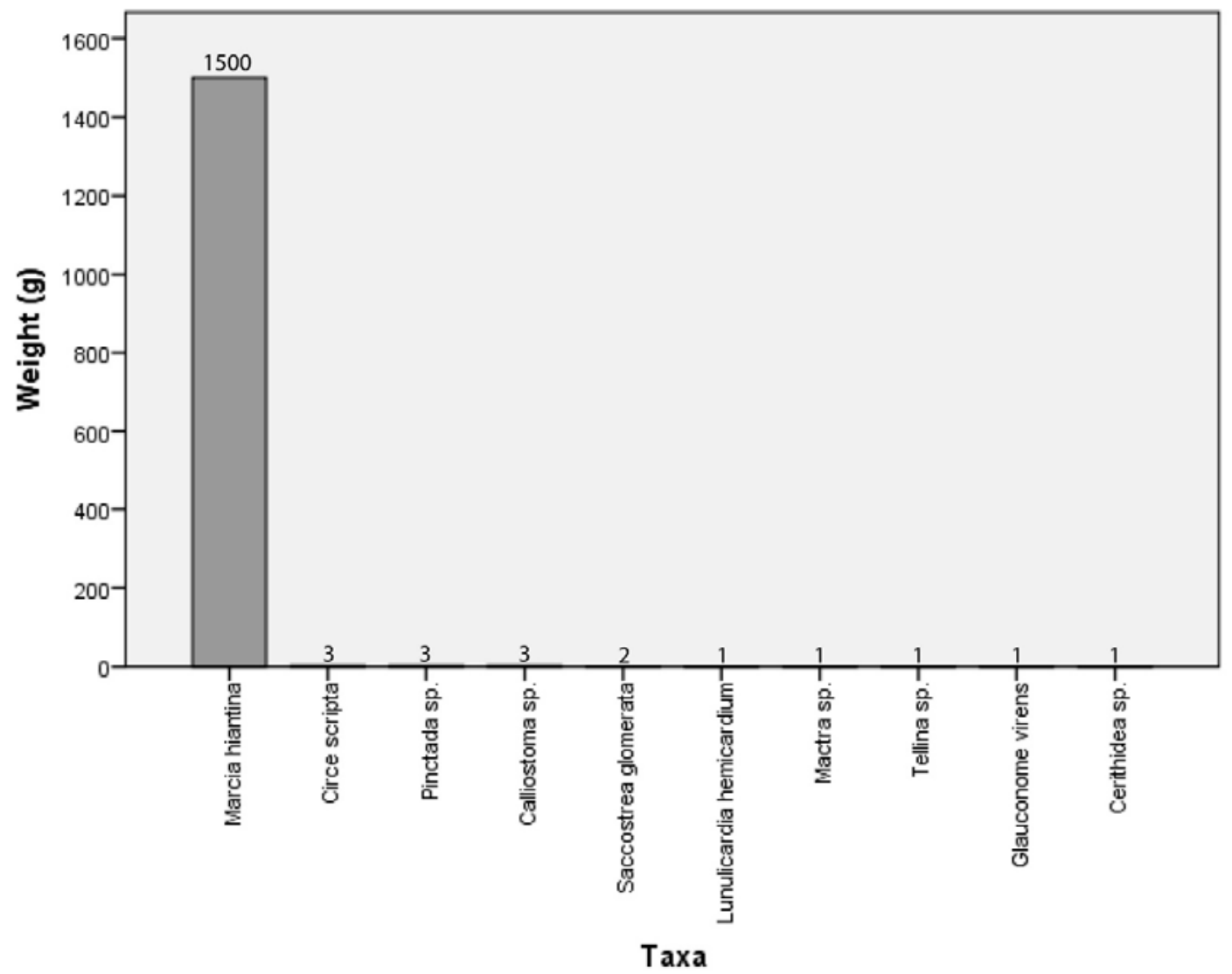

Figure 16. Murdumurdu, Square B, top 10 mollusc taxa by weight. 
Table 4. Metrical length data for M. hiantina valves from Murdumurdu, Squares A and B combined. Note that XUs in Squares $A$ and $B$ are of a comparable depth (see Appendix A and B).

\begin{tabular}{|r|r|r|r|r|r|r|r|}
\hline $\mathbf{X U}$ & \multicolumn{1}{|c|}{$\begin{array}{c}\text { Mean } \\
(\mathbf{m m})\end{array}$} & $\begin{array}{c}\text { Median } \\
(\mathbf{m m})\end{array}$ & \multicolumn{1}{c|}{$\begin{array}{c}\text { S.D. } \\
(\mathbf{m m})\end{array}$} & \multicolumn{1}{c|}{$\begin{array}{c}\text { Min. } \\
(\mathbf{m m})\end{array}$} & \multicolumn{1}{c|}{$\begin{array}{c}\text { Max. } \\
(\mathbf{m m})\end{array}$} & \multicolumn{1}{c|}{$\begin{array}{c}\text { Range } \\
(\mathbf{m m})\end{array}$} & No. \\
\hline 2 & 34.82 & 34.35 & 2.98 & 30.48 & 38.32 & 7.84 & 6 \\
\hline 3 & 34.88 & 35.24 & 1.34 & 33.03 & 36.36 & 3.33 & 7 \\
\hline 4 & 33.42 & 33.72 & 2.44 & 24.73 & 38.47 & 13.74 & 66 \\
\hline 5 & 32.82 & 32.90 & 2.23 & 27.42 & 38.21 & 10.79 & 87 \\
\hline 6 & 33.49 & 33.10 & 2.31 & 29.27 & 39.32 & 10.05 & 51 \\
\hline 7 & 34.58 & 34.56 & 3.02 & 24.97 & 40.08 & 15.11 & 42 \\
\hline 8 & 35.09 & 35.13 & 3.06 & 30.32 & 41.72 & 11.40 & 9 \\
\hline 9 & 31.90 & 31.90 & 0.00 & 31.90 & 31.90 & 0.00 & 1 \\
\hline
\end{tabular}

Square A
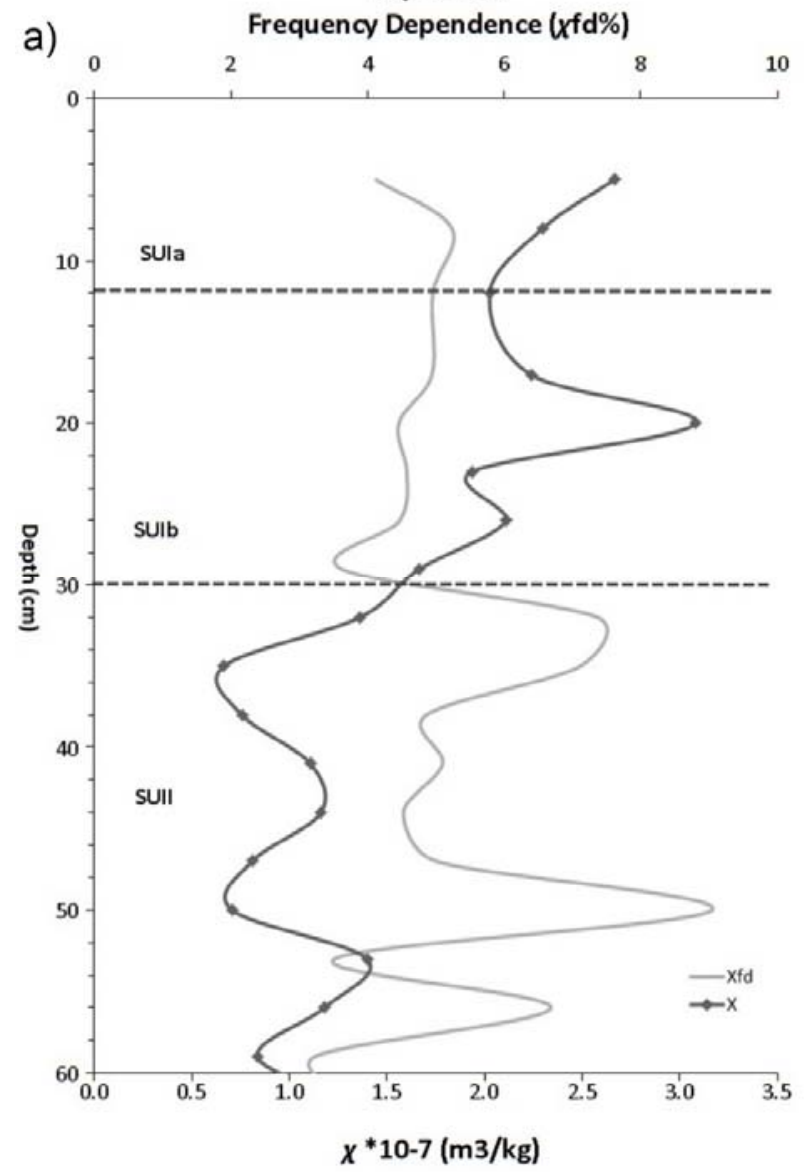

Square B

b) Frequency Dependence (xfd\%)

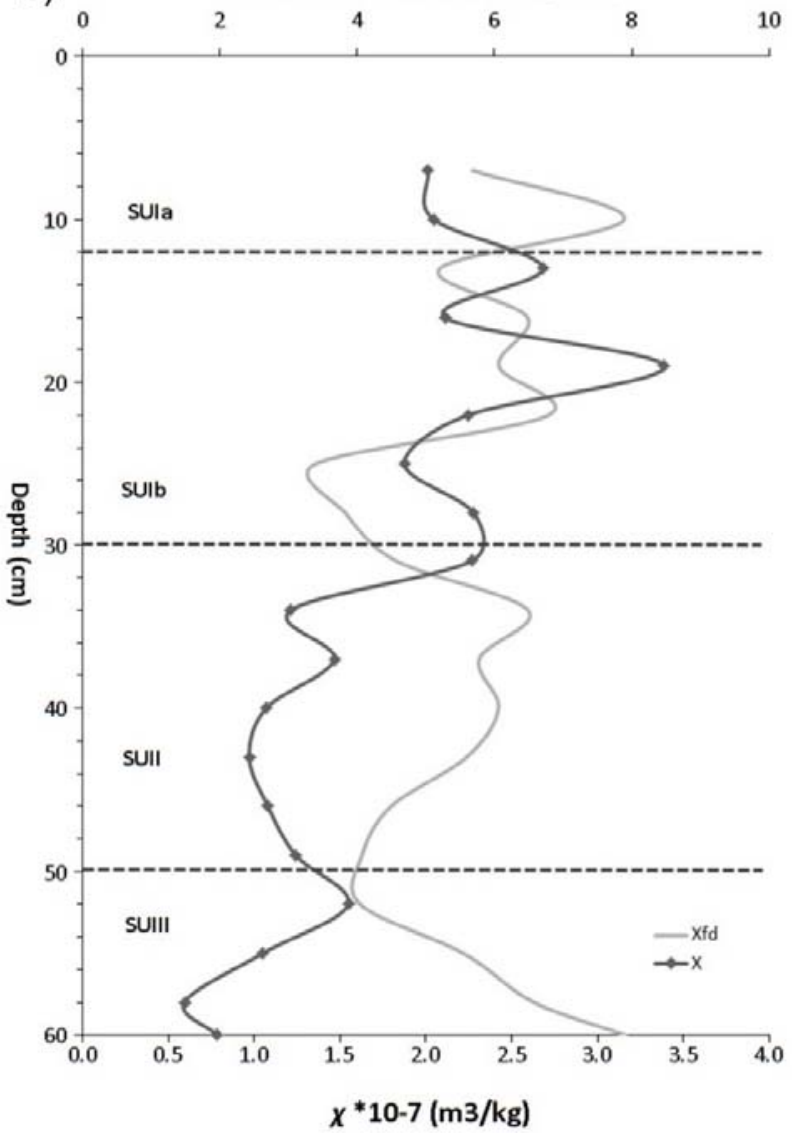

Figure 17. Profile of low-field magnetic susceptibility $(\chi)$ and frequency dependence of susceptibility $(\chi \mathbf{f d} \%)$ of Square A (a) and Square B (b). See Appendices $I$ and $J$ for raw data. 


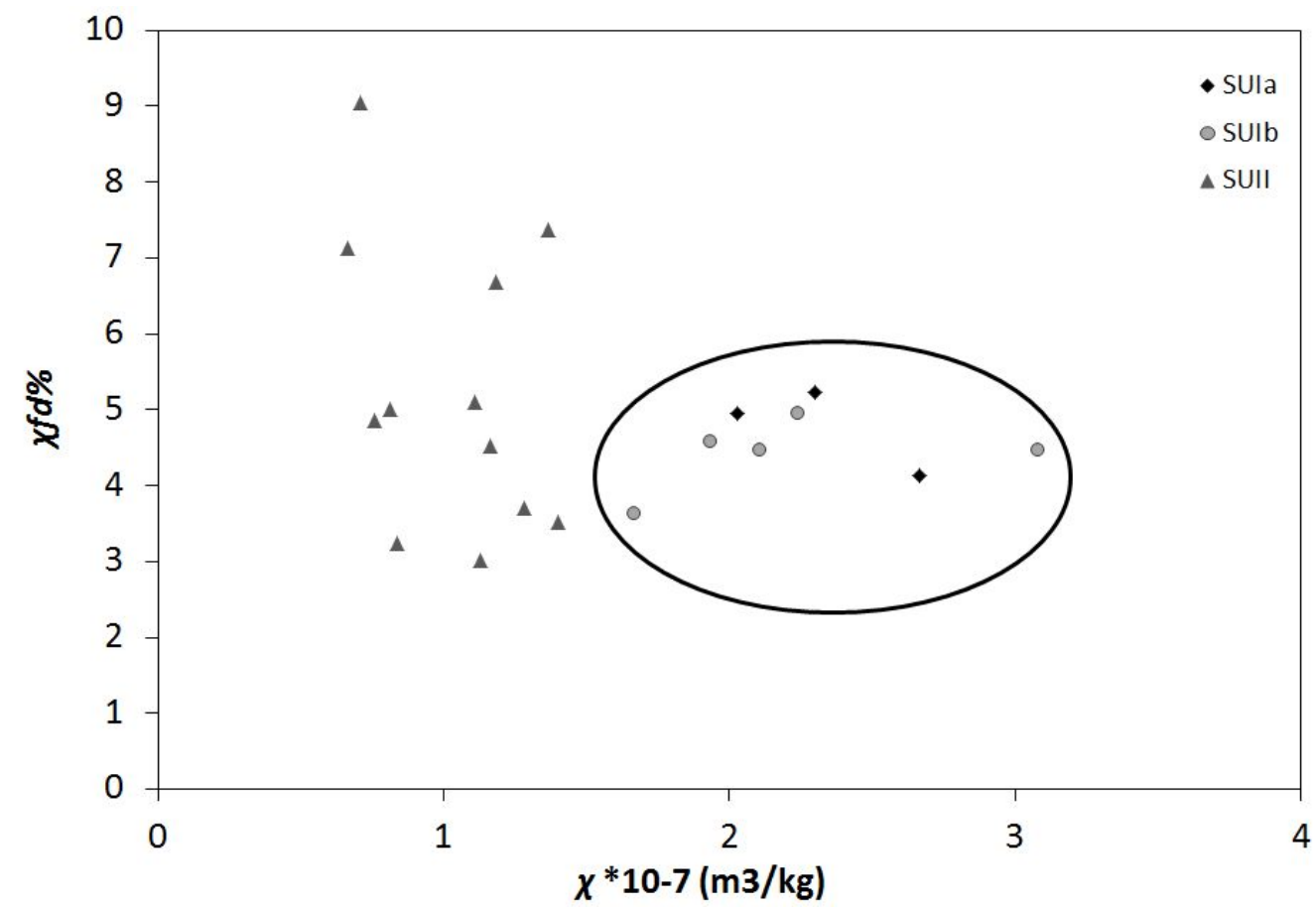

Figure 18. Bivariate plot showing the relationship between $\chi$ with $\chi \mathrm{fd} \%$ for Murdumurdu, Square A.

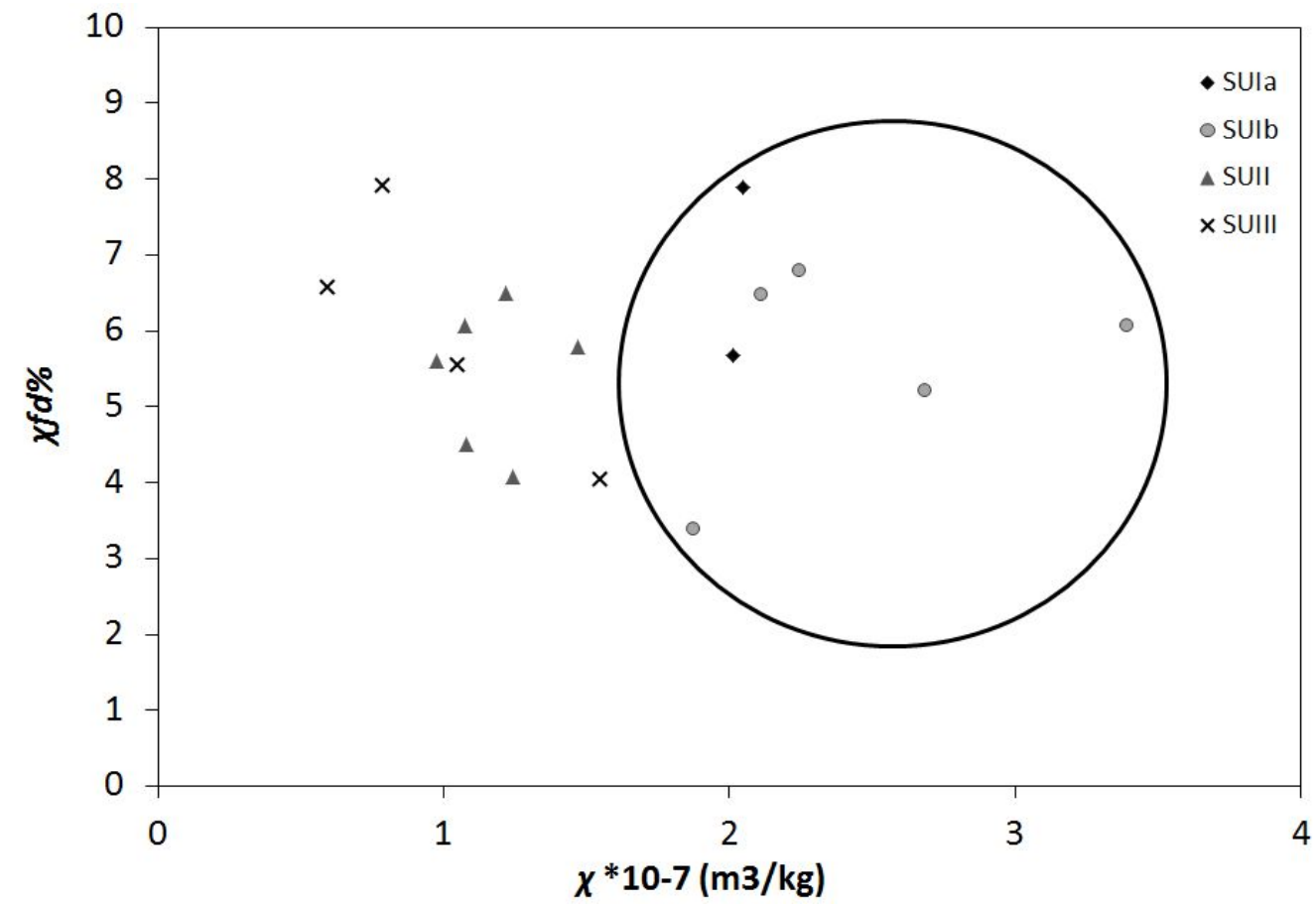

Figure 19. Bivariate plot showing the relationship between $\chi$ with $\chi \mathrm{fd} \%$ for Murdumurdu, Square B. 


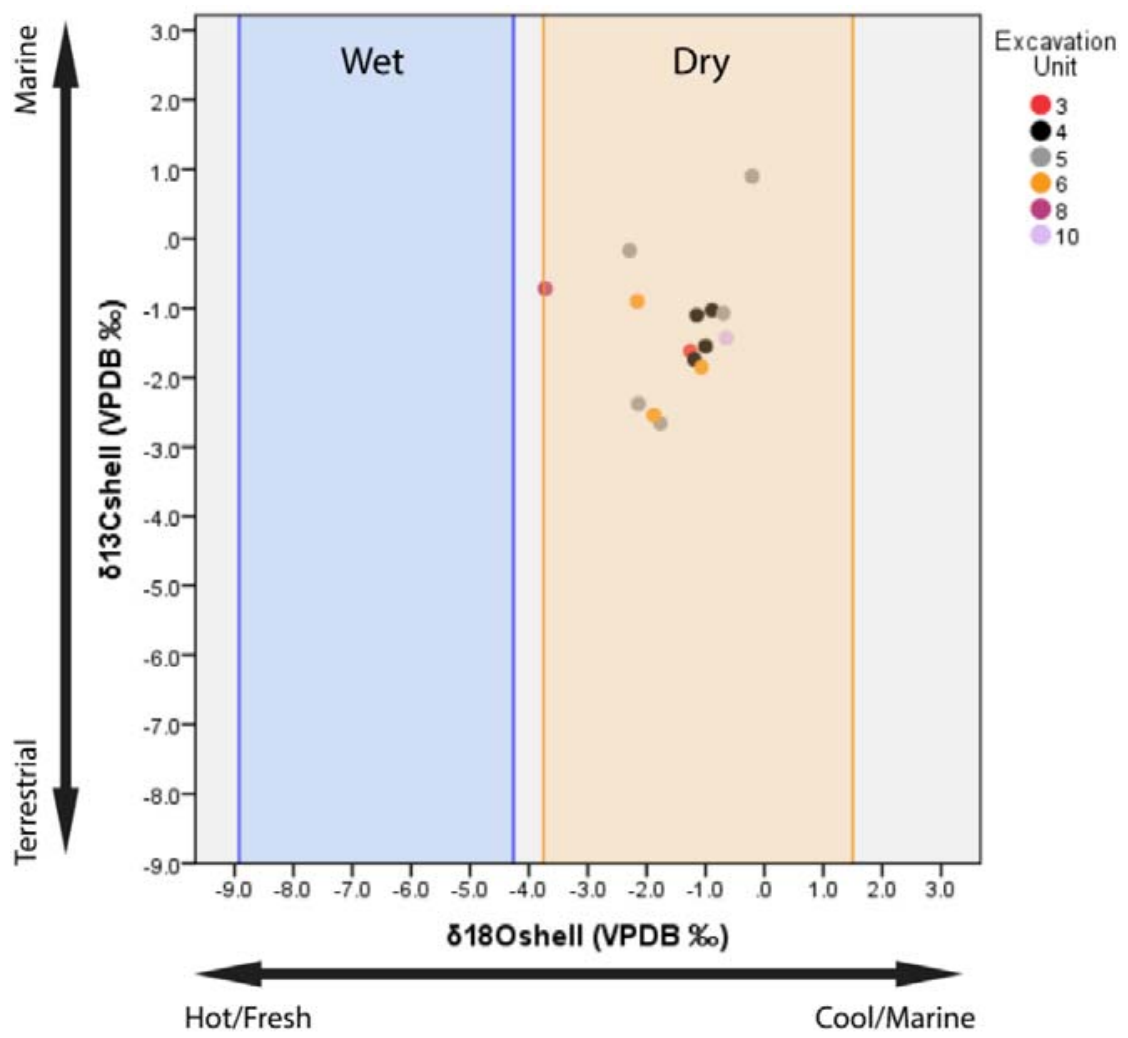

Figure 20. Stable isotope values from archaeological M. hiantina at Murdumurdu, Square A are indicative of collection during cool marine conditions, with all values falling within the predicted dry season range (orange shaded area). See Appendix K for raw data.
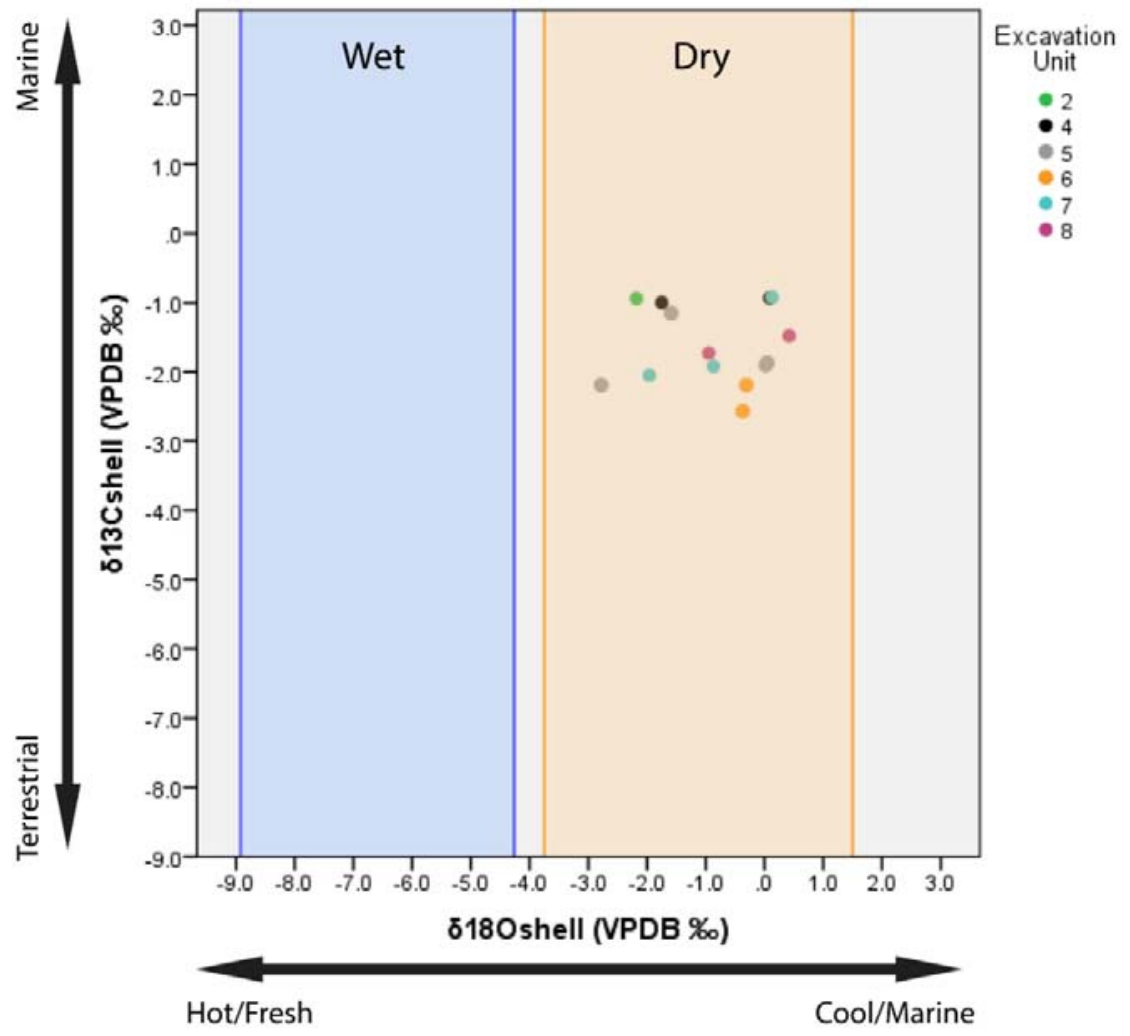

Figure 21. Stable isotope values from archaeological $M$. hiantina at Murdumurdu, Square B are indicative of collection during cool marine conditions, with all values falling within the predicted dry season range (orange shaded area). See Appendix $\mathrm{K}$ for raw data. 
range (Figure 21). Stable conditions are also evidenced in $\delta^{13} C_{\text {shell }}$ values, which are grouped between $-2.6 \%$ and $-0.9 \%$ o (mean $=-1.6 \% ; 1 \sigma= \pm 0.6 \%$ ). These values are evenly scattered throughout the entire range with $38 \%(n=5)$ within $1 \sigma$ and $62 \%(n=8)$ within $2 \sigma$, while the remaining $38 \%(n=$ 5 ) are outside $2 \sigma$. Despite this spread, $\delta^{13} C_{\text {shell }}$ values are relatively positive suggesting that carbonates were primarily constructed from marine DIC (see Petchey et al. 2013).

\section{Vertebrate Remains}

\section{Square A}

Small quantities of fish bones $(n=58)$ were recovered from the upper nine XUs of Square A, comprising the only vertebrate remains $(1.44 \mathrm{~g}$ ) in this square (see Appendix $\mathrm{G}$ for full details of fish bone assemblage). Most of the bone material was highly fragmented and little could be identified to taxon beyond Osteichthyes (bony fishes). An MNI of two was calculated by summing the MNI for each excavation unit. Identified taxa include grass emperor (Lethrinus laticaudis) and wrasse (Labridae). Based on comparison with a grass emperor otolith in the TARL Fish Reference Collection measuring $9.5 \mathrm{~mm}$ and weighing $400 \mathrm{~g}$, the otolith specimen from XU5 (measuring $11 \mathrm{~mm}$ ) is estimated to originate from a fish weighing c.450g. Similarly, the wrasse specimen from XU4 (measuring 9.0mm) is estimated to come from a fish weighing c.350g.

\section{Square B}

As with Square A, only small quantities $(n=28)$ of fish bone were recovered from the upper nine XUs of Square B, comprising the only vertebrate remains $(0.45 \mathrm{~g})$ in this square (see Appendix $\mathrm{H}$ for full details of fish bone assemblage). The majority of the bone material was highly fragmented and little could be identified beyond Osteichthyes, with the exception of three teeth in XUs 6 and 7 representing at least one wrasse (Labridae).

\section{Discussion}

Palaeoenvironmental and archaeological findings suggest that prior to the initial discard of cultural material at Murdumurdu (c.300 cal BP) the area was typified by a near-shore beach environment when the coastline was $100-150 \mathrm{~m}$ further inland c. 1000 years ago before the establishment of the modern dune system. The associated deposit is dominated by non-economic mollusc species, large amounts of shell hash, high rates of shell fragmentation, and low pollen concentrations (Mackenzie 2016; Moss et al. 2015; Peck 2016), indicating that deposition was associated with near-shore wave and aeolian processes. Pollen records show a mixed mangrove community dominated by Rhizophora sp. was present between 1250 and 850 cal BP, with back mangrove taxa including Ceriops/Bruguiera sp., Aegiceras corniculatum, Aviccenia marina and others (see Mackenzie 2016). A. corniculatum (the river mangrove) and other back mangrove types indicate a supratidal environment with freshwater input was present. The few economic shell specimens found in the upper units of this otherwise culturally sterile unit were likely either deposited by natural processes or filtered down the profile owing to taphonomic processes typical of mobile dune systems.
Continued progradation of the beach-ridge system led to conditions gradually shifting away from a near-shore beach environment towards the modern dune and swamp system. A combination of sea-level fall and progradation allowed intertidal and subtidal zones to expand, encouraging the development of littoral resources (Memmott et al. 2016; Moss et al. 2015). These changes also impacted Marralda Swamp, which became a freshwater wetland c. 400 cal BP after a long phase of brackish mangrove conditions (Mackenzie 2016; Mackenzie et al. 2017; Moss et al. 2015). A combination of vegetation succession and freshwater availability may have acted as a catalyst for the establishment of occupation sites along the coastal fringe of Marralda Swamp, including at Murdumurdu.

The cultural deposit is dominated by six species, four of which are common to both Squares A and B - hiant venus clams (M. hiantina), top shells (Calliostoma sp.), script venus clams (C. scripta) and cerithid snails (Cerithidea sp.). Square A also contains high numbers of tumid venus clams ( $G$. pectinatum) while Square B has strong representation of limpets (Patellidae). M. hiantina is the dominant species in both squares, while only Square A has G. pectinatum. Calliostoma sp. and Cerithidea sp. numbers decline through time as larger taxa become more prevalent in more recent times. These results suggest that the same species were being foraged from the local area and with a broad diet breadth. There does not appear to have been any adverse effects of intensive exploitation on the size of M. hiantina.

The majority of cultural material from both excavation squares is associated with a dense lens of shell, with radiocarbon ages indicating deposition occurring c. 300 cal BP (Figure 22). Low magnetic susceptibility values in lower units support an absence of cultural deposition before this time. The record during the period of occupation is dominated by important economic species (M. hiantina and G. pectinatum) from adjacent intertidal and subtidal zones, indicating highly targeted exploitation. This coincides with the deposition of the majority of the fish bone assemblage providing additional evidence for a period of site use. The timing of occupation at Murdumurdu appears to be closely linked to seasonal climatic cycles with stable isotopes from molluscan shell indicating site use exclusive to dry season conditions. Ethnographies associated with Aboriginal groups living along Australia's tropical north coast highlight heightened mobility as a key dry season behaviour (e.g. Davies 1985; Meehan 1982; Memmott 2010:20-21). While there is no ethnographic evidence of similar patterns associated with the Kaiadilt, widespread flooding across the wet season makes movement across the landscape more difficult. More widespread use of the landscape might be expected to be associated with the dry season when movement was less constrained. Given the presence of a short radiocarbon chronology, targeted resource exploitation, consolidated archaeological assemblage, and strong association with seasonal patterns, it is posited that the cultural deposition at Murdumurdu represents a short period of occupation with highly targeted exploitation of surrounding resources. However, the limited record makes it difficult to discern whether material was accumulated during a single deposition event or over several discrete episodes. However, the absence of G. pectinatum from Square B might indicate targeting of different patches in different foraging events. 


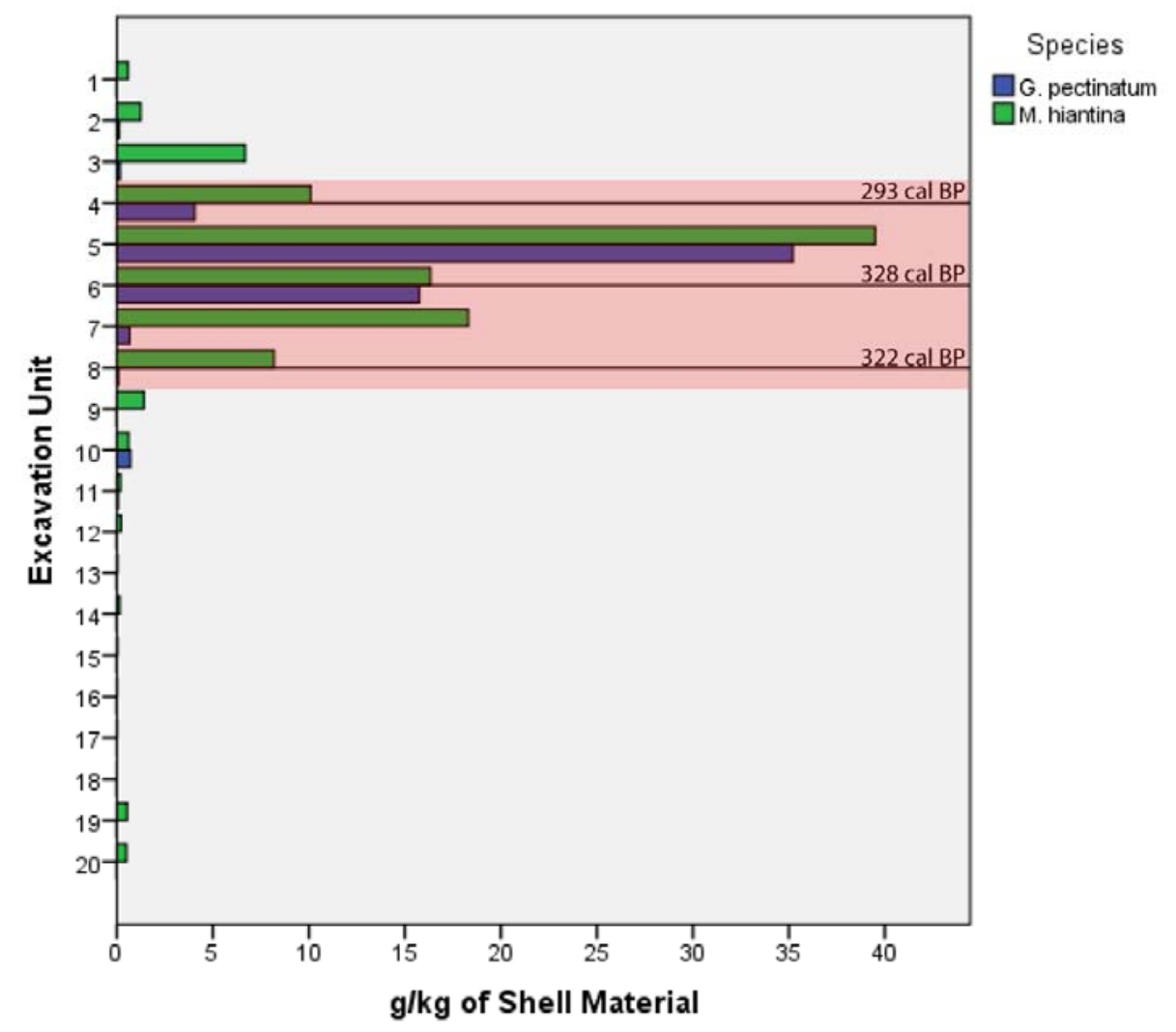

Figure 22. Density of shell material for combined Squares A and B. The highest $\mathrm{g} / \mathrm{kg}$ of G. pectinatum and M. hiantina correspond to intensive exploitation highlighted in pink. Radiocarbon dates indicate that this depositional event occurred over a short period of time.

Subsequent to XU4 (293 cal BP) evidence of site-use diminishes significantly. Total $\mathrm{g} / \mathrm{kg}$ of shell weight sees substantial decreases between XU4 and XU3 and again in XU2, suggesting a decrease or truncation of occupation (Figures 12 and 22). While cultural materials, such as whole and fragmented $M$. hiantina and G. pectinatum valves, and finfish remains are present within the top three XUs, the limited assemblage is likely associated with bioturbation of the near-surface dense shell lens deposits.

While an understanding of why Murdumurdu was used and abandoned is currently unclear, there are a number of likely contributing factors. Murdumurdu is just one place in a broad landscape exhibiting broadly similar attributes between Marralda Swamp and the adjacent coastline, suggesting that people likely camped in different locations along the ridge systems at different times. Other sites may have proven more viable or closer to important resources at particular times, including mangrove species that became increasingly important in the last 200-300 years (Peck 2016; Rosendahl et al. 2014a), encouraging the use of other areas. The occupation of Murdumurdu is part of a widespread pattern of increase in rates of site establishment from 700 years ago, which further accelerates in the last 300 years (Memmott et al. 2016). The short duration and relatively low faunal diversity recorded at Murdumurdu is consistent with short-term use of the area by foraging parties, described by Meehan (1982) as short-term 'dinnertime' camps. Ethnohistoric descriptions of Kaiadilt camps (such as that quoted from Roth 1901 above) demonstrate a very limited range of non-fibre objects in use very few of which are likely to survive to excavation in a humid tropical environment (see Figure 23). The deposits at Murdumurdu contrast starkly with the dense and more diverse deposits at Thundiy revealing repeated occupation over a large area over the last 700 years (see Moss et al. in press; Nagel et al. 2016).

Finally, the cessation in occupation at Murdumurdu broadly aligns with the arrival of foreign parties (i.e. Macassans and later Europeans) in the South Wellesley Islands. The close proximity of Macassan trapanging operations on Fowler Island (Oertle et al. 2014) and the later European occupation of Fowler and Sweers Islands (Laurie 1866; Tindale 1962a, 1962b) likely disrupted the scheduling of Kaiadilt activities along the south coast of Bentinck Island, including at Murdumurdu.

\section{Conclusion}

Excavations at the shell matrix site of Murdumurdu revealed a $30-40 \mathrm{~cm}$ thick deposit of cultural shell, bone, and charcoal, resting on degrading beach sands. An intensive, although short, period of occupation occurred c.300 cal BP, before diminishing in the more recent past. Site use is focused exclusively on dry season conditions, suggesting targeted exploitation of resources. Molluscs were collected from a variety of different habitats, including sandy-mud flats, rocky reefs, and mangroves and tidal-mud flats. While reasons behind patterns of occupation at Murdumurdu remain unclear evidence suggests that a variety of considerations may have influenced Kaiadilt use of this site, leading to a short albeit intense period of use. 


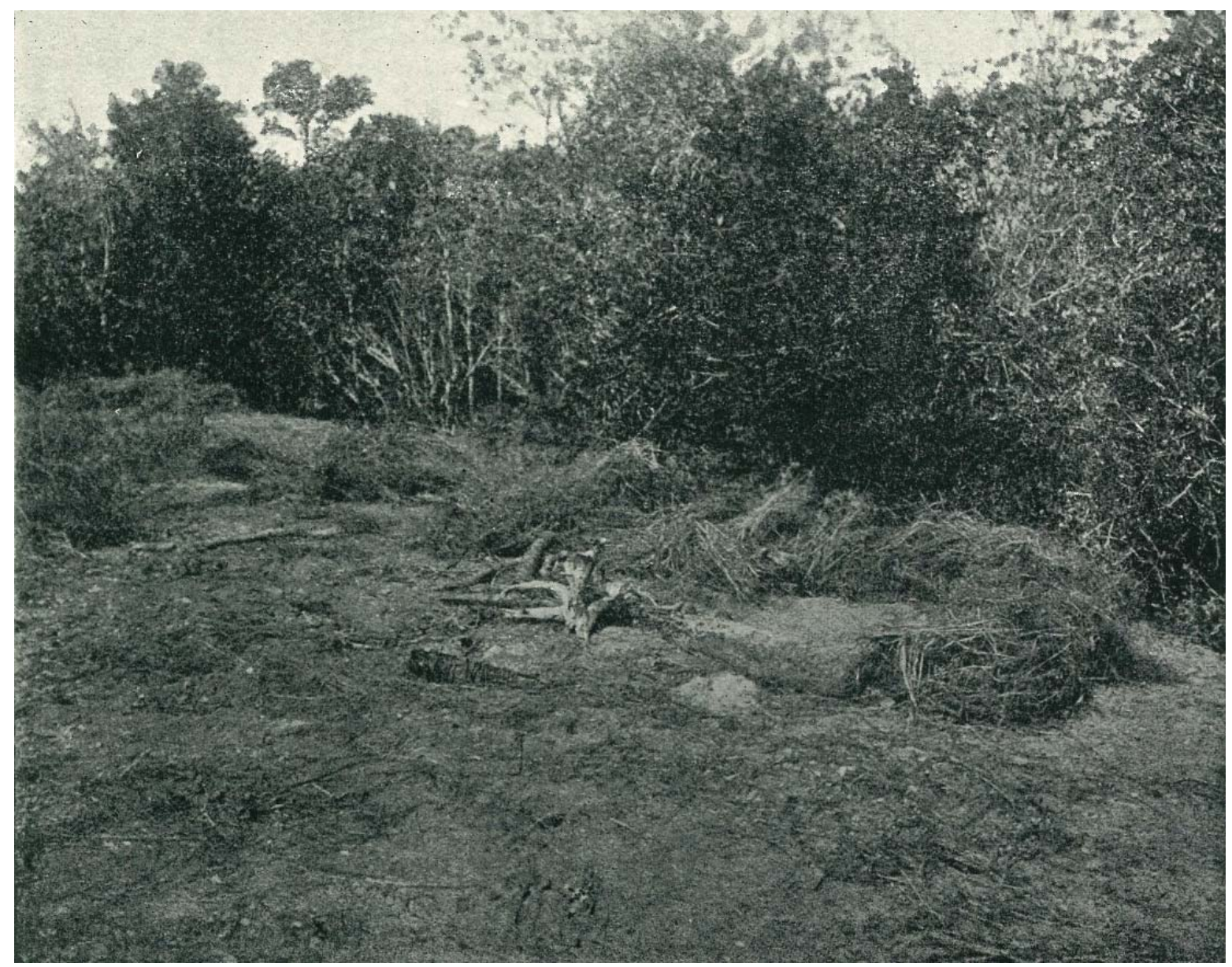

Figure 23. Photograph of Kaiadilt camp in the Marralda Swamp area taken by Jackson (1902:Plate VII).

\section{Acknowledgements}

A version of this paper appeared as a chapter in Helene Peck's (2016) $\mathrm{PhD}$ thesis. It is published here with consent, although Peck does not wish to be named as an author. This research was supported under the Australian Research Council's Discovery Projects funding scheme (project number DP120103179). SU is the recipient of an Australian Research Council Future Fellowship (FT120100656). Work on this paper was undertaken while SU was visiting as an Honorary Fellow in the School of Social Sciences, The University of Western Australia. We acknowledge Kaiadilt traditional owners of the South Wellesley Islands as partners in this research. The Kaiadilt Aboriginal Corporation collaborated in establishing the research framework for this project and have approved publication of this research. We extend a special thanks to Duncan Kelly, Samantha Aird, Texas Nagel, Annette Oerle, Emma Oliver, Helene Peck, Daniel Rosendahl and Lincoln Steinberger for assistance in the field. Thanks go to Rene Simpson for assistance with field logistics.

\section{References}

Bronk Ramsey, C. 2009 Bayesian analysis of radiocarbon dates. Radiocarbon 51(1):337-360. https://doi.org/10.1017/S003382220 $\underline{0033865}$

Dalan, R.A. and S.K. Banerjee 1998 Solving archaeological problems using techniques of soil magnetism. Geoarchaeology 13:3-36. https://doi.org/10.1002/(SICI)1520-6548(199801)13:1<3:: AID-GEA2 $>3.0 . \mathrm{CO} ; 2-9$

Davies, S. 1985 Aboriginal knowledge and use of the coast and sea in northern Arnhem Land. Coasts and Tidal Wetlands of the Australian Monsoon Region 1:297-312.
Dearing, J.A., K.L. Hay, S.M.J. Baban, A.S. Huddleston, E.M.H. Wellington and P.J. Loveland 1996 Magnetic susceptibility of soil: An evaluation of conflicting theories using a national data set. Geophysical Journal International 127(3):728-734. https://doi.org/ 10.1111/j.1365-246X.1996.tb04051.x

Ellwood, B.B., K.M. Petruso, F.B. Harrold and J. Schuldenrein 1997 High-resolution paleoclimatic trends for the Holocene identified using magnetic susceptibility data from archaeological excavations in caves. Journal of Archaeological Science 24(6):569-573. https:// doi.org/10.1006/jasc.1996.0140

Evans, N. 1992 Kayardild Dictionary and Thesaurus: A Vocabulary of the Language of the Bentinck Islanders, North-West Queensland. Parkville, VIC: Department of Linguistics and Language Studies, University of Melbourne.

Friedman, G.M. 1959 Identification of carbonate minerals by staining methods. Journal of Sedimentary Petrology 29(1):87-97. https://doi.org/10.1306/74D70894-2B21-11D7-8648000102C $\underline{1865 \mathrm{D}}$

Herries, A.I.R. and E.C. Fisher 2010 Multidimensional GIS modeling of magnetic mineralogy as a proxy for fire use and spatial patterning: Evidence from the Middle Stone Age bearing sea cave of Pinnacle Point 13B (Western Cape, South Africa). Journal of Human Evolution 59(3-4):306-320. $\quad$ https://doi.org/10.1016/j.jhevol. $\underline{2010.07 .012}$

Hoffman, E.J. 2011 Adopting a Geoarchaeological Approach to Understanding Shell Mound Formation in Weipa, Cape York, Australia. Unpublished BA (Hons) thesis, University of Auckland, Auckland. 
Jackson, C.F.V. 1902 Report on a Visit to the West Coast of the Cape York Peninsula and Some Islands of the Gulf of Carpentaria. Queensland Department of Mines Geological Survey Report 180. Brisbane: George Arthur Vaughan, Government Printer.

Laurie, J.S. 1866 Landsborough's Exploration of Australia from Carpentaria to Melbourne. London: J. Marshall \& F. Laurie.

Lees, B.G. 1987 Age structure of the Point Stuart chenier plain: A reassessment. Search 18:257-259.

Lees, B.G., L. Yanchou and J. Head 1990 Reconnaissance thermoluminescence dating of northern Australian coastal dune systems. Quaternary Research 34(2):169-185. https://doi.org/ $\underline{\text { 10.1016/0033-5894(90)90029-K }}$

Linford, N., P. Linford and E. Platzman 2005 Dating environmental change using magnetic bacteria in archaeological soils from the upper Thames Valley, UK. Journal of Archaeological Science 32(7):1037-1043. https://doi.org/10.1016/j.jas.2005.01.017

Mackenzie, L. 2016 Palaeoecology of the South Wellesley Archipelago: A History of Human Occupation and Environmental Change. Unpublished PhD thesis, The University of Queensland, Brisbane.

Mackenzie, L., H. Heijnis, P. Gadd, P. Moss and J. Shulmeister 2017 Geochemical investigation of the South Wellesley Island wetlands: Insight into wetland development during the Holocene in tropical northern Australia. The Holocene 27(4):566-578. https://doi.org/ $\underline{10.1177 / 0959683616670219}$

Maher, B.A. 1986 Characterisation of soils by mineral magnetic measurements. Physics of the Earth and Planetary Interiors 42(12):76-92. https://doi.org/10.1016/S0031-9201(86)80010-3

Meehan, B. 1982 Shell Bed to Shell Midden. Canberra: Australian Institute of Aboriginal Studies.

Memmott, P. 2010 Material Culture of the North Wellesley Islands. Brisbane: Aboriginal and Torres Strait Islander Studies Unit, The University of Queensland.

Memmott, P., E. Round, D. Rosendahl and S. Ulm 2016 Fission, fusion and syncretism: Linguistic and environmental changes amongst the Tangkic people of the southern Gulf of Carpentaria, northern Australia. In J-C. Verstraete and D. Hafner (eds), Land and Language in Cape York Peninsula and the Gulf Country, pp.105136. Culture and Language Use 18. Amsterdam: John Benjamins Publishing Company. https://doi.org/10.1075/clu.18.06mem

Moss, P., L. Mackenzie, S. Ulm, C. Sloss, D. Rosendahl, L. Petherick, L. Steinberger, L. Wallis, H. Heijnis, F. Petchey and G. Jacobsen 2015 Environmental context for late Holocene human occupation of the South Wellesley Archipelago, Gulf of Carpentaria, northern Australia. Quaternary International 385:136-144. https://doi.org/10.1016/j.quaint.2015.02.051

Moss, P.T., S. Ulm, L. Mackenzie, L.A. Wallis, D. Rosendahl and L. Steinberger in press Robust local vegetation records from dense archaeological shell matrixes: A palynological analysis of the Thundiy shell deposit, Bentinck Island, Gulf of Carpentaria, Australia. Archaeological and Anthropological Sciences. https://doi.org/10.1007/s12520-016-0394-0

Nagel, T., D. Rosendahl, Q. Hua, P. Moss, C. Sloss, F. Petchey and S. Ulm 2016 Extended residence times for foraminifera in a marineinfluenced terrestrial archaeological deposit and implications for palaeoenvironmental reconstruction. Journal of Archaeological Science: Reports 5:25-34. https://doi.org/10.1016/j.jasrep.2015. $\underline{11.008}$

O'Connor, S. 2016 A Geomorphological Study of the South Wellesley Islands, Southern Gulf of Carpentaria. Unpublished MSc thesis, Queensland University of Technology, Brisbane.
Oertle, A., M. Leavesley, S. Ulm, G. Mate and D. Rosendahl 2014 At the margins: Archaeological evidence for Macassan activities in the South Wellesley Islands, Gulf of Carpentaria. Australasian Historical Archaeology 32:64-71.

Peck, H. 2016 The Application of Ecological Models and Trophic Analyses to Archaeological Marine Fauna Assemblages: Towards Improved Understanding of Prehistoric Marine Fisheries and Ecosystems in Tropical Australia. Unpublished $\mathrm{PhD}$ thesis, James Cook University, Cairns.

Petchey, F., S. Ulm, B. David, I.J. McNiven, B. Asmussen, H. Tomkins, N. Dolby, K. Aplin, T. Richards, C. Rowe, M. Leavesley and $\mathrm{H}$. Mandui 2013 High-resolution radiocarbon dating of marine materials in archaeological contexts: Radiocarbon marine reservoir variability between Anadara, Gafrarium, Batissa, Polymesoda spp. and Echinoidea at Caution Bay, southern coastal Papua New Guinea. Archaeological and Anthropological Sciences 5(1):69-80. https:// doi.org/10.1007/s12520-012-0108-1

Reimer, P.J., E. Bard, A. Bayliss, J.W. Beck, P.G. Blackwell, C. Bronk Ramsey, C.E. Buck, H. Cheng, R.L. Edwards, M. Friedrich, P.M. Grootes, T.P. Guilderson, H. Haflidason, I. Hajdas, C. Hatté, T.J. Heaton, D.L. Hoffmann, A.G. Hogg, K.A. Hughen, K.F. Kaiser, B. Kromer, S.W. Manning. M. Niu, R.W. Reimer, D.A. Richards, E.M. Scott, J.R. Southon, R.A. Staff, C.S.M. Turney and J. van der Plicht 2013 IntCal13 and Marine13 radiocarbon age calibration curves 0-50,000 years cal BP. Radiocarbon 55(4):1869-1887. https://doi.org/10.2458/azu is_rc.55.16947

Reitz, E.J. and E.S. Wing 2008 Zooarchaeology. 2nd ed. Cambridge: Cambridge University Press. https://doi.org/10.1017/CBO $\underline{9780511841354}$

Rosendahl, D., K.M. Lowe, L.A. Wallis and S. Ulm 2014b Integrating geoarchaeology and magnetic susceptibility at three shell mounds: A pilot study from Mornington Island, Gulf of Carpentaria, Australia. Journal of Archaeological Science 49:21-32. https://doi.org/10.1016/j.jas.2014.04.017

Rosendahl, D., S. Ulm, H. Tomkins, L. Wallis and P. Memmott 2014a Late Holocene changes in shellfishing behaviors from the Gulf of Carpentaria, northern Australia. Journal of Island and Coastal Archaeology 9:253-267. https://doi.org/10.1080/15564894. $\underline{2014.880757}$

Roth, W.E. 1901 Carpentaria Blacks 1: The Wellesley Islands. The Brisbane Courier 24 August, p.13.

Roth, W.E. 1903 Dr Roth's Visit to the Wellesley Islands: Report to the Under Secretary, Department of Public Lands. Office of the Northern Protector of Aboriginals.

Shulmeister, J. and B.G. Lees 1992 Morphology and chronostratigraphy of a coastal dunefield; Groote Eylandt, northern Australia. Geomorphology 5(6):521-534. https://doi.org/10.1016/ 0169-555X(92)90023-H

Thompson, R. and F. Oldfield 1986 Environmental Magnetism. London: Allen and Unwin. https://doi.org/10.1007/978-94-011$\underline{\text { 8036-8 }}$

Tindale, N.B. 1962a Geographical knowledge of the Kaiadilt people of Bentinck Island, Queensland. Records of the South Australian Museum 14(2):259-297.

Tindale, N.B. 1962b Some population changes among the Kaiadilt people of Bentinck Island, Queensland. Records of the South Australian Museum 14(2):297-336.

Tomkins, H., D. Rosendahl and S. Ulm 2013 Tropical Archaeology Research Laboratory Comparative Fish Reference Collection: Developing a resource for identifying marine fish remains in archaeological deposits in tropical Australasia. Queensland Archaeological Research 16:1-13. https://doi.org/10.25120/ qar.16.2013.220 
Twaddle, R. 2016 A Novel Application of Sclerochronology and Scleroisotope Analysis: Forging New Understandings of Aboriginal Occupation in the South Wellesley Archipelago, Gulf of Carpentaria. Unpublished $\mathrm{PhD}$ thesis, James Cook University, Cairns.

Ulm, S., N. Evans, D. Rosendahl, P. Memmott and F. Petchey 2010 Radiocarbon and linguistic dates for occupation of the South Wellesley Islands, northern Australia. Archaeology in Oceania 45(1):39-43. https://doi.org/10.1002/j.1834-4453.2010.tb00076.x

Ulm S., F. Petchey, G.E. Jacobsen and D. Rosendahl in prep. Prebomb marine radiocarbon reservoir variability in the eastern Gulf of Carpentaria, Queensland, Australia. Queensland Archaeological Research.
Citation: Twaddle, R.W., C.R. Sloss, K.M. Lowe, P. Moss, L.L. Mackenzie and S. Ulm 2017 Short-term late Holocene dry season occupation and sandy-mud flat focused foraging at Murdumurdu, Bentinck Island, Gulf of Carpentaria. Queensland Archaeological Research 20:9-46. https://doi.org/10.25120/qar.17.2017.3588 
Appendix A. Summary excavation data and retained materials, Murdumurdu, Square A. Note values reported here supersede those reported in Peck (2016).

\begin{tabular}{|c|c|c|c|c|c|c|c|c|c|c|c|c|c|c|c|}
\hline$\not$ & 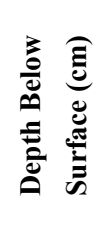 & 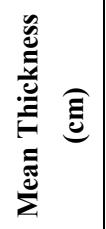 & 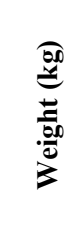 & 胥 & 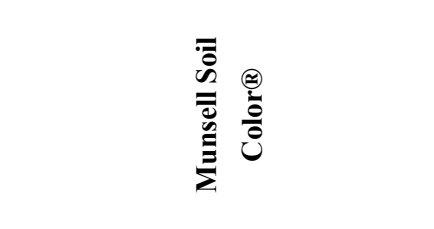 & $\frac{\pi}{2}$ & 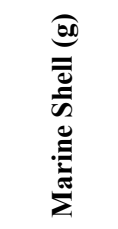 & 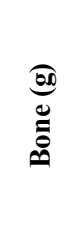 & 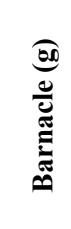 & 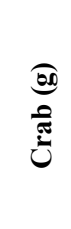 & 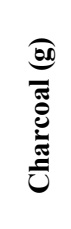 & 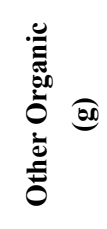 & 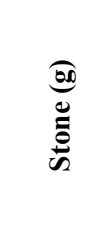 & 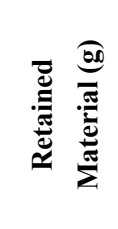 & 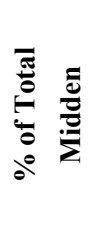 \\
\hline 1 & 2.46 & 2.46 & 18.7 & 0.25 & 7.5YR 5/4 Brown & 10.0 & 39.92 & 0.05 & 0.11 & 0.00 & 0.03 & 49.17 & 5.25 & 94.53 & 0.51 \\
\hline 2 & 6.36 & 3.90 & 13.1 & 0.25 & 7.5YR 5/4 Brown & 8.5 & 17.92 & 0.12 & 0.17 & 0.09 & 0.00 & 12.31 & 0.29 & 30.90 & 0.24 \\
\hline 3 & 9.30 & 2.94 & 12.2 & 0.25 & 7.5YR 5/4 Brown & 9.5 & 141.95 & 0.20 & 0.10 & 0.19 & 0.06 & 6.15 & 7.69 & 156.34 & 1.28 \\
\hline 4 & 12.34 & 3.04 & 10.8 & 0.25 & 7.5YR 5/4 Brown & 8.0 & 128.08 & 0.37 & 0.23 & 0.39 & 0.11 & 5.64 & 11.05 & 145.87 & 1.35 \\
\hline 5 & 15.44 & 3.10 & 11.5 & 0.25 & 7.5YR 5/4 Brown & 8.0 & 1423.94 & 0.28 & 0.28 & 0.78 & 0.33 & 4.97 & 21.92 & 1452.50 & 12.63 \\
\hline 6 & 18.32 & 2.88 & 12.0 & 0.25 & 7.5YR 5/4 Brown & 8.5 & 653.38 & 0.34 & 0.00 & 0.00 & 0.05 & 2.01 & 7.78 & 663.56 & 5.53 \\
\hline 7 & 21.54 & 3.22 & 12.3 & 0.25 & 7.5YR 5/3 Brown & 9.5 & 76.65 & 0.01 & 0.06 & 0.09 & 0.17 & 3.91 & 11.34 & 92.23 & 0.75 \\
\hline 8 & 24.42 & 2.88 & 10.5 & 0.25 & 7.5YR 5/4 Brown & 8.5 & 36.48 & 0.04 & 0.05 & 0.13 & 0.08 & 2.20 & 6.49 & 45.47 & 0.43 \\
\hline 9 & 27.60 & 3.18 & 11.8 & 0.25 & 7.5YR 5/4 Brown & 8.5 & 22.89 & 0.04 & 0.21 & 0.04 & 0.08 & 2.50 & 3.56 & 29.32 & 0.25 \\
\hline 10 & 31.36 & 3.76 & 12.9 & 0.25 & 7.5YR 5/4 Brown & 8.5 & 43.50 & 0.00 & 0.05 & 0.13 & 0.05 & 1.29 & 2.79 & 47.81 & 0.37 \\
\hline 11 & 34.32 & 2.96 & 11.4 & 0.25 & 7.5YR 5/4 Brown & 8.5 & 19.48 & 0.00 & 0.10 & 0.00 & 0.02 & 1.52 & 2.19 & 23.31 & 0.20 \\
\hline 12 & 37.40 & 3.08 & 12.2 & 0.25 & 7.5YR 5/4 Brown & 7.5 & 22.30 & 0.00 & 0.00 & 0.00 & 0.00 & 1.07 & 1.81 & 25.18 & 0.21 \\
\hline 13 & 40.00 & 2.60 & 12.7 & 0.25 & 7.5YR 6/4 Light Brown & 8.0 & 19.77 & 0.00 & 0.16 & 0.00 & 0.00 & 1.68 & 1.45 & 23.06 & 0.18 \\
\hline 14 & 43.36 & 3.36 & 10.6 & 0.25 & 7.5YR 5/6 Strong Brown & 8.5 & 19.89 & 0.00 & 0.15 & 0.00 & 0.00 & 0.93 & 1.27 & 22.24 & 0.21 \\
\hline 15 & 46.36 & 3.00 & 11.2 & 0.25 & 7.5YR 6/4 Light Brown & 8.0 & 21.66 & 0.00 & 0.17 & 0.00 & 0.03 & 1.14 & 2.25 & 25.25 & 0.23 \\
\hline 16 & 49.34 & 2.98 & 10.6 & 0.25 & 7.5YR 6/4 Light Brown & 9.0 & 36.01 & 0.00 & 0.21 & 0.00 & 0.12 & 1.21 & 4.88 & 42.43 & 0.40 \\
\hline 17 & 52.40 & 3.06 & 12.2 & 0.25 & 7.5YR 6/4 Light Brown & 8.0 & 42.19 & 0.00 & 0.45 & 0.00 & 0.00 & 0.85 & 6.04 & 49.53 & 0.41 \\
\hline 18 & 55.24 & 2.84 & 10.0 & 0.25 & 7.5YR 6/6 Reddish Yellow Brown & 8.0 & 77.04 & 0.00 & 0.66 & 0.10 & 0.00 & 1.05 & 17.25 & 96.10 & 0.96 \\
\hline 19 & 58.40 & 3.16 & 10.8 & 0.25 & 7.5YR 6/6 Reddish Yellow & 8.0 & 146.13 & 0.00 & 1.23 & 0.00 & 0.00 & 1.77 & 37.09 & 186.22 & 1.72 \\
\hline 20 & 61.36 & 2.96 & 11.7 & 0.25 & 7.5YR 6/6 Reddish Yellow & 8.0 & 239.28 & 0.00 & 4.25 & 0.14 & 0.01 & 1.66 & 69.10 & 312.44 & 2.67 \\
\hline Total & - & 61.36 & 239.2 & - & - & - & 3228.46 & 1.45 & 8.64 & 2.08 & 1.14 & 103.03 & 221.10 & 3566.29 & 1.49 \\
\hline
\end{tabular}


Appendix B. Summary excavation data and retained materials, Murdumurdu, Square B. Note values reported here supersede those reported in Peck (2016).

\begin{tabular}{|c|c|c|c|c|c|c|c|c|c|c|c|c|c|c|c|}
\hline$\vec{x}$ & 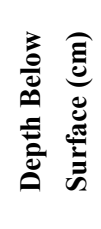 & 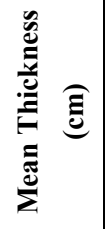 & 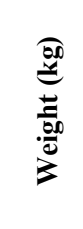 & 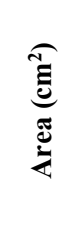 & 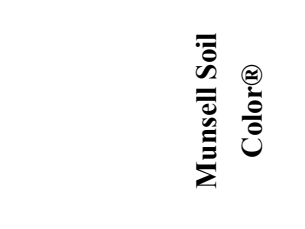 & $\frac{\pi}{2}$ & 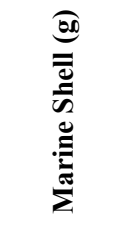 & 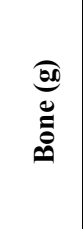 & 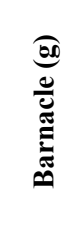 & 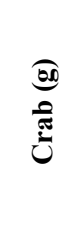 & 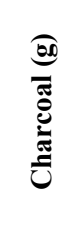 & 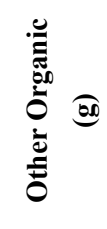 & $\begin{array}{l}\text { ब0, } \\
\stackrel{0}{0} \\
\stackrel{\overrightarrow{0}}{\omega}\end{array}$ & 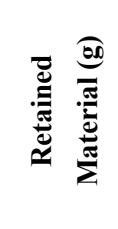 & 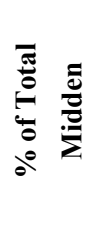 \\
\hline 1 & 3.64 & 3.64 & 13.2 & 0.25 & 7.5YR 5/4 Brown & 8.0 & 29.30 & 0.01 & 0.00 & 0.00 & 0.00 & 42.69 & 2.63 & 74.63 & 0.57 \\
\hline 2 & 6.42 & 2.78 & 11.0 & 0.25 & 7.5YR 5/4 Brown & 8.0 & 42.18 & 0.03 & 0.06 & 0.05 & 0.01 & 5.70 & 5.03 & 53.06 & 0.48 \\
\hline 3 & 9.94 & 3.52 & 13.4 & 0.25 & 7.5YR 5/4 Brown & 9.0 & 78.21 & 0.03 & 0.19 & 0.00 & 0.03 & 10.38 & 10.72 & 99.56 & 0.74 \\
\hline 4 & 12.46 & 2.52 & 8.9 & 0.25 & 7.5YR 5/4 Brown & 9.0 & 207.37 & 0.05 & 0.02 & 0.00 & 0.01 & 6.63 & 7.95 & 222.03 & 2.49 \\
\hline 5 & 15.46 & 3.00 & 12.4 & 0.25 & 7.5YR 4/4 Brown & 9.0 & 386.54 & 0.07 & 0.34 & 0.07 & 0.00 & 8.39 & 12.37 & 407.78 & 3.29 \\
\hline 6 & 18.74 & 3.28 & 19.0 & 0.25 & 7.5YR 4/4 Brown & 9.0 & 263.94 & 0.11 & 0.13 & 0.00 & 0.07 & 7.47 & 13.43 & 285.15 & 1.50 \\
\hline 7 & 21.60 & 2.86 & 11.4 & 0.25 & 7.5YR 4/4 Brown & 9.0 & 419.14 & 0.06 & 0.09 & 0.00 & 0.17 & 5.33 & 13.45 & 438.24 & 3.84 \\
\hline 8 & 24.66 & 3.06 & 12.4 & 0.25 & 7.5YR 5/4 Brown & 9.0 & 228.62 & 0.08 & 0.57 & 0.01 & 0.14 & 5.46 & 18.05 & 252.93 & 2.04 \\
\hline 9 & 27.84 & 3.18 & 13.0 & 0.25 & 7.5YR 5/4 Brown & 8.5 & 66.15 & 0.01 & 0.25 & 0.00 & 0.21 & 4.80 & 10.12 & 81.54 & 0.63 \\
\hline 10 & 30.92 & 3.08 & 12.1 & 0.25 & 7.5YR 5/4 Brown & 8.5 & 35.78 & 0.00 & 0.20 & 0.01 & 0.00 & 5.27 & 6.94 & 48.20 & 0.40 \\
\hline 11 & 33.48 & 2.56 & 9.9 & 0.25 & 7.5YR 5/4 Brown & 8.5 & 25.42 & 0.00 & 0.35 & 0.00 & 0.00 & 3.54 & 5.32 & 34.63 & 0.35 \\
\hline 12 & 36.62 & 3.14 & 13.2 & 0.25 & 7.5YR 6/4 Light Brown & 9.0 & 29.14 & 0.00 & 0.31 & 0.00 & 0.00 & 4.58 & 5.02 & 39.05 & 0.30 \\
\hline 13 & 40.26 & 3.64 & 13.4 & 0.25 & 7.5YR 6/4 Light Brown & 9.5 & 31.70 & 0.00 & 0.31 & 0.07 & 0.00 & 4.22 & 3.17 & 39.47 & 0.29 \\
\hline 14 & 42.60 & 2.34 & 9.1 & 0.25 & 7.5YR 6/4 Light Brown & 9.0 & 17.66 & 0.00 & 0.22 & 0.00 & 0.00 & 3.04 & 1.57 & 22.49 & 0.25 \\
\hline 15 & 45.66 & 3.06 & 13.3 & 0.25 & 7.5YR 6/4 Light Brown & 9.0 & 33.88 & 0.00 & 0.38 & 0.01 & 0.01 & 111.94 & 2.49 & 148.71 & 1.50 \\
\hline 16 & 48.58 & 2.92 & 12.3 & 0.25 & 7.5YR 6/4 Light Brown & 9.0 & 39.48 & 0.00 & 1.07 & 0.06 & 0.00 & 5.82 & 4.09 & 50.52 & 0.41 \\
\hline 17 & 51.60 & 3.02 & 12.8 & 0.25 & 7.5YR 7/4 Pink & 9.0 & 41.52 & 0.00 & 0.38 & 0.00 & 0.00 & 3.44 & 4.51 & 49.85 & 0.39 \\
\hline 18 & 54.68 & 3.08 & 12.5 & 0.25 & 7.5YR 7/4 Pink & 9.0 & 28.57 & 0.00 & 0.38 & 0.01 & 0.00 & 6.19 & 2.74 & 37.89 & 0.30 \\
\hline 19 & 57.58 & 2.90 & 11.3 & 0.25 & 7.5YR 7/4 Pink & 9.0 & 19.90 & 0.00 & 0.31 & 0.04 & 0.00 & 4.34 & 3.26 & 27.85 & 0.25 \\
\hline 20 & 60.68 & 3.10 & 12.4 & 0.25 & 7.5YR 7/4 Pink & 9.0 & 25.77 & 0.00 & 0.23 & 0.00 & 0.00 & 3.76 & 1.85 & 31.61 & 0.25 \\
\hline Total & - & 60.68 & 246.0 & - & - & - & 2050.27 & 0.45 & 5.79 & $\mathbf{0 . 3 3}$ & 0.65 & 252.99 & 134.71 & 2445.19 & 1.01 \\
\hline
\end{tabular}


Appendix C. Molluscan taxa MNI per XU, Murdumurdu, Square A.

\begin{tabular}{|c|c|c|c|c|c|c|c|c|c|c|c|c|c|c|c|c|c|c|c|c|c|}
\hline Taxon & 1 & 2 & 3 & 4 & 5 & 6 & 7 & 8 & 9 & 10 & 11 & 12 & 13 & 14 & 15 & 16 & 17 & 18 & 19 & 20 & Total \\
\hline \multicolumn{22}{|l|}{ MARINE BIVALVIA } \\
\hline Circe scripta & & & & 6 & 7 & 7 & & 1 & & & & & 1 & & & & & 2 & 4 & 9 & 37 \\
\hline Corbula fortisulcata & & & & & & 1 & & & & & & & & & & & & & 1 & 1 & 3 \\
\hline Gafrarium pectinatum & & & & 3 & 39 & 26 & 1 & & & 1 & & & & & & & & & & & 70 \\
\hline Glauconome virens & & & & & & & & & & & & & & & & & & & 1 & & 1 \\
\hline Lunulicardia hemicardium & & & & & & 2 & 2 & & & & & & & 1 & & & & & & 4 & 9 \\
\hline Mactra sp. & & & & 1 & & & & & & & & & & & & & & & & & 1 \\
\hline Marcia hiantina & & & 20 & 67 & 90 & 47 & 3 & 2 & 1 & & & & & & 1 & & & & 1 & 2 & 234 \\
\hline Mytilidae & & & & & & & & & & & & & & & 1 & & & & & & 1 \\
\hline Placamen retroversum & 6 & & & & & & & & & & & & & & & & 1 & & & & 7 \\
\hline Placuna placenta & & & 1 & & & & & & & & & & & & & & & & & & 1 \\
\hline Saccostrea glomerata & & & & & & & & & & 2 & & 1 & & & & & & & & 3 & 6 \\
\hline Tellina sp. & & & 1 & & & & & & & & & & & & 1 & & 1 & & & 2 & 5 \\
\hline \multicolumn{22}{|l|}{ MARINE GASTROPODA } \\
\hline Calliostoma sp. & 3 & & 9 & 4 & 7 & 5 & 6 & 4 & 6 & 6 & 2 & 6 & 10 & 4 & 3 & 10 & 13 & 16 & 23 & 41 & 178 \\
\hline Pirenella cingulata & & & & & & & & & & & & & & & & & & & & 1 & 1 \\
\hline Cerithidea sp. & & & 2 & & 2 & 2 & & & & & 4 & & & & & & & 6 & 10 & & 26 \\
\hline Clypeomorus sp. & & & & & & & & & & & & & & & & & & & & 1 & 1 \\
\hline Mitrella scripta & & & & & 1 & & & & & & & & & & & & & & & 1 & 2 \\
\hline Nassarius sp. & & & & & 1 & & & & & & & & & & & & & & & & 1 \\
\hline Patellidae & & & 1 & & & & & & 1 & 1 & & 2 & & & & & & & & & 5 \\
\hline Rhinoclavis sp. & & & & & & & & & & & & & & & & & & & & 1 & 1 \\
\hline Turbo sp. & & 1 & & & & & & & & & & & & & & & & & & & 1 \\
\hline Total & 9 & 1 & 34 & 81 & 147 & 90 & 12 & 7 & 8 & 10 & 6 & 9 & 11 & 5 & 6 & 10 & 15 & 24 & 40 & 67 & 591 \\
\hline
\end{tabular}


Appendix D. Molluscan taxa weights (g) per XU, Murdumurdu, Square A.

\begin{tabular}{|c|c|c|c|c|c|c|c|c|c|c|}
\hline Taxon & 1 & 2 & 3 & 4 & 5 & 6 & 7 & 8 & 9 & 10 \\
\hline \multicolumn{11}{|l|}{ MARINE BIVALVIA } \\
\hline Asaphis violascens & 0.04 & & & & 0.44 & & & & 0.78 & \\
\hline \multicolumn{11}{|l|}{ Cardiidae } \\
\hline \multicolumn{11}{|l|}{ Chama sp. } \\
\hline Circe scripta & & & 0.70 & 3.89 & 5.44 & 3.45 & & 1.25 & & \\
\hline Corbula fortisulcata & & & & & & 0.22 & & & & 0.25 \\
\hline Gafrarium pectinatum & & 3.33 & 4.27 & 87.84 & 810.04 & 378.04 & 16.18 & 1.52 & & 18.18 \\
\hline Glauconome virens & & & & & 0.40 & & 0.27 & & & \\
\hline Lunulicardia hemicardium & & & & & 0.63 & 1.50 & & 0.09 & & \\
\hline Mactra sp. & & & & 4.27 & & & & & & \\
\hline Marcia hiantina & 2.28 & & 116.22 & & 579.56 & 242.88 & 32.37 & 7.65 & 4.55 & 6.08 \\
\hline Mytilidae & & & & & & & & 0.01 & & \\
\hline \multicolumn{11}{|l|}{ Pitar pellucidus } \\
\hline Placamen retroversum & 24.09 & & & & & & & & & \\
\hline Placuna placenta & & & 0.07 & & & 0.05 & & & & \\
\hline Saccostea glomerata & & 0.17 & & 0.13 & 0.70 & 1.02 & & 0.15 & & 0.18 \\
\hline Semele cordiformis & & & & & 1.30 & & & & & \\
\hline Tellina sp. & & & 0.09 & & & & & & & \\
\hline \multicolumn{11}{|l|}{ MARINE GASTROPODA } \\
\hline Calliostoma sp. & 0.06 & & 0.13 & 0.07 & 0.12 & 0.11 & 0.13 & 0.02 & 0.19 & 0.13 \\
\hline \multicolumn{11}{|l|}{ Pirenella cingulata } \\
\hline Cerithidea sp. & & & 0.06 & & 0.08 & 0.06 & & & & \\
\hline \multicolumn{11}{|l|}{ Clypeomorus sp. } \\
\hline Mitrella scripta & & & & & 0.09 & & & & & \\
\hline Nassarius sp. & & & & & 0.07 & & & & & \\
\hline Patellidae & & & 0.01 & & & & & & & 0.02 \\
\hline \multicolumn{11}{|l|}{ Rhinoclavis sp. } \\
\hline Turbo sp. & & 0.49 & & & & & & & & \\
\hline Volegalea cochlidium & & & & 4.52 & & & & & & \\
\hline Unidentified Shell & 13.45 & 13.93 & 20.40 & 27.36 & 25.07 & 26.05 & 27.68 & 25.79 & 17.37 & 18.66 \\
\hline Total & 39.92 & 17.92 & 141.95 & 128.08 & 1423.94 & 653.38 & 76.65 & 36.48 & 22.89 & 43.50 \\
\hline
\end{tabular}

Queensland Archaeological Research | Vol. 20 | 2017 | 35 
Appendix D. Molluscan taxa weights (g) per XU, Murdumurdu, Square A (cont).

\begin{tabular}{|c|c|c|c|c|c|c|c|c|c|c|c|}
\hline Taxon & 11 & 12 & 13 & 14 & 15 & 16 & 17 & 18 & 19 & 20 & Total \\
\hline \multicolumn{12}{|l|}{ MARINE BIVALVIA } \\
\hline Asaphis violascens & & & & & & & & & & 0.92 & 2.18 \\
\hline Chama sp. & & & & & & & & 0.03 & 0.78 & 0.23 & 1.04 \\
\hline Circe scripta & & & 0.17 & & & & & 0.34 & 3.42 & 4.35 & 23.01 \\
\hline Corbula fortisulcata & & & & & & & & & 0.21 & 0.13 & 0.81 \\
\hline Glauconome virens & & & & & & & & & & & 0.67 \\
\hline Lunulicardia hemicardium & & & & 0.06 & & & & 1.54 & 0.66 & 4.52 & 9.00 \\
\hline Mactra sp. & & & & & & & & & & & 4.27 \\
\hline Marcia hiantina & & 2.09 & & 0.42 & 0.44 & 0.29 & 0.31 & & 10.23 & 11.78 & 1017.15 \\
\hline Mytilidae & & & & & 0.06 & & & & & & 0.07 \\
\hline Saccostea glomerata & & 0.38 & & & 0.18 & & 0.03 & & 0.14 & 2.29 & 5.37 \\
\hline Semele cordiformis & & & & & & & & & & & 1.30 \\
\hline Tellina sp. & & & & 0.09 & & & 0.10 & & 0.79 & 1.25 & 2.32 \\
\hline \multicolumn{12}{|l|}{ MARINE GASTROPODA } \\
\hline Calliostoma sp. & 0.05 & 0.11 & 0.21 & 0.08 & 0.06 & 0.21 & 0.18 & 0.12 & 0.90 & 1.68 & 4.56 \\
\hline Pirenella cingulata & & & & & & & & & & 0.13 & 0.13 \\
\hline Cerithidea sp. & 0.14 & & & & & & & 0.10 & 0.66 & & 1.10 \\
\hline Clypeomorus sp. & & & & & & & & & & 0.16 & 0.16 \\
\hline Mitrella scripta & & & & & & & & & & 0.31 & 0.40 \\
\hline Nassarius sp. & & & & & & & & & & & 0.07 \\
\hline
\end{tabular}


Appendix E. Molluscan taxa MNI per XU, Murdumurdu, Square B.

\begin{tabular}{|c|c|c|c|c|c|c|c|c|c|c|c|c|c|c|c|c|c|c|c|c|c|}
\hline Taxon & 1 & 2 & 3 & 4 & 5 & 6 & 7 & 8 & 9 & 10 & 11 & 12 & 13 & 14 & 15 & 16 & 17 & 18 & 19 & 20 & Total \\
\hline \multicolumn{22}{|l|}{ MARINE BIVALVIA } \\
\hline Arca ventricosa & 1 & & & & & & & & & & & & & & & & & & & & 1 \\
\hline Asaphis violascens & & & & & & & & & & & & & & & & & & 1 & & & 1 \\
\hline Beguina semiorbiculata & 1 & & & & & & & & & & & & & & & & & & & & 1 \\
\hline Cardiidae & & & & & & & & & & & & & & & & & 1 & & & & 1 \\
\hline Chama sp. & & & & & & & & & & & & & 1 & & & & & & & & 1 \\
\hline Circe scripta & & & 1 & & 2 & 1 & & 2 & & 2 & & & 2 & & & & 1 & 1 & & & 12 \\
\hline Corbula fortisulcata & & & & & & & & & & & & & & & 1 & & & & & & 1 \\
\hline Lunulicardia hemicardium & & & & & & 1 & & & & & & 1 & & & 1 & & & 1 & & & 4 \\
\hline Mactra sp. & 1 & & & & & & & & & & & & & & & 1 & & & & & 2 \\
\hline Marcia hiantina & 2 & 2 & 10 & 28 & 63 & 44 & 54 & 32 & 5 & 1 & 1 & 1 & 1 & 1 & & & & & & & 245 \\
\hline Pinctada sp. & 1 & & & & & & & & & & & & & & & & & & & & 1 \\
\hline Saccostrea glomerata & & & & & & & & & & & & & & 1 & & 1 & 1 & 1 & & & 4 \\
\hline Tellina sp. & & & & & & & & & 1 & & & 1 & & & & & & & & & 2 \\
\hline \multicolumn{22}{|l|}{ MARINE GASTROPODA } \\
\hline Calliostoma sp. & 2 & 6 & 6 & 6 & 7 & 10 & 4 & 7 & 6 & 6 & 5 & 7 & 11 & 4 & 7 & 7 & 11 & 14 & 13 & 14 & 153 \\
\hline Cerithidea sp. & & & & 5 & 4 & & & & 1 & & 1 & & 4 & & & & & 2 & & 1 & 18 \\
\hline Clypeomorus sp. & & & & 1 & & & & & & & & & & & & & & & & & 1 \\
\hline Nassarius sp. & & & & & & & & & & & & & & & & & & & & 1 & 1 \\
\hline Patellidae & & & & & & & & 1 & & & 3 & & 3 & & & & 2 & 1 & 2 & & 12 \\
\hline Rhinoclovis sp. & & & & 2 & & 1 & & & & 1 & & & & & 1 & & & & & & 5 \\
\hline Totals & 8 & 8 & 17 & 42 & 76 & 57 & 58 & 42 & 13 & 10 & 10 & 10 & 22 & 6 & 10 & 9 & 16 & 21 & 15 & 16 & 466 \\
\hline
\end{tabular}


Appendix F. Molluscan taxa weights (g) per XU, Murdumurdu, Square B.

\begin{tabular}{|c|c|c|c|c|c|c|c|c|c|c|}
\hline Taxon & 1 & 2 & 3 & 4 & 5 & 6 & 7 & 8 & 9 & 10 \\
\hline \multicolumn{11}{|l|}{ MARINE BIVALVIA } \\
\hline Arca ventricosa & & 0.02 & & & & & & & & \\
\hline \multicolumn{11}{|l|}{ Asaphis violascens } \\
\hline Beguina semiorbiculata & 0.05 & & & & & & & & & \\
\hline Cardiidea & & & & & & 0.05 & & & 0.01 & \\
\hline \multicolumn{11}{|l|}{ Chama sp. } \\
\hline Circe scripta & & & 0.13 & & 1.02 & 0.10 & & 0.54 & & 0.37 \\
\hline \multicolumn{11}{|l|}{ Corbula fortisulcata } \\
\hline \multicolumn{11}{|l|}{ Glauconome virens } \\
\hline Lunulicardia hemicardium & & & & & & 0.15 & & & & 0.30 \\
\hline Mactra sp. & 0.01 & 0.40 & 0.16 & & & & & & & \\
\hline Marcia hiantina & 15.33 & 27.41 & 51.48 & 179.59 & 354.64 & 236.01 & 387.00 & 194.17 & 31.56 & 9.03 \\
\hline Pinctada sp. & & & & & 2.84 & & & & & \\
\hline Saccostrea glomerata & & & 0.39 & & & & 0.23 & & & \\
\hline Tellina sp. & & & & & & & 0.47 & & 0.43 & \\
\hline \multicolumn{11}{|l|}{ MARINE GASTROPODA } \\
\hline Calliostoma sp. & 0.07 & 0.10 & 0.12 & 0.11 & 0.16 & 0.27 & 0.06 & 0.12 & 0.11 & 0.06 \\
\hline Cerithidea sp. & & & & 0.10 & 0.03 & & & & 0.09 & \\
\hline Clypeomorus sp. & & & & 0.18 & & & & & & \\
\hline \multicolumn{11}{|l|}{ Nassarius sp. } \\
\hline Patellidae & & & & & & & & 0.02 & & \\
\hline Rhinoclavis sp. & & & & 0.01 & & 0.07 & & & & 0.12 \\
\hline Unidentified shell & 13.84 & 14.25 & 25.93 & 27.38 & 27.85 & 27.29 & 31.38 & 33.77 & 33.95 & 25.90 \\
\hline Total & 29.30 & 42.18 & 78.21 & 207.37 & 386.54 & 263.94 & 419.14 & 228.62 & 66.15 & 35.78 \\
\hline
\end{tabular}


Appendix F. Molluscan taxa weights (g) per XU, Murdumurdu, Square B (cont.).

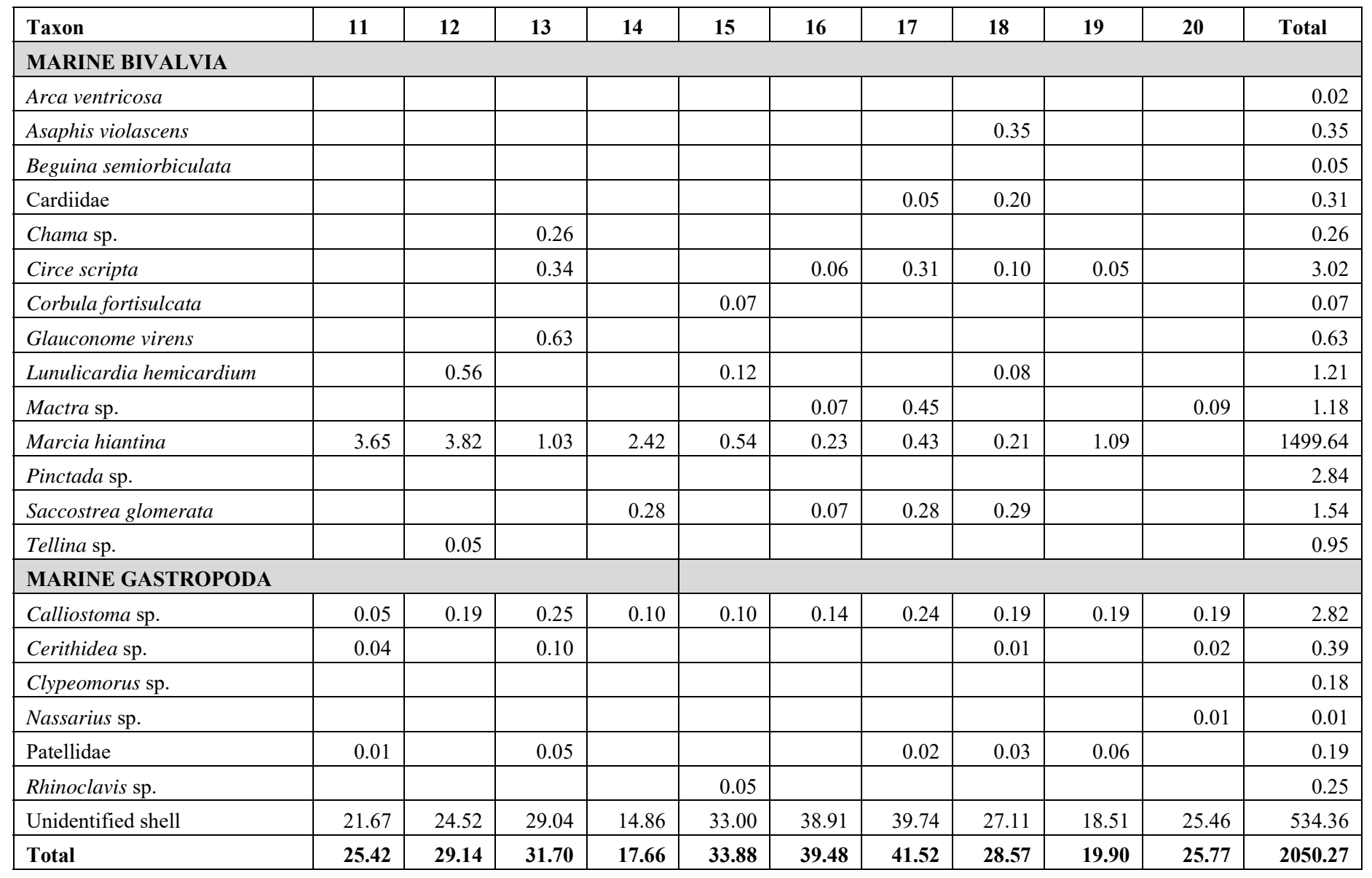


Appendix G. Fish remains, Murdumurdu, Square A. upgp = upper pharyngeal grinding plate. Ipgp $=$ lower pharyngeal grinding plate.

\begin{tabular}{|c|l|l|r|r|r|}
\hline XU & \multicolumn{1}{|c|}{ Taxon } & \multicolumn{1}{|c|}{ Element } & MNI & \multicolumn{1}{c|}{ NISP } & \multicolumn{1}{c|}{ Weight (g) } \\
\hline 1 & Osteichthyes & unidentified & & 5 & 0.0456 \\
\hline 2 & Osteichthyes & unidentified & & 6 & 0.1244 \\
\hline 3 & Osteichthyes & unidentified & & 7 & 0.1195 \\
\hline 3 & Labridae & upgp & 1 & 1 & 0.0697 \\
\hline 4 & Osteichthyes & unidentified & & 8 & 0.2276 \\
\hline 4 & Labridae & upgp & & 1 & 0.1414 \\
\hline 5 & Osteichthyes & unidentified & & 11 & 0.1963 \\
\hline 5 & Lethrinus laticaudis & left otolith & 1 & 1 & 0.0845 \\
\hline 6 & Osteichthyes & unidentified & & 10 & 0.2060 \\
\hline 6 & Labridae & lpgp & & 1 & 0.1333 \\
\hline 7 & Osteichthyes & unidentified & & 1 & 0.0164 \\
\hline 8 & Osteichthyes & unidentified & & 3 & 0.0427 \\
\hline 9 & Osteichthyes & unidentified & & 3 & 0.0380 \\
\hline Total & & & $\mathbf{2}$ & $\mathbf{5 8}$ & $\mathbf{1 . 4 4 5 4}$ \\
\hline
\end{tabular}

Appendix H. Fish remains, Murdumurdu, Square B.

\begin{tabular}{|c|l|l|r|r|r|}
\hline XU & \multicolumn{1}{|c|}{ Taxon } & \multicolumn{1}{|c|}{ Element } & MNI & \multicolumn{1}{c|}{ NISP } & \multicolumn{1}{c|}{ Weight (g) } \\
\hline 1 & Osteichthyes & unidentified & & 1 & 0.0090 \\
\hline 2 & Osteichthyes & unidentified & & 1 & 0.0273 \\
\hline 3 & Osteichthyes & unidentified & & 3 & 0.0318 \\
\hline 4 & Osteichthyes & unidentified & & 3 & 0.0468 \\
\hline 5 & Osteichthyes & unidentified & & 4 & 0.0717 \\
\hline 6 & Osteichthyes & unidentified & & 5 & 0.0857 \\
\hline 6 & Labridae & tooth & 1 & 1 & 0.0248 \\
\hline 7 & Osteichthyes & unidentified & & 2 & 0.0312 \\
\hline 7 & Labridae & teeth & & 2 & 0.0342 \\
\hline 8 & Osteichthyes & unidentified & & 4 & 0.0774 \\
\hline 9 & Osteichthyes & unidentified & & 2 & 0.0099 \\
\hline Total & & & $\mathbf{1}$ & $\mathbf{2 8}$ & $\mathbf{0 . 4 4 9 8}$ \\
\hline
\end{tabular}


Appendix I. Magnetic susceptibility data, Murdumurdu, Square A.

\begin{tabular}{|c|c|c|c|c|c|c|c|}
\hline $\begin{array}{c}\text { Stratigraphic } \\
\text { Unit }\end{array}$ & $\mathbf{X U}$ & $\begin{array}{l}\text { Depth } \\
(\mathrm{cm})\end{array}$ & $\begin{array}{c}\text { Mass } \\
\text { (g) }\end{array}$ & $\begin{array}{c}\text { Mass } \\
\text { Susceptibility } \\
\left(\mathrm{m}^{\wedge} \mathbf{3} / \mathbf{k g}\right) \\
\end{array}$ & $\begin{array}{c}\text { Volume } \\
\text { Susceptibility } \\
\text { (SI) }\end{array}$ & $\begin{array}{c}\text { Frequency } \\
\text { Dependence } \\
(\%)\end{array}$ & $\begin{array}{c}\text { Xlf-Xhf } \\
\text { (X 10-7 m3/kg) }\end{array}$ \\
\hline \multirow{3}{*}{ Ia } & 1 & 5 & 7.43 & $2.67 \mathrm{E}-07$ & $3.84 \mathrm{E}-05$ & 4.13 & $7.92 \mathrm{E}-06$ \\
\hline & 2 & 8 & 6.82 & $2.30 \mathrm{E}-07$ & $3.06 \mathrm{E}-05$ & 5.24 & $7.95 \mathrm{E}-06$ \\
\hline & 3 & 12 & 5.77 & $2.03 \mathrm{E}-07$ & $2.30 \mathrm{E}-05$ & 4.96 & $5.61 \mathrm{E}-06$ \\
\hline \multirow{5}{*}{$\mathrm{Ib}$} & 4 & 17 & 7.13 & $2.24 \mathrm{E}-07$ & $3.11 \mathrm{E}-05$ & 4.95 & 7.64E-06 \\
\hline & 5 & 20 & 6.91 & $3.08 \mathrm{E}-07$ & 4.12E-05 & 4.46 & $9.21 \mathrm{E}-06$ \\
\hline & 6 & 23 & 7.35 & $1.93 \mathrm{E}-07$ & $2.78 \mathrm{E}-05$ & 4.58 & $6.30 \mathrm{E}-06$ \\
\hline & 7 & 26 & 7.21 & $2.11 \mathrm{E}-07$ & 2.97E-05 & 4.47 & $6.58 \mathrm{E}-06$ \\
\hline & 8 & 29 & 7.35 & $1.67 \mathrm{E}-07$ & $2.41 \mathrm{E}-05$ & 3.64 & $4.30 \mathrm{E}-06$ \\
\hline \multirow{12}{*}{ II } & 9 & 32 & 7.88 & $1.36 \mathrm{E}-07$ & $2.12 \mathrm{E}-05$ & 7.37 & $7.65 \mathrm{E}-06$ \\
\hline & 10 & 35 & 6.46 & $6.66 \mathrm{E}-08$ & $9.03 \mathrm{E}-06$ & 7.12 & $2.94 \mathrm{E}-06$ \\
\hline & 11 & 38 & 5.64 & $7.58 \mathrm{E}-08$ & 8.97E-06 & 4.87 & $2.00 \mathrm{E}-06$ \\
\hline & 12 & 41 & 6.10 & $1.11 \mathrm{E}-07$ & $1.37 \mathrm{E}-05$ & 5.10 & $3.33 \mathrm{E}-06$ \\
\hline & 13 & 44 & 7.71 & $1.16 \mathrm{E}-07$ & $1.79 \mathrm{E}-05$ & 4.53 & $3.92 \mathrm{E}-06$ \\
\hline & 14 & 47 & 7.67 & $8.10 \mathrm{E}-08$ & $1.26 \mathrm{E}-05$ & 5.01 & $3.00 \mathrm{E}-06$ \\
\hline & 15 & 50 & 6.96 & 7.07E-08 & $1.02 \mathrm{E}-05$ & 9.05 & $4.28 \mathrm{E}-06$ \\
\hline & 16 & 53 & 7.60 & $1.40 \mathrm{E}-07$ & $2.10 \mathrm{E}-05$ & 3.52 & $3.62 \mathrm{E}-06$ \\
\hline & 17 & 56 & 7.77 & $1.18 \mathrm{E}-07$ & $1.83 \mathrm{E}-05$ & 6.69 & 5.93E-06 \\
\hline & 18 & 59 & 7.54 & $8.37 \mathrm{E}-08$ & $1.28 \mathrm{E}-05$ & 3.24 & $1.97 \mathrm{E}-06$ \\
\hline & 19 & 62 & 7.17 & $1.28 \mathrm{E}-07$ & $1.83 \mathrm{E}-05$ & 3.70 & $3.28 \mathrm{E}-06$ \\
\hline & 20 & 65 & 8.07 & $1.13 \mathrm{E}-07$ & $1.81 \mathrm{E}-05$ & 3.01 & $2.65 \mathrm{E}-06$ \\
\hline
\end{tabular}


Appendix J. Magnetic susceptibility data, Murdumurdu, Square B.

\begin{tabular}{|c|c|c|c|c|c|c|c|}
\hline $\begin{array}{c}\text { Stratigraphic } \\
\text { Unit }\end{array}$ & $\mathbf{X U}$ & $\begin{array}{l}\text { Depth } \\
(\mathrm{cm})\end{array}$ & $\begin{array}{c}\text { Mass } \\
(\mathrm{g})\end{array}$ & $\begin{array}{c}\text { Mass } \\
\text { Susceptibility } \\
\left(\mathrm{m}^{\wedge} \mathbf{3} / \mathbf{k g}\right) \\
\end{array}$ & $\begin{array}{c}\text { Volume } \\
\text { Susceptibility } \\
\text { (SI) }\end{array}$ & $\begin{array}{c}\text { Frequency } \\
\text { Dependence } \\
(\%) \\
\end{array}$ & $\begin{array}{c}\text { Xlf-Xhf } \\
\text { (X 10-7 m3/kg) }\end{array}$ \\
\hline \multirow{2}{*}{ Ia } & 1 & 7 & 7.41 & $2.01 \mathrm{E}-07$ & 2.92E-05 & 5.68 & $8.21 \mathrm{E}-06$ \\
\hline & 2 & 10 & 7.40 & $2.05 \mathrm{E}-07$ & $2.95 \mathrm{E}-05$ & 7.89 & $1.16 \mathrm{E}-05$ \\
\hline \multirow{7}{*}{$\mathrm{Ib}$} & 3 & 13 & 7.29 & $2.68 \mathrm{E}-07$ & $3.79 \mathrm{E}-05$ & 5.21 & $9.87 \mathrm{E}-06$ \\
\hline & 4 & 16 & 7.73 & $2.11 \mathrm{E}-07$ & $3.18 \mathrm{E}-05$ & 6.48 & $1.02 \mathrm{E}-05$ \\
\hline & 5 & 19 & 7.30 & $3.39 \mathrm{E}-07$ & 4.77E-05 & 6.07 & $1.45 \mathrm{E}-05$ \\
\hline & 6 & 22 & 7.38 & $2.25 \mathrm{E}-07$ & $3.23 \mathrm{E}-05$ & 6.79 & $1.09 \mathrm{E}-05$ \\
\hline & 7 & 25 & 6.47 & $1.88 \mathrm{E}-07$ & $2.39 \mathrm{E}-05$ & 3.39 & $3.98 \mathrm{E}-06$ \\
\hline & 8 & 28 & 7.83 & $2.28 \mathrm{E}-07$ & $3.47 \mathrm{E}-05$ & 3.83 & $6.63 \mathrm{E}-06$ \\
\hline & 9 & 31 & 6.90 & $2.27 \mathrm{E}-07$ & $3.05 \mathrm{E}-05$ & 4.58 & $6.93 \mathrm{E}-06$ \\
\hline \multirow{6}{*}{ II } & 10 & 34 & 7.80 & $1.22 \mathrm{E}-07$ & $1.88 \mathrm{E}-05$ & 6.49 & $5.95 \mathrm{E}-06$ \\
\hline & 11 & 37 & 7.25 & $1.47 \mathrm{E}-07$ & $2.10 \mathrm{E}-05$ & 5.78 & $5.95 \mathrm{E}-06$ \\
\hline & 12 & 40 & 7.32 & $1.07 \mathrm{E}-07$ & $1.57 \mathrm{E}-05$ & 6.06 & 4.59E-06 \\
\hline & 13 & 43 & 7.54 & 9.73E-08 & $1.48 \mathrm{E}-05$ & 5.60 & $3.96 \mathrm{E}-06$ \\
\hline & 14 & 46 & 7.70 & $1.08 \mathrm{E}-07$ & $1.66 \mathrm{E}-05$ & 4.50 & $3.62 \mathrm{E}-06$ \\
\hline & 15 & 49 & 7.49 & $1.24 \mathrm{E}-07$ & $1.85 \mathrm{E}-05$ & 4.07 & $3.67 \mathrm{E}-06$ \\
\hline \multirow{4}{*}{ III } & 16 & 52 & 7.57 & $1.55 \mathrm{E}-07$ & $2.31 \mathrm{E}-05$ & 4.05 & 4.59E-06 \\
\hline & 17 & 55 & 7.66 & $1.05 \mathrm{E}-07$ & $1.61 \mathrm{E}-05$ & 5.55 & 4.32E-06 \\
\hline & 18 & 58 & 7.92 & $5.96 \mathrm{E}-08$ & $9.81 \mathrm{E}-06$ & 6.58 & $2.98 \mathrm{E}-06$ \\
\hline & 19 & 60 & 7.22 & $7.85 \mathrm{E}-08$ & $1.16 \mathrm{E}-05$ & 7.91 & $4.32 \mathrm{E}-06$ \\
\hline
\end{tabular}




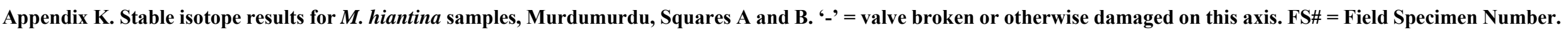

\begin{tabular}{|c|c|c|c|c|c|c|c|c|c|c|}
\hline FS\# & Square & $\mathbf{X U}$ & Species & Valve & $\begin{array}{c}\text { Length } \\
(\mathrm{mm})\end{array}$ & $\begin{array}{c}\text { Height } \\
(\mathrm{mm})\end{array}$ & $\begin{array}{c}\text { Breadth } \\
(\mathrm{mm})\end{array}$ & $\begin{array}{c}\text { Weight } \\
\text { (mg) }\end{array}$ & $\delta^{18} \mathbf{O}_{\text {shell }}(\%)$ & $\delta^{13} C_{\text {shell }}(\%)$ \\
\hline $9-1$ & $\mathrm{~A}$ & 3 & M. hiantina & Left & 35.11 & 27.12 & 9.95 & 3.81 & -1.26 & -1.62 \\
\hline $13-2$ & $\mathrm{~A}$ & 4 & M. hiantina & Right & 36.24 & 26.46 & 9.84 & 3.53 & -1.15 & -1.10 \\
\hline $13-3$ & $\mathrm{~A}$ & 4 & M. hiantina & Right & 37.40 & 27.39 & 9.87 & 3.37 & -1.19 & -1.74 \\
\hline $13-4$ & $\mathrm{~A}$ & 4 & M. hiantina & Right & 35.69 & 26.91 & 9.78 & 2.68 & -0.89 & -1.03 \\
\hline $17-2$ & $\mathrm{~A}$ & 5 & M. hiantina & Right & 32.54 & 23.74 & 7.96 & 2.64 & -0.70 & -1.07 \\
\hline $17-3$ & $\mathrm{~A}$ & 5 & M. hiantina & Right & 36.57 & 27.73 & 9.79 & 3.01 & -2.14 & -2.38 \\
\hline $17-4$ & $\mathrm{~A}$ & 5 & M. hiantina & Left & 33.40 & 26.38 & 9.23 & 3.23 & -0.21 & 0.90 \\
\hline $17-5$ & $\mathrm{~A}$ & 5 & M. hiantina & Right & 36.37 & 26.92 & 10.08 & 3.79 & -2.29 & -0.17 \\
\hline $21-1$ & $\mathrm{~A}$ & 6 & M. hiantina & Right & 35.56 & 26.62 & 9.41 & 3.40 & -1.07 & -1.85 \\
\hline $37-1$ & A & 10 & M. hiantina & Left & - & 28.74 & 10.05 & 2.92 & -0.65 & -1.43 \\
\hline $7-1$ & $\mathrm{~B}$ & 2 & M. hiantina & Right & 33.34 & 25.35 & 8.90 & 2.70 & -0.94 & -2.18 \\
\hline $15-1$ & $\mathrm{~B}$ & 4 & M. hiantina & Left & 33.24 & 24.98 & 8.02 & 2.37 & -0.93 & 0.09 \\
\hline $15-2$ & $\mathrm{~B}$ & 4 & M. hiantina & Left & 35.87 & 26.78 & 9.57 & 3.37 & -1.00 & -1.75 \\
\hline $19-1$ & $\mathrm{~B}$ & 5 & M. hiantina & Right & 32.37 & 24.01 & 8.22 & 2.17 & -1.15 & -1.59 \\
\hline $19-2$ & B & 5 & M. hiantina & Left & 36.22 & 28.02 & 9.88 & 3.19 & -2.19 & -2.78 \\
\hline $19-3$ & $\mathrm{~B}$ & 5 & M. hiantina & Left & 33.00 & 26.21 & 9.36 & 3.02 & -1.87 & 0.05 \\
\hline $19-4$ & $\mathrm{~B}$ & 5 & M. hiantina & Right & 38.30 & 29.64 & 10.08 & 4.49 & -1.90 & 0.02 \\
\hline $23-1$ & $\mathrm{~B}$ & 6 & M. hiantina & Right & 32.16 & 25.30 & 8.77 & 2.58 & -2.19 & -0.31 \\
\hline $23-2$ & $\mathrm{~B}$ & 6 & M. hiantina & Right & 34.97 & 28.42 & 9.60 & 3.44 & -2.57 & -0.37 \\
\hline
\end{tabular}


Appendix L. Field specimen log, Murdumurdu, Squares A and B.

\begin{tabular}{|c|c|c|c|c|c|}
\hline FS\# & Square & $\mathbf{X U}$ & Description & Date & \# of Bags \\
\hline 1 & $\mathrm{~A}$ & 1 & $2.3 \mathrm{~mm}$ sieve residue & $13 / 07 / 12$ & 1 \\
\hline 2 & $\mathrm{~A}$ & 1 & Sediment sample & $13 / 07 / 12$ & 1 \\
\hline 3 & $\mathrm{~B}$ & 1 & $2.3 \mathrm{~mm}$ sieve residue & $13 / 07 / 12$ & 1 \\
\hline 4 & $\mathrm{~B}$ & 1 & Sediment sample & $13 / 07 / 12$ & 1 \\
\hline 5 & $\mathrm{~A}$ & 2 & $2.3 \mathrm{~mm}$ sieve residue & $13 / 07 / 12$ & 1 \\
\hline 6 & $\mathrm{~A}$ & 2 & Sediment sample & $13 / 07 / 12$ & 1 \\
\hline 7 & $\mathrm{~B}$ & 2 & $2.3 \mathrm{~mm}$ sieve residue & $13 / 07 / 12$ & 1 \\
\hline 8 & $\mathrm{~B}$ & 2 & Sediment sample & $13 / 07 / 12$ & 1 \\
\hline 9 & $\mathrm{~A}$ & 3 & $2.3 \mathrm{~mm}$ sieve residue & $13 / 07 / 12$ & 1 \\
\hline 10 & $\mathrm{~A}$ & 3 & Sediment sample & $13 / 07 / 12$ & 1 \\
\hline 11 & $\mathrm{~B}$ & 3 & $2.3 \mathrm{~mm}$ sieve residue & $13 / 07 / 12$ & 1 \\
\hline 12 & $\mathrm{~B}$ & 3 & Sediment sample & $13 / 07 / 12$ & 1 \\
\hline 13 & $\mathrm{~A}$ & 4 & $2.3 \mathrm{~mm}$ sieve residue & $13 / 07 / 12$ & 1 \\
\hline 14 & $\mathrm{~A}$ & 4 & Sediment sample & $13 / 07 / 12$ & 1 \\
\hline 15 & $\mathrm{~B}$ & 4 & $2.3 \mathrm{~mm}$ sieve residue & $13 / 07 / 12$ & 1 \\
\hline 16 & $\mathrm{~B}$ & 4 & Sediment sample & $13 / 07 / 12$ & 1 \\
\hline 17 & $\mathrm{~A}$ & 5 & $2.3 \mathrm{~mm}$ sieve residue & $13 / 07 / 12$ & 1 \\
\hline 18 & $\mathrm{~A}$ & 5 & Sediment sample & $13 / 07 / 12$ & 1 \\
\hline 19 & $\mathrm{~B}$ & 5 & $2.3 \mathrm{~mm}$ sieve residue & $13 / 07 / 12$ & 1 \\
\hline 20 & $\mathrm{~B}$ & 5 & Sediment sample & $13 / 07 / 12$ & 1 \\
\hline 21 & $\mathrm{~A}$ & 6 & $2.3 \mathrm{~mm}$ sieve residue & $13 / 07 / 12$ & 1 \\
\hline 22 & A & 6 & Sediment sample & $13 / 07 / 12$ & 1 \\
\hline 23 & $\mathrm{~B}$ & 6 & $2.3 \mathrm{~mm}$ sieve residue & $13 / 07 / 12$ & 1 \\
\hline 24 & $\mathrm{~B}$ & 6 & Sediment sample & $13 / 07 / 12$ & 1 \\
\hline 25 & A & 7 & $2.3 \mathrm{~mm}$ sieve residue & $13 / 07 / 12$ & 1 \\
\hline 26 & $\mathrm{~A}$ & 7 & Sediment sample & $13 / 07 / 12$ & 1 \\
\hline 27 & $\mathrm{~B}$ & 7 & $2.3 \mathrm{~mm}$ sieve residue & $13 / 07 / 12$ & 1 \\
\hline 28 & $\mathrm{~B}$ & 7 & Sediment sample & $13 / 07 / 12$ & 1 \\
\hline 29 & $\mathrm{~A}$ & 8 & $2.3 \mathrm{~mm}$ sieve residue & $13 / 07 / 12$ & 1 \\
\hline 30 & A & 8 & Sediment sample & $13 / 07 / 12$ & 1 \\
\hline 31 & $\mathrm{~B}$ & 8 & $2.3 \mathrm{~mm}$ sieve residue & $13 / 07 / 12$ & 1 \\
\hline 32 & $\mathrm{~B}$ & 8 & Sediment sample & $13 / 07 / 12$ & 1 \\
\hline 33 & $\mathrm{~A}$ & 9 & $2.3 \mathrm{~mm}$ sieve residue & $13 / 07 / 12$ & 1 \\
\hline 34 & $\mathrm{~A}$ & 9 & Sediment sample & $13 / 07 / 12$ & 1 \\
\hline 35 & $\mathrm{~B}$ & 9 & $2.3 \mathrm{~mm}$ sieve residue & $14 / 07 / 12$ & 1 \\
\hline 36 & $\mathrm{~B}$ & 9 & Sediment sample & $14 / 07 / 12$ & 1 \\
\hline 37 & $\mathrm{~A}$ & 10 & $2.3 \mathrm{~mm}$ sieve residue & $13 / 07 / 12$ & 1 \\
\hline 38 & $\mathrm{~A}$ & 10 & Sediment sample & $13 / 07 / 12$ & 1 \\
\hline 39 & $\mathrm{~B}$ & 10 & $2.3 \mathrm{~mm}$ sieve residue & $14 / 07 / 12$ & 1 \\
\hline 40 & $\mathrm{~B}$ & 10 & Sediment sample & $14 / 07 / 12$ & 1 \\
\hline 41 & $\mathrm{~A}$ & 11 & $2.3 \mathrm{~mm}$ sieve residue & $13 / 07 / 12$ & 1 \\
\hline 42 & $\mathrm{~A}$ & 11 & Sediment sample & $13 / 07 / 12$ & 1 \\
\hline 43 & $\mathrm{~B}$ & 11 & $2.3 \mathrm{~mm}$ sieve residue & $14 / 07 / 12$ & 1 \\
\hline 44 & $\mathrm{~B}$ & 11 & Sediment sample & $14 / 07 / 12$ & 1 \\
\hline 45 & $\mathrm{~A}$ & 12 & $2.3 \mathrm{~mm}$ sieve residue & $14 / 07 / 12$ & 1 \\
\hline 46 & $\mathrm{~A}$ & 12 & Sediment sample & $14 / 07 / 12$ & 1 \\
\hline 47 & $\mathrm{~B}$ & 12 & $2.3 \mathrm{~mm}$ sieve residue & $14 / 07 / 12$ & 1 \\
\hline 48 & $\mathrm{~B}$ & 12 & Sediment sample & $14 / 07 / 12$ & 1 \\
\hline
\end{tabular}


Appendix L. Field specimen log, Murdumurdu, Squares A and B (cont.).

\begin{tabular}{|c|c|c|c|c|c|}
\hline FS\# & Square & $\mathbf{X U}$ & Description & Date & \# of Bags \\
\hline 49 & $\mathrm{~A}$ & 13 & $2.3 \mathrm{~mm}$ sieve residue & $14 / 07 / 12$ & 1 \\
\hline 50 & $\mathrm{~A}$ & 13 & Sediment sample & $14 / 07 / 12$ & 1 \\
\hline 51 & $\mathrm{~B}$ & 13 & $2.3 \mathrm{~mm}$ sieve residue & $14 / 07 / 12$ & 1 \\
\hline 52 & $\mathrm{~B}$ & 13 & Sediment sample & $14 / 07 / 12$ & 1 \\
\hline 53 & $\mathrm{~A}$ & 14 & $2.3 \mathrm{~mm}$ sieve residue & $14 / 07 / 12$ & 1 \\
\hline 54 & $\mathrm{~A}$ & 14 & Sediment sample & $14 / 07 / 12$ & 1 \\
\hline 55 & $\mathrm{~B}$ & 14 & $2.3 \mathrm{~mm}$ sieve residue & $14 / 07 / 12$ & 1 \\
\hline 56 & $\mathrm{~B}$ & 14 & Sediment sample & $14 / 07 / 12$ & 1 \\
\hline 57 & $\mathrm{~A}$ & 15 & $2.3 \mathrm{~mm}$ sieve residue & $14 / 07 / 12$ & 1 \\
\hline 58 & $\mathrm{~A}$ & 15 & Sediment sample & $14 / 07 / 12$ & 1 \\
\hline 59 & $\mathrm{~B}$ & 15 & $2.3 \mathrm{~mm}$ sieve residue & $14 / 07 / 12$ & 1 \\
\hline 60 & $\mathrm{~B}$ & 15 & Sediment sample & $14 / 07 / 12$ & 1 \\
\hline 61 & $\mathrm{~A}$ & 16 & $2.3 \mathrm{~mm}$ sieve residue & $14 / 07 / 12$ & 1 \\
\hline 62 & A & 16 & Sediment sample & $14 / 07 / 12$ & 1 \\
\hline 63 & $\mathrm{~B}$ & 16 & $2.3 \mathrm{~mm}$ sieve residue & $14 / 07 / 12$ & 1 \\
\hline 64 & $\mathrm{~B}$ & 16 & Sediment sample & $14 / 07 / 12$ & 1 \\
\hline 65 & A & 17 & $2.3 \mathrm{~mm}$ sieve residue & $14 / 07 / 12$ & 1 \\
\hline 66 & $\mathrm{~A}$ & 17 & Sediment sample & $14 / 07 / 12$ & 1 \\
\hline 67 & $\mathrm{~B}$ & 17 & $2.3 \mathrm{~mm}$ sieve residue & $14 / 07 / 12$ & 1 \\
\hline 68 & $\mathrm{~B}$ & 17 & Sediment sample & $14 / 07 / 12$ & 1 \\
\hline 69 & $\mathrm{~A}$ & 18 & $2.3 \mathrm{~mm}$ sieve residue & $14 / 07 / 12$ & 1 \\
\hline 70 & $\mathrm{~A}$ & 18 & Sediment sample & $14 / 07 / 12$ & 1 \\
\hline 71 & $\mathrm{~B}$ & 18 & $2.3 \mathrm{~mm}$ sieve residue & $14 / 07 / 12$ & 1 \\
\hline 72 & $\mathrm{~B}$ & 18 & Sediment sample & $14 / 07 / 12$ & 1 \\
\hline 73 & A & 19 & $2.3 \mathrm{~mm}$ sieve residue & $14 / 07 / 12$ & 1 \\
\hline 74 & $\mathrm{~A}$ & 19 & Sediment sample & $14 / 07 / 12$ & 1 \\
\hline 75 & $\mathrm{~B}$ & 19 & $2.3 \mathrm{~mm}$ sieve residue & $14 / 07 / 12$ & 1 \\
\hline 76 & $\mathrm{~B}$ & 19 & Sediment sample & $14 / 07 / 12$ & 1 \\
\hline 77 & $\mathrm{~A}$ & 20 & $2.3 \mathrm{~mm}$ sieve residue & $14 / 07 / 12$ & 1 \\
\hline 78 & A & 20 & Sediment sample & $14 / 07 / 12$ & 1 \\
\hline 79 & $\mathrm{~B}$ & 20 & $2.3 \mathrm{~mm}$ sieve residue & $14 / 07 / 12$ & 1 \\
\hline 80 & $\mathrm{~B}$ & 20 & Sediment sample & $14 / 07 / 12$ & 1 \\
\hline 81 & $\mathrm{~A}$ & - & East section 14C samples collection & $14 / 07 / 12$ & 1 \\
\hline 82 & $\mathrm{~B}$ & - & East section $14 \mathrm{C}$ samples collection & $14 / 07 / 12$ & 1 \\
\hline 83 & $\mathrm{~A}$ & - & Magnetic susceptibility sample $5 \mathrm{~cm}$ & $14 / 07 / 12$ & 1 \\
\hline 84 & A & - & Magnetic susceptibility sample $8 \mathrm{~cm}$ & $14 / 07 / 12$ & 1 \\
\hline 85 & $\mathrm{~A}$ & - & Magnetic susceptibility sample $12 \mathrm{~cm}$ & $14 / 07 / 12$ & 1 \\
\hline 86 & $\mathrm{~A}$ & - & Magnetic susceptibility sample $17 \mathrm{~cm}$ & $14 / 07 / 12$ & 1 \\
\hline 87 & A & - & Magnetic susceptibility sample $20 \mathrm{~cm}$ & $14 / 07 / 12$ & 1 \\
\hline 88 & $\mathrm{~A}$ & - & Magnetic susceptibility sample $23 \mathrm{~cm}$ & $14 / 07 / 12$ & 1 \\
\hline 89 & $\mathrm{~A}$ & - & Magnetic susceptibility sample $26 \mathrm{~cm}$ & $14 / 07 / 12$ & 1 \\
\hline 90 & $\mathrm{~A}$ & - & Magnetic susceptibility sample $29 \mathrm{~cm}$ & $14 / 07 / 12$ & 1 \\
\hline 91 & $\mathrm{~A}$ & - & Magnetic susceptibility sample $32 \mathrm{~cm}$ & $14 / 07 / 12$ & 1 \\
\hline 92 & A & - & Magnetic susceptibility sample $35 \mathrm{~cm}$ & $14 / 07 / 12$ & 1 \\
\hline 93 & $\mathrm{~A}$ & - & Magnetic susceptibility sample $38 \mathrm{~cm}$ & $14 / 07 / 12$ & 1 \\
\hline 94 & $\mathrm{~A}$ & - & Magnetic susceptibility sample $41 \mathrm{~cm}$ & $14 / 07 / 12$ & 1 \\
\hline 95 & A & - & Magnetic susceptibility sample $44 \mathrm{~cm}$ & $14 / 07 / 12$ & 1 \\
\hline 96 & $\mathrm{~A}$ & - & Magnetic susceptibility sample $47 \mathrm{~cm}$ & $14 / 07 / 12$ & 1 \\
\hline
\end{tabular}


Appendix L. Field specimen log, Murdumurdu, Squares A and B (cont.).

\begin{tabular}{|c|c|c|l|c|c|}
\hline FS\# & Square & XU & \multicolumn{1}{|c|}{ Description } & Date & \# of Bags \\
\hline 97 & A & - & Magnetic susceptibility sample $50 \mathrm{~cm}$ & $14 / 07 / 12$ & 1 \\
\hline 98 & A & - & Magnetic susceptibility sample $53 \mathrm{~cm}$ & $14 / 07 / 12$ & 1 \\
\hline 99 & A & - & Magnetic susceptibility sample $56 \mathrm{~cm}$ & $14 / 07 / 12$ & 1 \\
\hline 100 & A & - & Magnetic susceptibility sample $59 \mathrm{~cm}$ & $14 / 07 / 12$ & 1 \\
\hline 101 & A & - & Magnetic susceptibility sample $62 \mathrm{~cm}$ & $14 / 07 / 12$ & 1 \\
\hline 102 & A & - & Magnetic susceptibility sample $65 \mathrm{~cm}$ & $14 / 07 / 12$ & 1 \\
\hline 103 & B & - & Magnetic susceptibility sample $7 \mathrm{~cm}$ & $14 / 07 / 12$ & 1 \\
\hline 104 & B & - & Magnetic susceptibility sample $10 \mathrm{~cm}$ & $14 / 07 / 12$ & 1 \\
\hline 105 & B & - & Magnetic susceptibility sample $13 \mathrm{~cm}$ & $14 / 07 / 12$ & 1 \\
\hline 106 & B & - & Magnetic susceptibility sample $16 \mathrm{~cm}$ & $14 / 07 / 12$ & 1 \\
\hline 107 & B & - & Magnetic susceptibility sample $19 \mathrm{~cm}$ & $14 / 07 / 12$ & 1 \\
\hline 108 & B & - & Magnetic susceptibility sample $22 \mathrm{~cm}$ & $14 / 07 / 12$ & 1 \\
\hline 109 & B & - & Magnetic susceptibility sample $25 \mathrm{~cm}$ & $14 / 07 / 12$ & 1 \\
\hline 110 & B & - & Magnetic susceptibility sample $28 \mathrm{~cm}$ & $14 / 07 / 12$ & 1 \\
\hline 111 & B & - & Magnetic susceptibility sample $31 \mathrm{~cm}$ & $14 / 07 / 12$ & 1 \\
\hline 112 & B & - & Magnetic susceptibility sample $34 \mathrm{~cm}$ & $14 / 07 / 12$ & 1 \\
\hline 113 & B & - & Magnetic susceptibility sample $37 \mathrm{~cm}$ & $14 / 07 / 12$ & 1 \\
\hline 114 & B & - & Magnetic susceptibility sample $40 \mathrm{~cm}$ & $14 / 07 / 12$ & 1 \\
\hline 115 & B & - & Magnetic susceptibility sample $43 \mathrm{~cm}$ & $14 / 07 / 12$ & 1 \\
\hline 116 & B & - & Magnetic susceptibility sample $46 \mathrm{~cm}$ & $14 / 07 / 12$ & 1 \\
\hline 117 & B & - & Magnetic susceptibility sample $49 \mathrm{~cm}$ & $14 / 07 / 12$ & 1 \\
\hline 118 & B & - & Magnetic susceptibility sample $52 \mathrm{~cm}$ & $14 / 07 / 12$ & 1 \\
\hline 119 & B & - & Magnetic susceptibility sample $55 \mathrm{~cm}$ & $14 / 07 / 12$ & 1 \\
\hline 120 & B & - & Magnetic susceptibility sample $58 \mathrm{~cm}$ & $14 / 07 / 12$ & 1 \\
\hline 121 & B & - & Magnetic susceptibility sample $60 \mathrm{~cm}$ & $14 / 07 / 12$ & 1 \\
\hline
\end{tabular}

